\title{
PROPERTIES OF CARBONS DERIVED FROM ACENAPHTHYLENE AND CINNAMYLIDENEINDENE
}

O. J. Horne

W. E. Smith

B. Napier 


\section{DISCLAIMER}

This report was prepared as an account of work sponsored by an agency of the United States Government. Neither the United States Government nor any agency Thereof, nor any of their employees, makes any warranty, express or implied, or assumes any legal liability or responsibility for the accuracy, completeness, or usefulness of any information, apparatus, product, or process disclosed, or represents that its use would not infringe privately owned rights. Reference herein to any specific commercial product, process, or service by trade name, trademark, manufacturer, or otherwise does not necessarily constitute or imply its endorsement, recommendation, or favoring by the United States Government or any agency thereof. The views and opinions of authors expressed herein do not necessarily state or reflect those of the United States Government or any agency thereof. 


\section{DISCLAIMER}

Portions of this document may be illegible in electronic image products. Images are produced from the best available original document. 
Reference to a company or product name does not imply approval or recommendation of the product by Union Carbide Corporation or the U.S. Atomic Energy Commission to the exclusion of others that may meet specifications.

Printed in the United States of America. Available from

National Technical Information Service

U.S. Department of Commerce

5285 Port Royal Road, Springfield, Virginia 22151

Price: Printed Copy $\$ 4.00$; Microfiche $\$ 1.45$

This report was prepared as an account of work sponsored by the United States Government. Neither the United States nor the United States Atomic Energy Commission, nor any of their employees, nor any of their contractors, subcontractors, or their employees, makes any warranty, express or implied, or assumes any legal liability or responsibility for the accuracy, completeness or usefulness of any information, apparatus, product or process disclosed, or represents that its use would not infringe privately owned rights. 


\title{
PROPERTIES OF CARBONS DERIVED FROM ACENAPHTHYLENE AND CINNAMYLIDENEINDENE
}

\author{
O. J. Horne \\ W. E. Smith \\ B. Napier
}

Oak Ridge Y-12 Plant

P.O. Box Y, Oak Ridge, Tennessee 37830

Date Issued - December 7, 1973

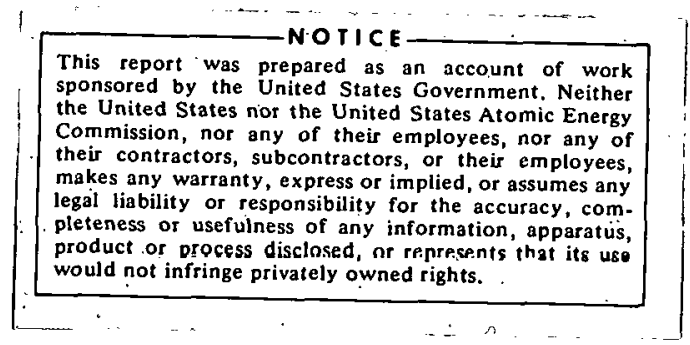

Prepared for the U.S. Alomic Energy Commission Under U.S. Government Contract W.7405eng-26

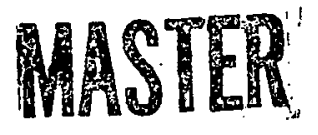




\section{ABSTRACT}

The effect of temperature and various additives on the properties of acenaphthylene (ACN) and cinnamylideneindene (CAI), and carbons derived from ACN and CAI, were studied. In thermal studies, a CAI polymer was found to be relatively stable for extended periods at $250^{\circ} \mathrm{C}$, while significant property changes were noted for an ACN polymer under the same conditions. By blending various additives with $\mathrm{ACN}$ and $\mathrm{CAl}$ prior to pyrolysis, a wide variety of carbon properties were obtained, thus affording avenues to control these properties by modifying the precursors. 


\section{CONTENTS}

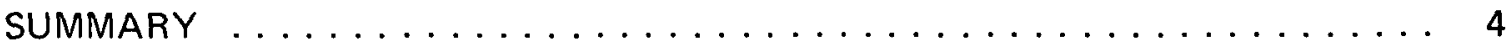

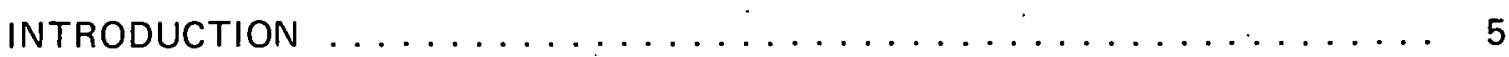

CARBONS FROM ACENAPHTHYLENE AND CINNAMYLIDENEINDENE $\ldots \ldots \ldots 6$

Materials .............................. 6

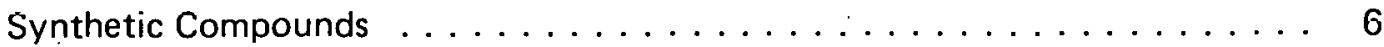

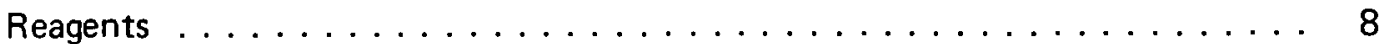

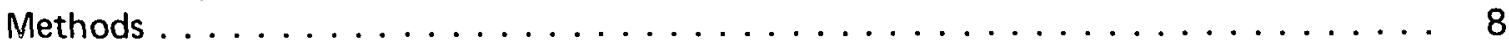

Polymer Properties $\ldots \ldots \ldots \ldots \ldots \ldots \ldots \ldots \ldots \ldots \ldots$

Carbon Properties ....................... 9

Study of Acenaphthylene and Cinnamylideneindene $\ldots \ldots \ldots \ldots \ldots \ldots$

Properties of Acenaphthylene and Cinnamylideneindene Polymers as Functions of the Heat-Treatment Time at $250^{\circ} \mathrm{C} \ldots \ldots . \ldots 9$

Properties of Carbons Derived from Acenaphthylene and Cinnamylideneindene as Functions of Temperature . . . . . . . . . 10

Properties of Carbonns. Derived from Blends of Acenaphthylene with Pyromellitic Dianhydride . . . . . . . . . . . . . 18

Properties of Carbons Derived from Blends of Acenaphthylene and Cinnamylideneindene with Furfurylideneindene $\ldots \ldots \ldots 18$

Properties of Carbons Derived from Blends of Acenaphthylene and Cinnamylideneindene with $\mathrm{p}$-Xylylideneindene . . . . . . 32

Properties of Carbons Derived from Blends of Acenaphthylene and Cinnamylideneindene with Isotruxene . . . . . . . . 35

Conclusions ............................ 43

REFERENCES $\ldots \ldots \ldots \ldots \ldots \ldots \ldots \ldots \ldots \ldots \ldots \ldots \ldots \ldots$

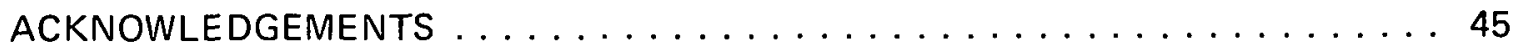




\section{SUMMARY}

The primary goal of this study was to evaluate the properties of carbons derived from acenaphthylene (ACN) and cinnamylideneindene (CAI). Included in this study were: (1) an evaluation of the thermal stability of CAl and ACN polymers at $250^{\circ} \mathrm{C}$; (2) a determination of the properties of carbon derived from $C A I$ and $A C N$ over the temperature range from 1,000 to $2,800^{\circ} \mathrm{C}$; and (3) an evaluation of various additives to $A C N$ and $C A I$ by correlating the properties of the derived carbon with the additive type and content.

The primary conclusions reached from this study were: (1) the CAl polymer was relatively stable at $250^{\circ} \mathrm{C}$ for up to 28 days, while the $\mathrm{ACN}$ polymer showed some variation in physical properties during heating at $250^{\circ} \mathrm{C}$ for 28 days; (2) $\mathrm{ACN}$ and $\mathrm{CAl}$ produce carbons that densify at approximately 1,500 and $2,000^{\circ} \mathrm{C}$, respectively, and undergo significant three-dimensional ordering between 2,000 and $2,800^{\circ} \mathrm{C}$ to yield highly crystalline carbons; and (3) properties of carbon derived from $\mathrm{ACN}$ and $\mathrm{CAl}$ can be modified over a wide range by blending additives with the respective materials prior to pyrolysis. 


\section{INTRODUCTION}

Carbon has properties which are quite adaptable to demands brought by reactor, aerospace, and related technologies for specialty forms of structural materials. These properties include: (1) high-temperature heat resistance, (2) resistance to chemical attack, (3) constancy of properties with time, (4) a high strength-to-density ratio, and (5) a variety of forms into which the material can conveniently be made and the variety of properties that these forms can impact in structural applications.

As is characteristic of ceramic materials, properties of carbon are a function of microstructure (ie, crystal size, shape, and orientation). Carbon has versatility in that its crystallinity ranges from essentially amorphous to a well-ordered structure characteristic of natural flake graphite. Thus, control of carbon properties can be achieved by control of the crystalline parameters of size, shape, and orientation.

In general, organic materials which are infusible or become infusible prior to pyrolysis do not tend to produce graphitic carbon. This type of material is characterized by thermnsetting resins or highly crosslinked polymers. On the other hand, thermoplastic materials or materials with a low degree of crosslinking provide viscosities that are conducive to molecular rearrangement and reorientation prior to pyrolysis; and, thus, tend to form graphitic carbon unless stable, nonplanar intermediates are formed.

Efforts in this study at the Oak Ridge Y-12 Plant(a) are directed toward correlations between the precursor properties and the properties of a derived carbon. By knowing the relation between precursor properties and precursor-derived carbon properties, control over the latter may be exercised. This control involves two aspects: (1) reproducibility, with emphasis on the use of synthetic raw materials as carbon precursors; (2) manipulative control, which would make it possible to make carbon with specific and preselected properties by the appropriate choice of precursors and processing conditions.

This report describes an evaluation of the properties of two synthetic precursorscinnamylideneindene (CAI) and acenaphthylene (ACN). Properties of carbons derived from these two materials, as well as properties of carbons derived from blends of CAI and ACN with various additives, were determined in an effort to correlate the precursor properties with the properties of the derived carbons.

(a) Operated by Union Carbide Corporation's Nuclear Division for the US Atomic Energy Commission. 


\section{CARBONS FROM ACENAPHTHYLENE AND CINNAMYLIDENEINDENE}

\section{MATERIALS}

\section{Synthetic Compounds}

Acenaphythylene (ACN) was obtained from usual chemical supply sources. Upon carbonization and subsequent graphitization, $\mathrm{ACN}$ :

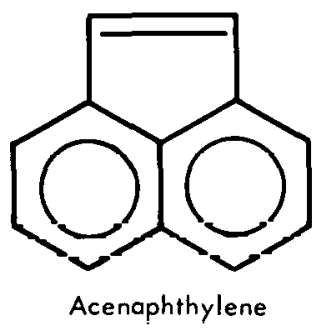

yields a highly graphitic carbon.

Cinnamylideneindene (CAIl) was prepared by the room-temperature condensation of indene with cinnamaldehyde in the presence of an alcoholic base. (1) The structure of CAI is:

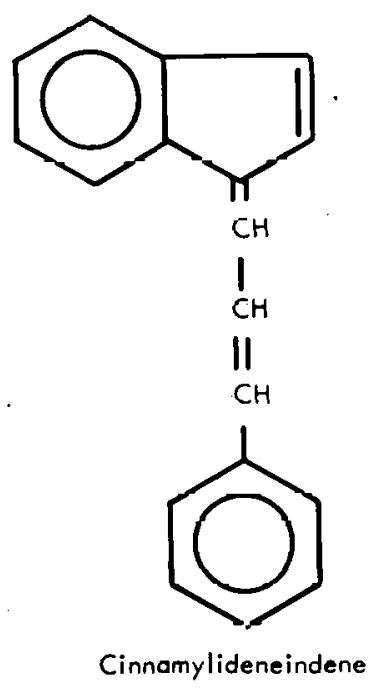

Since earlier studies have indicated that some inorganic substituents (ie, residual potassium hydroxide) have an effect on the properties of CAI-derived carbon, $(2)$ efforts were made to use CAI with a minimum inorganic contaminant. The CAI used in this study contained less than $100 \mathrm{ppm}$ potassium, as analyzed by $X$-ray fluorescence spectroscopy. Carbon derived from this $\mathrm{CAl}$ is highly graphitic. 
Isotruxene (ITX):

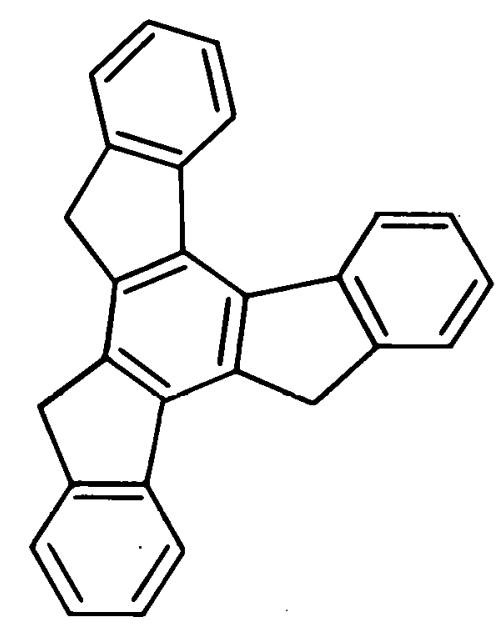

Isotruxene

was prepared by the reaction of indene and 1,4-naphthoquinone in the presence of a tertiary amine. (1) Properties of carbon derived from IT.X correspond to those of a fine-grain, isotropic carbon with a low order of graphiticity.

The synthesis of $p$-xylylideneindene (XYN) was accomplished by the room-temperature reaction of indene with terephthalaldehyde in the presence of an alcoholic base. (1) The structure of $X Y N$ shows a highly conjugated system of unsaturated bonding:

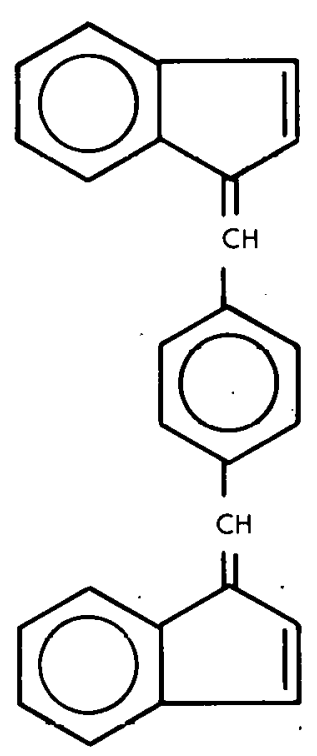

p-Xylylidene indene

Upon carbonization and subsequent graphitization, a noncrystalline carbon is obtained from XYN. 
Furfurylideneindene (FAI):

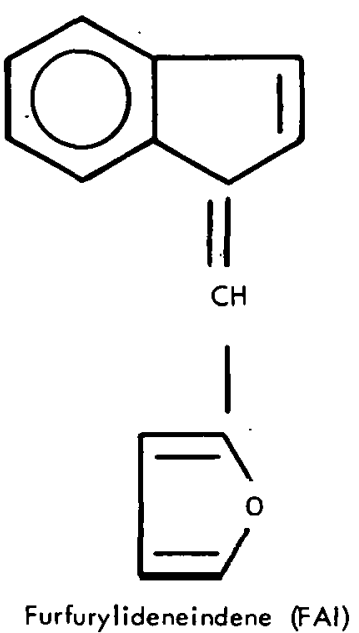

was prepared by the room-temperature condensation of indene and furfural in the presence of an alcoholic base. ${ }^{(3)}$ Carbon derived from FAl is noncrystalline.

\section{Reägents}

Pyromellitic dianhydride was obtained from the usual chemical supply sources and used as received.

\section{METHODS}

\section{Polymer Properties}

Polymers examined in this study were prepared by. one of two methods: (1) heating approximately two kılograms of the specified material in a stainless steel beaker under a slight flow of argon, with heating times ranging from 7 to 28 days; or (2) autoclaving the respective blends in a gas pressure autoclave for two hours at 300 or $340^{\circ} \mathrm{C}$ in nitrogen at an initial (room-temperature) pressure of 300 psi.

Polymer average molecular weight data were obtained with a Hewlett-Packard high-temperature vapor pressure osmometer (Model 302), using succose octaacetate as the calibration standard.

Gel permeation chromatographic (GPC) scans were obtained from a Waters Associates Model 200 gel permeation chromatograph. The polymers were dissolved in reagent-grade tetrahydrofuran and eluted on a column packed with Styrogel, a styrene-divinylbenzene polymer supplied by Waters Associates.

Pitch softening points, benzene insolubles, and Conradson carbon residues were determined according to ASTM D-36-66, ASTM D-2317, and ASTM D-189-65, respectively, while oxygen contents were determined by neutron activation. 


\section{Carbon Properties}

Carbonization consisted of heating $\mathbf{3 0}$ grams of the precursors or precursor blends (prepared using a Waring blender) in a three-inch-diameter crucible to $1,000^{\circ} \mathrm{C}$ under an inert gas atmosphere. This procedure was rate controlled and required approximately 60 hours. Other samples containing 200 grams of precursor powders were heated in four-inch-diameter stainless steel beakers. Coke yields were calculated as the percent residue after the $1,000^{\circ} \mathrm{C}$ carbonization step. Some of the samples received a precarbonization air cure, which consisted of heating the samples in air to $250^{\circ} \mathrm{C}$ using a programmed heating cycle covering a period of approximately 50 hours. After the air cure, the samples were carbonized in 30 -gram batches, as described previously.

Helium densities were calculated by determining the volume of weighed sapples by the displacement of helium.

Metallographic samples were mounted in epoxy resin and placed under vacuum to remove adherent air bubbles and to impregnate the flakes. The mounted specimens were then ground successively on silicon carbide grits of 240,320,400, and 600 size. After cleaning to remove loose adherent silicon carbide, the samples were polished with Linde $A 10.3$ micrometer $\mathrm{Al}_{2} \mathrm{O}_{3}$ powder), suspended in water on Pellon cloth on a Syntron vibrating polisher. This work was followed by a final polish on the Syntron with Gamel cloth and a water suspension of Linde $\mathrm{B}\left(0.05\right.$ micrometer $\mathrm{Al}_{2} \mathrm{O}_{3}$ powder). The samples were then cleaned in flowing water with a cotton swab and blown dry with compressed air. Photomicrographs were made using sensitive-tint illumination on a Bausch and Lomb Research 1 metallograph.

A Siemen's Crystalloflex IV recording diffractometer with copper $\mathrm{K}_{a}$ radiation was used to obtain the $X$-ray diffraction data. An internal standard of sodium chloride was analyzed with each sample. Interlayer spacings were calculated from the $X$-ray data using the methods described by Ruland. (4) The degree of graphiticity of the carbons was also expressed in terms of a $\mathrm{g}$ factor defined as follows by Maire and Mering: (5)

$$
d_{002}=g(3.355)+(1-g) 3.44 \text {. }
$$

\section{STUDY OF ACENAPHTHYLENE AND CINNAMYLIDENEINDENE}

\section{Properties of Acenaphthylene and Cinnamylideneindene Polymers as Functions of the Heat-Treatment Time at $250^{\circ} \mathrm{C}$}

Baking formed pieces to $750-900^{\circ} \mathrm{C}$ is accompanied by a loss of some of the pitch binder phase, resulting in a loss in apparent density and the development of porosity. These characteristics can be improved by pitch impregnation prior to graphitization. To be useful for impregnation, the pitches must be extremely fluid at the temperature of impregnation and free of suspended particles. Economical considerations prefer that the impregnation pitch have properties which allow indefinite storage of the pitch at the impregnation temperature. 
Properties of an acenaphthylene polymer (ACN-340) and cinnamylideneindene polymer (CAl-340) were determined with respect to the heating time at $250^{\circ} \mathrm{C}$ in efforts to determine if degradation of the polymers occurred during the time of study. The polymers, prepared by autoclaving $\mathrm{ACN}$ and CAl for two hours at $340^{\circ} \mathrm{C}$ and 300 -psi pressure (initial room-temperature nitrogen pressure), were heated under a slight flow or argon for 28 days with sampling occurring every seven days. Data obtained are listed in Table 1 and illustrated in Figures 1 through 3.

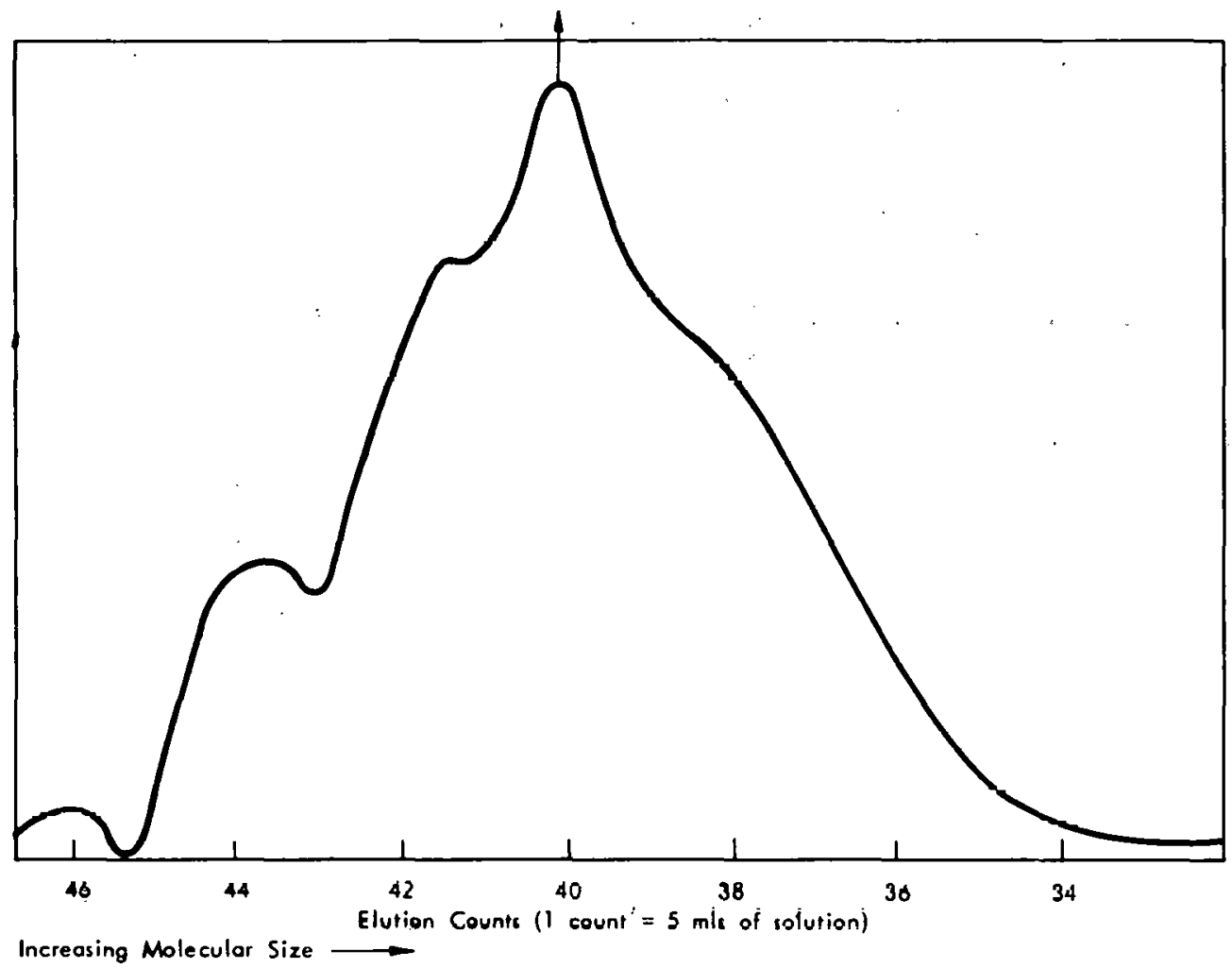

Figure 1. GEL PERMEATIOON CHROMATOGRAPHIC SCAN SHOWING MULẼCULAK UISTRIBU. TION TYPICAL OF THAT OBTAINED FROM CAI-300 THAT WAS HEAT TREATED AT $250^{\circ} \mathrm{C}$.

GPC scans of the CAI-340 polymers rejvealed litrle change in the molecular disiributiun as the heat-treatment time increased. A GPC scan, typical of that obtalned from the CAI-340, is given in Figure 1.

Significant changes in the molecular distribution of the ACN-340 polymer were noted with heat-treatment time, as indicated by the GPC scans presented in Figure 2. Comparison of the scans shows a shift to a lower-molecular-weight species with a significant increase in dimer and trimer content, indicating degradation on heating at $250^{\circ} \mathrm{C}$.

As indicated in Figure 3, softening points of the CAI-340 sample increased slowly as the heat-treatment time increased, probably due to the loss of volatiles and lowermolecular-weight constituents. Softening points of the ACN-340 sample decreased to a minimum with heat-treatment time at $250^{\circ} \mathrm{C}$, indicating that some degradation of the original polymer occurs upon heating. This trend corresponds nicely to the change in 
Table 1

PROPERTIES OF ACENAPHTHLYENE AND CINNAMYLIDENEINDENE IPOLYMERS AS FUNCTIONS OF THE HEATING TIME AT $250^{\circ} \mathrm{C}$

\begin{tabular}{|c|c|c|c|c|c|c|c|c|}
\hline \multirow[b]{2}{*}{ Sámple } & \multirow{2}{*}{$\begin{array}{l}\text { Heating Time } \\
\text { at } 250^{\circ} \mathrm{C} \\
\text { (days) }\end{array}$} & \multirow{2}{*}{$\begin{array}{l}\text { Softening } \\
\text { Point }(1) \\
(0 \mathrm{C})\end{array}$} & \multirow{2}{*}{$\begin{array}{c}\text { Benzene } \\
\text { Insolubles (2) } \\
(\%)\end{array}$} & \multirow{2}{*}{$\begin{array}{c}\text { Carbon } \\
\text { Residue 3) } \\
(\%)\end{array}$} & \multirow{2}{*}{$\begin{array}{c}\text { Coke } \\
\text { Yield (4) } \\
(\%)\end{array}$} & \multicolumn{3}{|c|}{ X-Ray Diffraction Data (5) } \\
\hline & & & & & & $\begin{array}{c}d_{002} \\
\text { (A) }\end{array}$ & $\begin{array}{l}L_{c} \\
(A) \\
\end{array}$ & g Factor \\
\hline \multicolumn{9}{|c|}{ Acenaphthylene Polymer } \\
\hline A & 0 & 210.5 & 0.25 & 38.9 & 42 & 3.364 & 650 & 0.884 \\
\hline B & 7 & 150.8 & 1.38 & 42.2 & 46 & & & \\
\hline $\mathrm{C}$ & 14 & 130.0 & - & 46.4 & 49 & & & \\
\hline D & 21 & 169.8 & - & 57.5 & 61 & & & \\
\hline$E$ & 28 & 224.5 & 47.2 & 77.5 & 77 & 3.362 & 700 & 0.907 \\
\hline \multicolumn{9}{|c|}{ Cinnamylideñeinderie Polymer } \\
\hline A & 0 & 67.2 & 0.04 & 33.7 & 46 & 3.374 & 300 & 0.767 \\
\hline B & 7 & 100.2 & 0.34 & 39.1 & $5 C$ & 3.373 & 450 & 0.779 \\
\hline $\mathrm{C}$ & 14 & 109.0 & 0.33 & 40.1 & 52 & 3.371 & 400 & 0.802 \\
\hline D & 21 & 121.8 & 0.08 & 42.3 & 53 & 3.373 & 350 & 0.779 \\
\hline $\mathbf{E}$ & 28 & 126.2 & ${ }^{\circ} 0.15$ & 43.3 & 53 & 3.371 & 300 & 0.802 \\
\hline
\end{tabular}

(1) Ring and ball method, ASTM D-36-66.

(2) ASTM D-2317.

(3) Conradson, ASTM D-189-65.

(4) Carbonized to $1,000^{\circ} \mathrm{C}$ in an inert atmosphere

(5) Obtained after firing for one hour at $2,800^{\circ} \mathrm{C}$. 


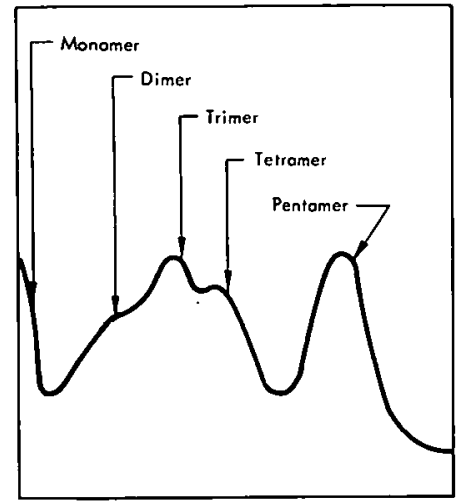

(o) Zoro Dnys.

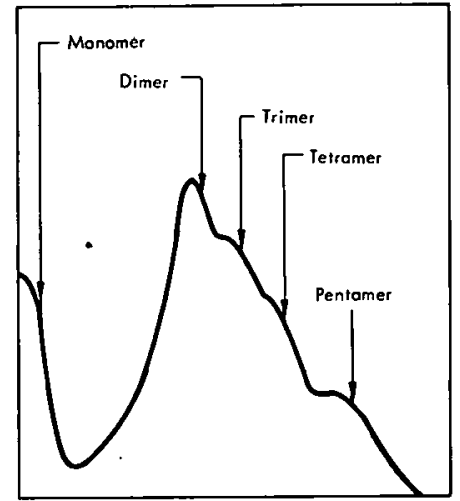

(b) Seven Days.

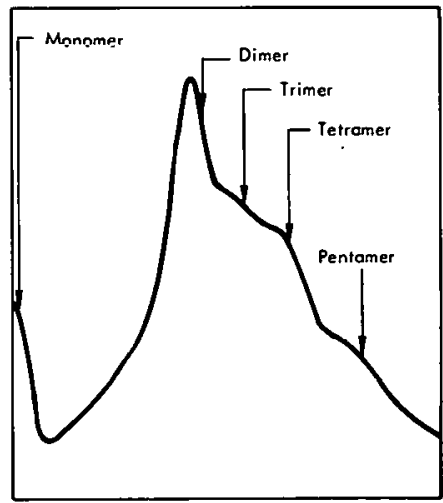

(c) Fourteen Oays

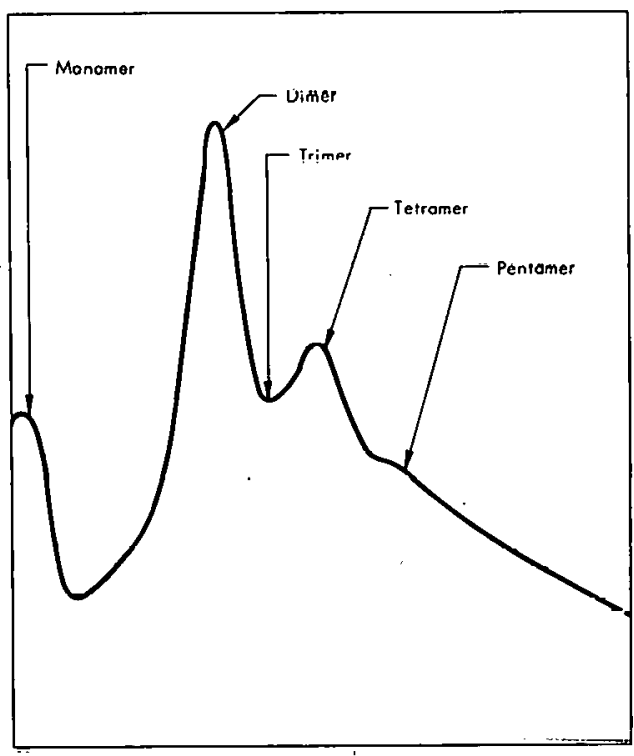

(d) Twenty-One Days.

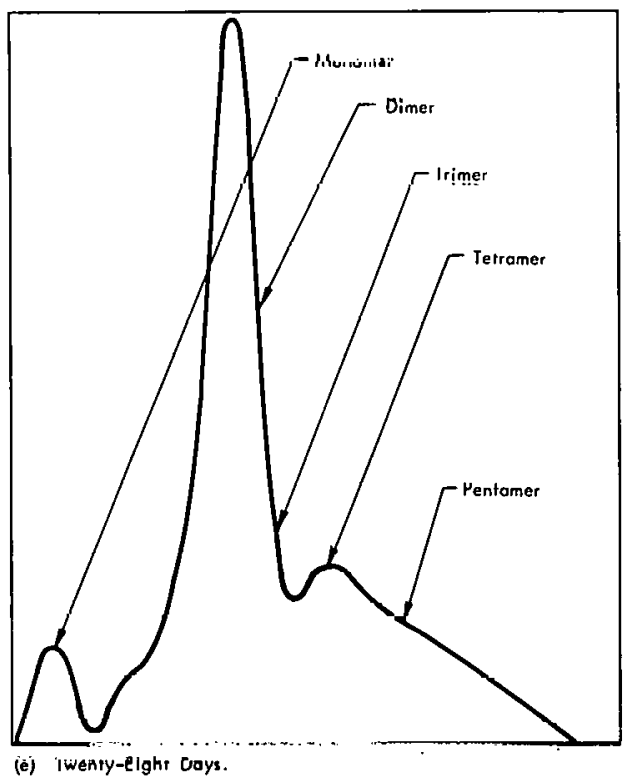

(e) Iwenry-elghr coys.

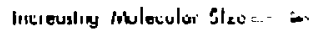

Figure 2. GEL PERMEATION CHROMATOGRAPHIC SCANS SHOWING THE MOLECULAR DISTRIBUTIONS OF ACN-340 DURING HEAT TREATMENT AT $250^{\circ} \mathrm{C}$. (Scans are in the Order of Increasing Molecular Size)

molecular distribution noted in the GPC scans in Figure 2. For heating times longer than 14 days, loss of volatiles and lower-molecular-weight species resulted in an increase in the softening point.

Conradson carbon residues and coke-yield values for the CAI-340 samples appear to reach maximum values of approximately 44 and 53 percent, respectively, as the heat-treatment time at $200^{\circ} \mathrm{C}$ increased. Since little change in the molecular distribution was noted as the heating time increased, little variance in carbon residues and coke yields was expected. Thus, after an initial weight loss due to volatiles and lower-molecular-weight species, carbon residues and coke yields were reasonably constant for the CAI-340 samples as the heating time increased. 

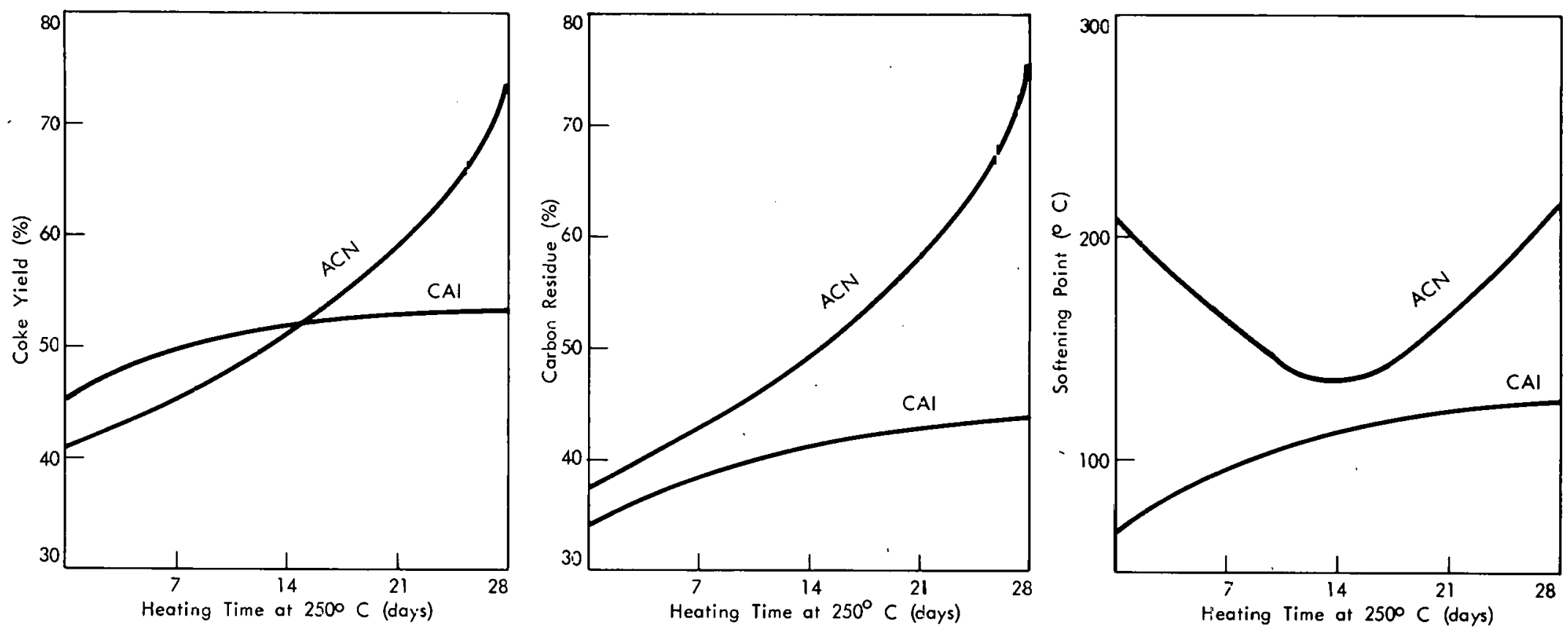

Figure 3. PROPERTIES OF ACN-340 AND CAI-340 AS FUNCTIONS OF THE HEAT-TREATMENT TIME AT $250^{\circ} \mathrm{C}$.

$\vec{\omega}$ 
Coke yields and carbon-residue values of the ACN-340 samples increased rapidly as the heating time at $250^{\circ} \mathrm{C}$ increased. Thus, the dimer and trimer, formed in increasing amounts during the study, must be quite stable compared to the other species present. Upon carbonization, lower-molecular-weight species and volatiles were still lost, but coke yields and carbon residues increased due to the increased amount of dimer and trimer present.

As noted in Table 1, interlayer-spacing $\left(\mathrm{d}_{002}\right)$ and crystallite-size $\left(\mathrm{L}_{c}\right)$ values showed no significant change as the heat treatment time increased. Microstructures typical of the carbons derived from the ACN-340 and CAI-340 samples are given in Figure 4.

In summary, there were significant changes in the physical properties of the ACN-340 upon extended time at $250^{\circ} \mathrm{C}$. Extended heat treatment at $250^{\circ} \mathrm{C}$ results in the increasing formation of dimer and trimer polymer constituents which, in turn, causes variations in polymer properties and the carbon properties of coke vield and carbun residue. However, changes in the CAI-340 were not drastic relative to the original values and probably reflect the loss of volatiles upon extended heat treatment. Carbon crystallinity and the degree of graphiticity were not visibly altered in either the ACN-340 or CAl-340 system as the heat treatment time increased. Thus, CAI-340 could be applicable for uses involving impregnations, while $A C N-340$ may require alteration of process requirements if used for extended periods.

\section{Properties of Carbons Derived from Acenaphthylene and Cinnamylideneindene as Functions of Temperature}

Properties of carbons derived from cinnamylideneindene (CAI) and acenaphthylene (ACN) were measured as a function of temperature over the range from 1,000 to $2,800^{\circ} \mathrm{C}$. The $1,000^{\circ} \mathrm{C}$ carbons were obtained by heating the raw materials on a programmed cycle to $1,000^{\circ} \mathrm{C}$, with a two-hour hold time at the maximum temperature. Successive heat treatments involved heating aliquots of the $1,000^{\circ} \mathrm{C}$ carbons to the respective temperature by use of a carbon induction furnace. All of the samples, except for the $2,800^{\circ} \mathrm{C}$ samples, were heated at the maximum temperature for thirty minutes. The $2,800^{\circ} \mathrm{C}$ samples were heated for one hour at temperature. The resulting carbon data are presented in Table 2.

As noted in Figure 5, helium densities of $\mathrm{ACN}$-derived carbons increased to an apparent maximum as the temperature increased from 1,000 to $1,500^{\circ} \mathrm{C}$, then decreased to a fairly constant value over the temperature range from 1,700 to $2,500^{\circ} \mathrm{C}$. This density decrease was probably due to shrinkage and closing of pore entrances. Helium densities of CAl-derived carbons were essentially constant as the temperature increased to $1,800^{\circ} \mathrm{C}$. In the temperature range from 1,800 to $2,200^{\circ} \mathrm{C}$, the helium density of the CAl-derived carbon increased, indicating a volume contraction. Above $2,200^{\circ} \mathrm{C}$, helium density values were essentially constant.

Interlayer-spacing values of the $\mathrm{ACN}$-derived carbons revealed a slow growth of the graphitic structure as the temperature increased to $2,000^{\circ} \mathrm{C}$. In the temperature range from 2,000 to $2,500^{\circ} \mathrm{C}$, three-dimensional ordering occurred as the $\mathrm{d}_{002}$ values decreased frum 3.423 to $3.372 \mathrm{~A}$. Ordering occurred at a much slower rate above $2,500^{\circ} \mathrm{C}$. Corresponding $\mathrm{L}_{c}$ values 

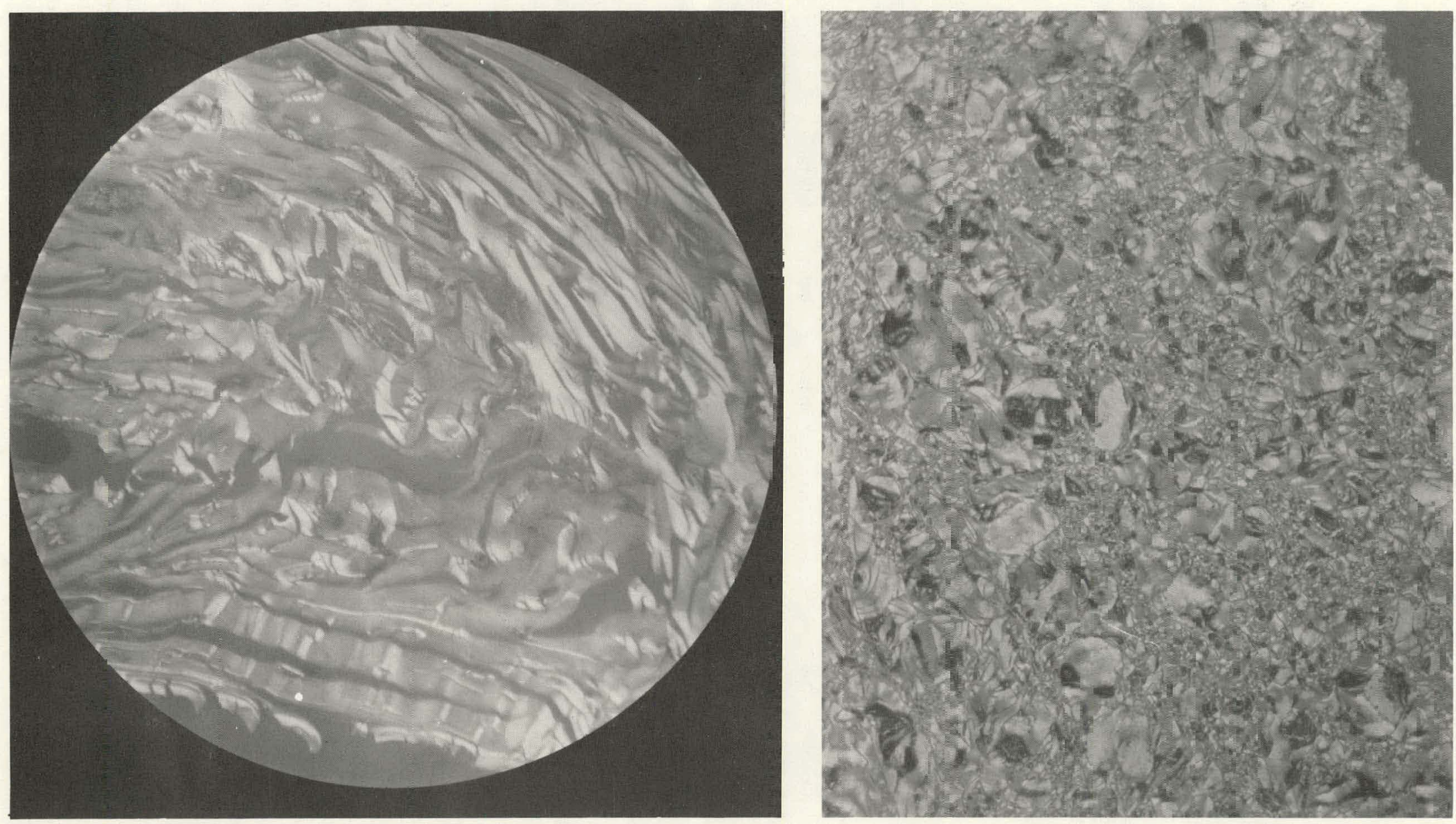

1487-1 
Table 2

PROPERTIES OF CARBONS DERIVED FROM ACENAPHTHYLENE AND CINNAMYLIDENEINDENE AS FUNCTIONS OF THE TEMPERATURE

\begin{tabular}{|c|c|c|c|c|}
\hline \multirow[b]{2}{*}{$\begin{array}{c}\text { Temperature }(1) \\
(0 \mathrm{C})\end{array}$} & \multirow{2}{*}{$\begin{array}{l}\text { Helium } \\
\text { Density (2) } \\
\left(\mathrm{gms} / \mathrm{cm}^{3}\right)\end{array}$} & \multicolumn{3}{|c|}{ X-Ray Diffraction Data } \\
\hline & & $\begin{array}{l}\mathrm{d}_{002} \\
\text { (A) }\end{array}$ & $\begin{array}{l}L_{c} \\
\text { (A) }\end{array}$ & g Factor \\
\hline \multicolumn{5}{|c|}{ Cinnamylideneindene } \\
\hline 1,000 & 1.88 & (3) & - & - \\
\hline 1,250 & 1.97 & (3) & - & - \\
\hline 1,500 & 2.08 & (3) & - & - \\
\hline 1,760 & 2.04 & 3.4160 & 58 & 0.279 \\
\hline 2,020 & 2.14 & 3.4292 & 95 & 0.062 \\
\hline 2,480 & 2.22 & 3.3812 & 114 & 0.684 \\
\hline $2,8 \cap 0$ & 2.22 & 3.3640 & 230 & 0.881 \\
\hline \multicolumn{5}{|c|}{ Acenaphthlyene } \\
\hline 1,000 & 1.97 & (3) & - & - \\
\hline 1,250 & 2.14 & (3) & - & - \\
\hline 1,500 & 2.24 & 3.4292 & 41 & 0.062 \\
\hline 1,760 & 2.14 & 3.4250 & 87 & 0.087 \\
\hline 2,020 & 2.16 & 3.4190 & 141 & 0.244 \\
\hline 2,480 & 2.16 & 3.3730 & 236 & 0.779 \\
\hline 2,800 & - & 3.3622 & 385 & 0.905 \\
\hline
\end{tabular}

(1) Samples heated for 30 minutes at the indicated temperature in an Astro Model $1000 \mathrm{~A}$ furnace. Samples at $2,800^{\circ} \mathrm{C}$ hcatcd for one hour in a carbon-induction furnace.

(2) Density obtained by helium displacement.

(3) No measurable peaks on the X-ray diffractions scans.

increased slowly in the temperature range from 2,000 to $2,500^{\circ} \mathrm{C}$, and more rapidly at temperatures above $2,500^{\circ} \mathrm{C}$. The $\mathrm{d}_{002}$ and $\mathrm{L}_{\mathrm{C}}$ values for the $2,800^{\circ} \mathrm{C}$ carbons are those of a highly graphitic carbon. Figure 4 contains a photomicrograph which shows the microstructure that is typical of carbons obtained from ACN.

Interlayer-spacing values for carbon derived from $\mathrm{CAl}$ indicated an apparent maximum in disorientation as the temperature increased to $2,000^{\circ} \mathrm{C}$. though helium-density values indicated an increase in the degree of crystallinity and orientation for this region. Variance in the d 002 values probably does not go through a maximum and, thus, should resemble the data obtained for the ACN carbons. Since the carbons from both CAI and ACN have such a low order of graphiticity in this region, X-ray diffraction scans tend to be quite diffuse. I hus, the $d_{002}$ and $L_{c}$ values obtained in this region contain a higher degree of error than the helium-density values.

At temperatures above $2,000^{\circ} \mathrm{C}$, crystallite growth processes predominate and the variance in the $\mathrm{d}_{002}$ values again resemble that noted for the $A C N$-derived carbons, though $L_{C}$ values increased at a much slower rate than the $L_{C}$ values for ACN-derived carbons. The interlayer-spacing and crystallite-size values of the $2,800^{\circ} \mathrm{C}$ carbon are those of a highly graphitic structure, though less graphitic than that obtained from ACN. A microstructure typical of carbon derived from CAl can also be seen in Figure 4. 

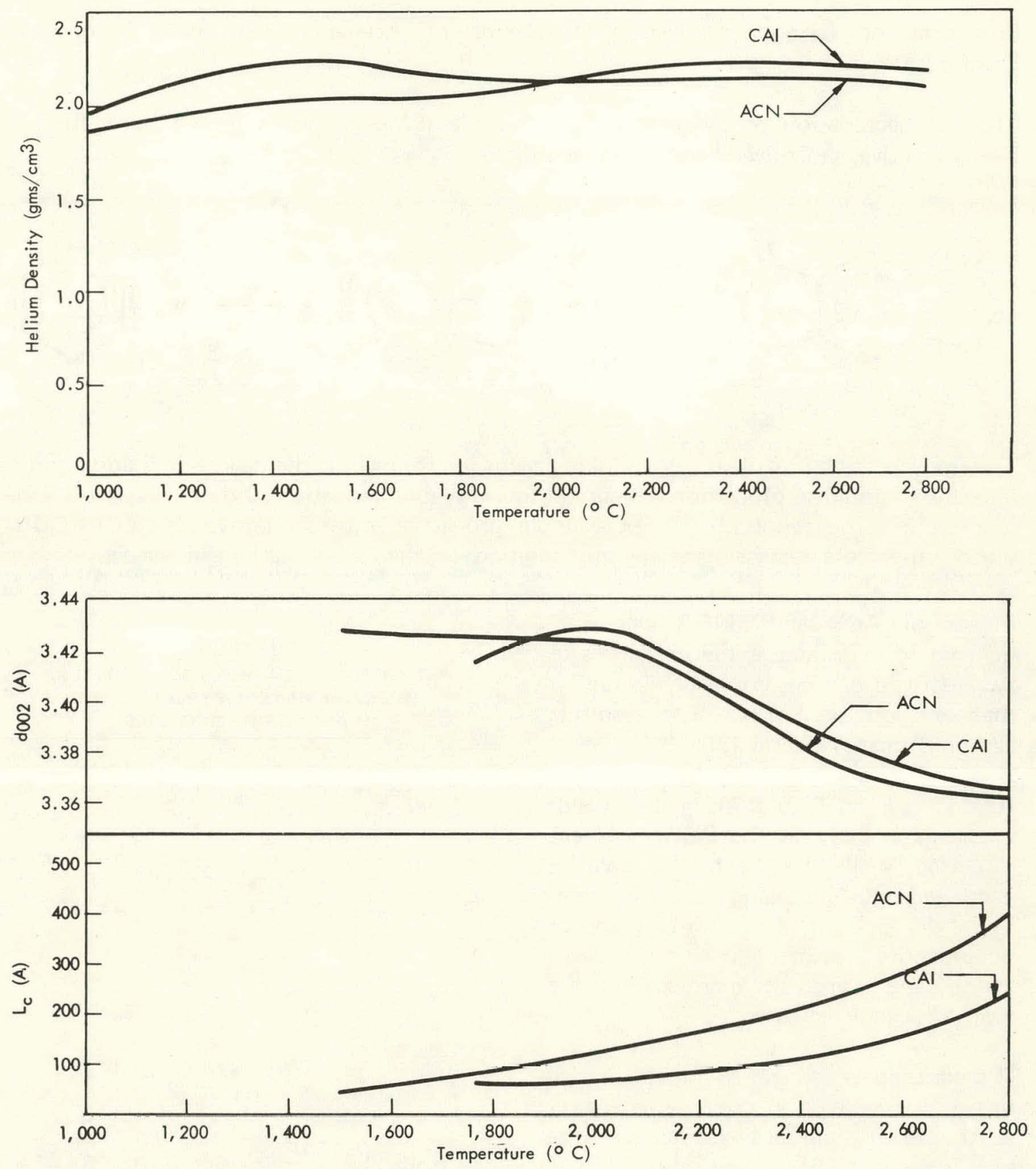

Figure 5. PROPERTIES OF CARBONS DERIVED FROM ACENAPHTHYLENE AND CINNAMYLIDENEINDENE AS FUNCTIONS OF TEMPERATURE.

In summary, it can be said that the densification at 1,400 to $1,600^{\circ} \mathrm{C}$ and the ordering of the crystal structure above $2,000^{\circ} \mathrm{C}$ of carbon derived from $\mathrm{ACN}$ are quite common to graphitizing carbons. Though $\mathrm{CAl}$-derived carbons densify in the temperature range from 1,800 to $2,100^{\circ} \mathrm{C}$, ordering of the crystal structure also occurs in the temperature range corresponding to graphitizing carbons. Carbon data indicate that CAI-derived carbon is of a lower order of graphiticity than is ACN-derived carbon. 
Properties of Carbons Derived from Blends of Acenaphthylene with Pyromellitic Dianhydride

Thermal degradation of pyromellitic dianhydride (PMDA) results in the production of highly reactive, short-lived benzyne intermediates:
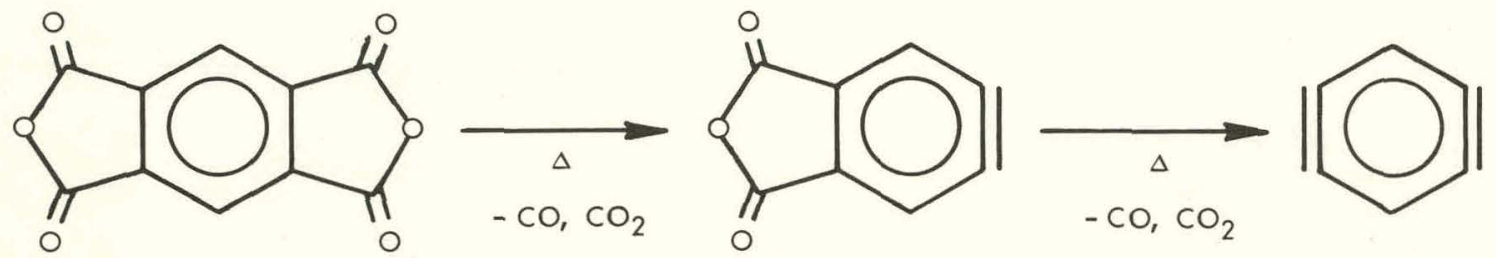

The usefulness of PMDA as a crosslinking aqent for controlling the deqree of fluidity and/or molecular mobility of carbon precursors during polymerization and pyrolysis has been reported in earlier reports. $(2,6)$ For example, properties of carbon derived from CAI/PMDA blends reflected a decreasing degree of graphiticity as the PMDA content increased. (2)

Blends of ACN and PMDA were carbonized to determine if the properties of ACN-derived carbons could be altered by the addition of PMDA. The resulting carbon data are listed in Table 3 .

As noted in Figure 6, coke yields increased steadily as the PMDA content increased, while the graphitic properties decreased with increasing PMDA content. Thus, the amount of crosslinking and/or nonplanarity occurring during polymerization and pyrolysis increased as the PMDA content increased.

Microstructures, shown in Figure 7, also reveal the decrease in graphitic character

Table 3

PROPERTIES OF CARBONS DERIVED FROM ACENAPHTHLYENE/PYROMELLITIC DIANHYDRIDE MIXTURES

\begin{tabular}{|c|c|c|c|c|c|}
\hline \multirow[b]{2}{*}{ Sample } & \multirow{2}{*}{$\begin{array}{c}\text { PMDA } \\
\text { Content } \\
(\%)\end{array}$} & \multirow{2}{*}{$\begin{array}{c}\text { Coke } \\
\text { Yield(1) } \\
(\%)\end{array}$} & \multicolumn{3}{|c|}{ X-Ray Diffraction Data (2) } \\
\hline & & & $\begin{array}{c}d_{002} \\
\text { (A) }\end{array}$ & $\begin{array}{l}\mathrm{L}_{C} \\
(\mathrm{~A})\end{array}$ & g Factor \\
\hline A & 0 & 30 & 3.3622 & 385 & 0.905 \\
\hline B & 10 & 35 & 3.3616 & 379 & 0.912 \\
\hline C & 20 & 37 & 3.3644 & 336 & 0.879 \\
\hline $\mathrm{D}$ & 30 & 38 & 3.3684 & 232 & 0.833 \\
\hline E & 40 & 50 & 3,4268 & 40 & 0.078 \\
\hline $\mathrm{F}$ & 50 & 46 & (3) & - & - \\
\hline
\end{tabular}

(1) Obtained after heating to $1,000^{\circ} \mathrm{C}$ in an inert atmosphere.

(2) Obtained after firing for one hour at $2,800^{\circ} \mathrm{C}$.

(3) No measurable peak at the 002 plane. as the PMDA content increased. Little microstructural change was noted among carbons from blends containing up to 20 percent PMDA. However, as the PMDA content increased from 20 to 30 and 40 percent, significant decreases in crystallinity were observed. Carbons from blends containing PMDA concentrations of 40 percent or higher were noncrystalline. Thus, the addition of PMDA to ACN alters the properties of the carbon derived from $A C N$ in a reproducible and controllable manner.

Properties of Carbons Derived from Blends of Acenaphthylene and Cinnamylideneindene with Furfurylideneindene

Furfurylideneindene (FAI), a thermosetting indene derivative which yields a noncrystalline carbon on graphitization, was blended with $A C N$ and $C A I$ in efforts to utilize the 


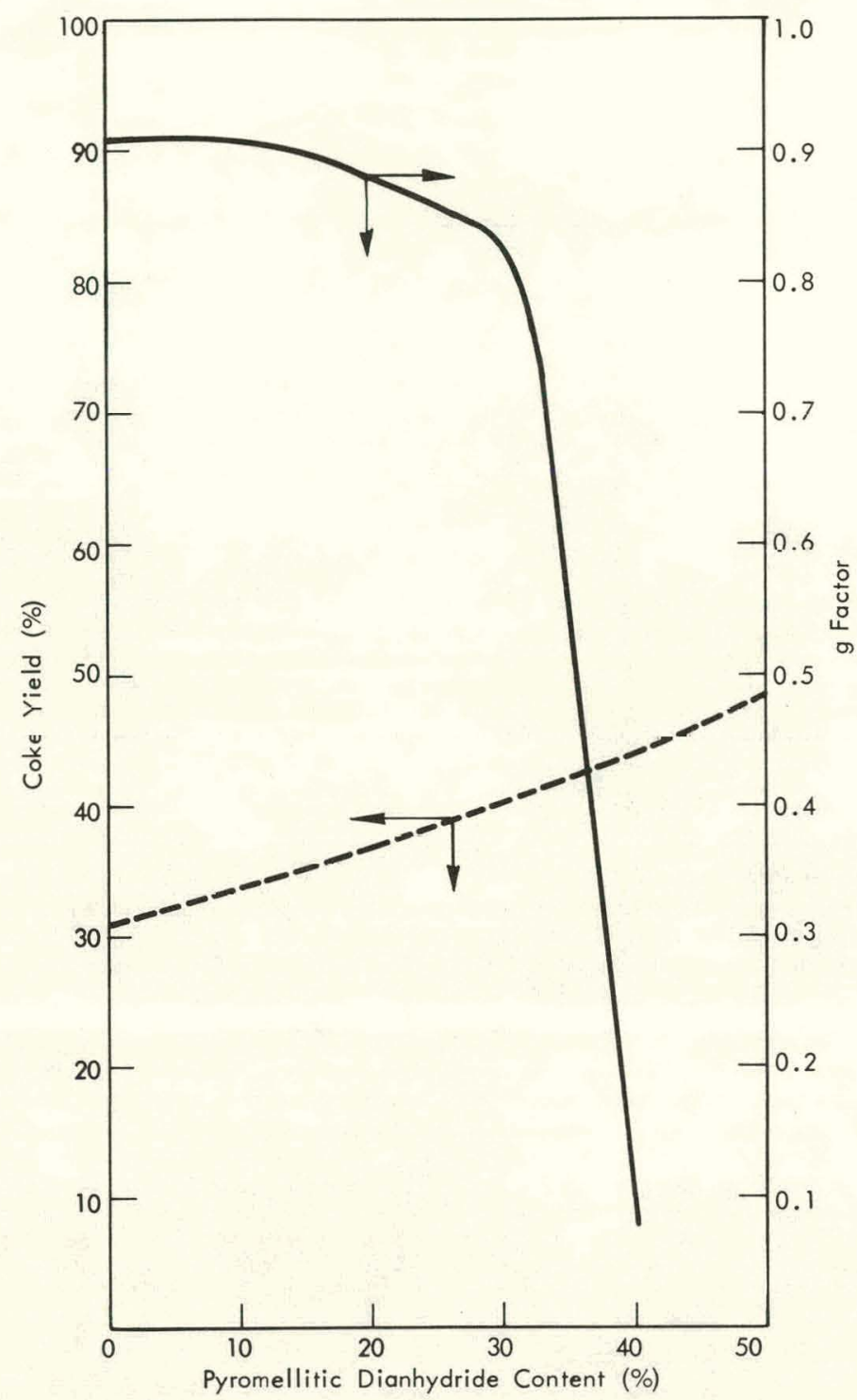

Figure 6. PROPERTIES OF CARBONS DERIVED FROM ACENAPHTHYLENE/PYROMELLITIC DIANHYDRIDE MIXTURES AS FUNCTIONS OF THE PYROMELLITIC DIANHYDRIDE CONTENT.

thermosetting properties of the $\mathrm{FAl}$ as a crosslinking agent. Data for the carbonized blends are presented in Table 4.

Acenaphthylene/Furfurylideneindene Mixtures - As indicated in Figure 8, coke yields gradually increased as the FAI content increased, while no significant change in the degree of graphiticity occurred for compositions corresponding to less than 60 percent FAI. For FAl contents greater than 60 percent, a rapid decrease in the degree of graphiticity was observed. 


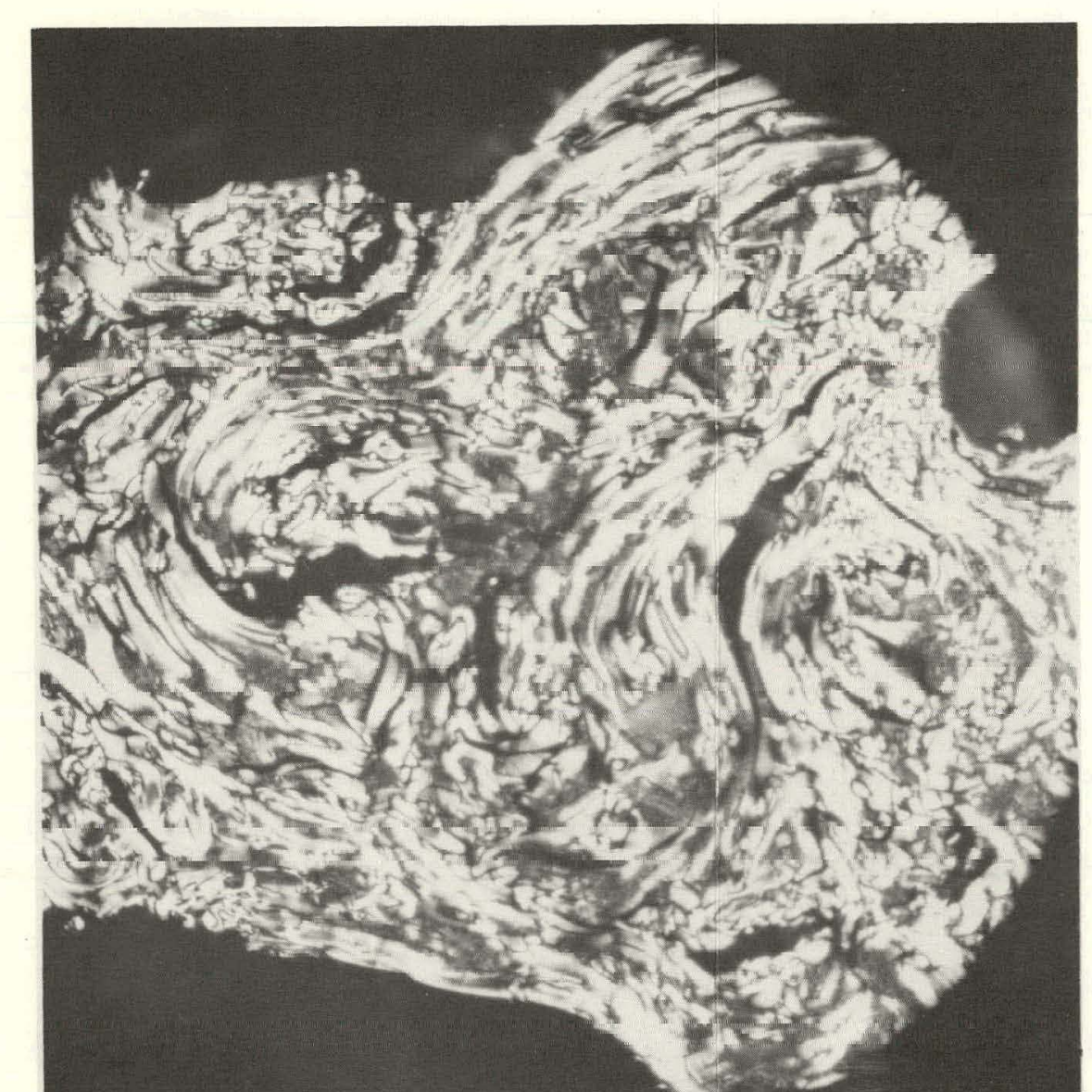

(a) $20 \%$ PMDA.

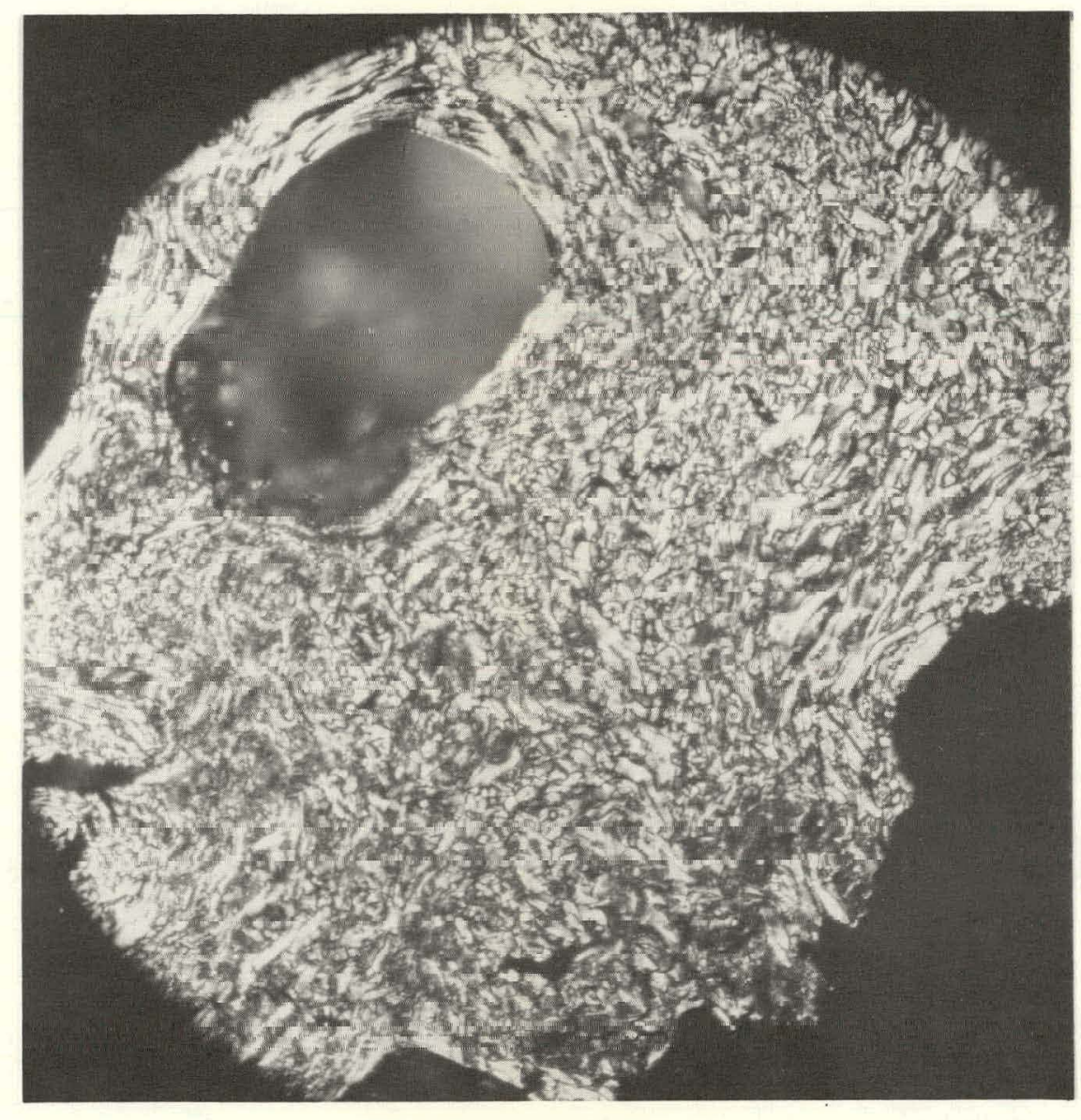

$\begin{array}{ll}\text { MS-71.0839-8 } & \text { (b) } 30 \% \text { PMDA. }\end{array}$

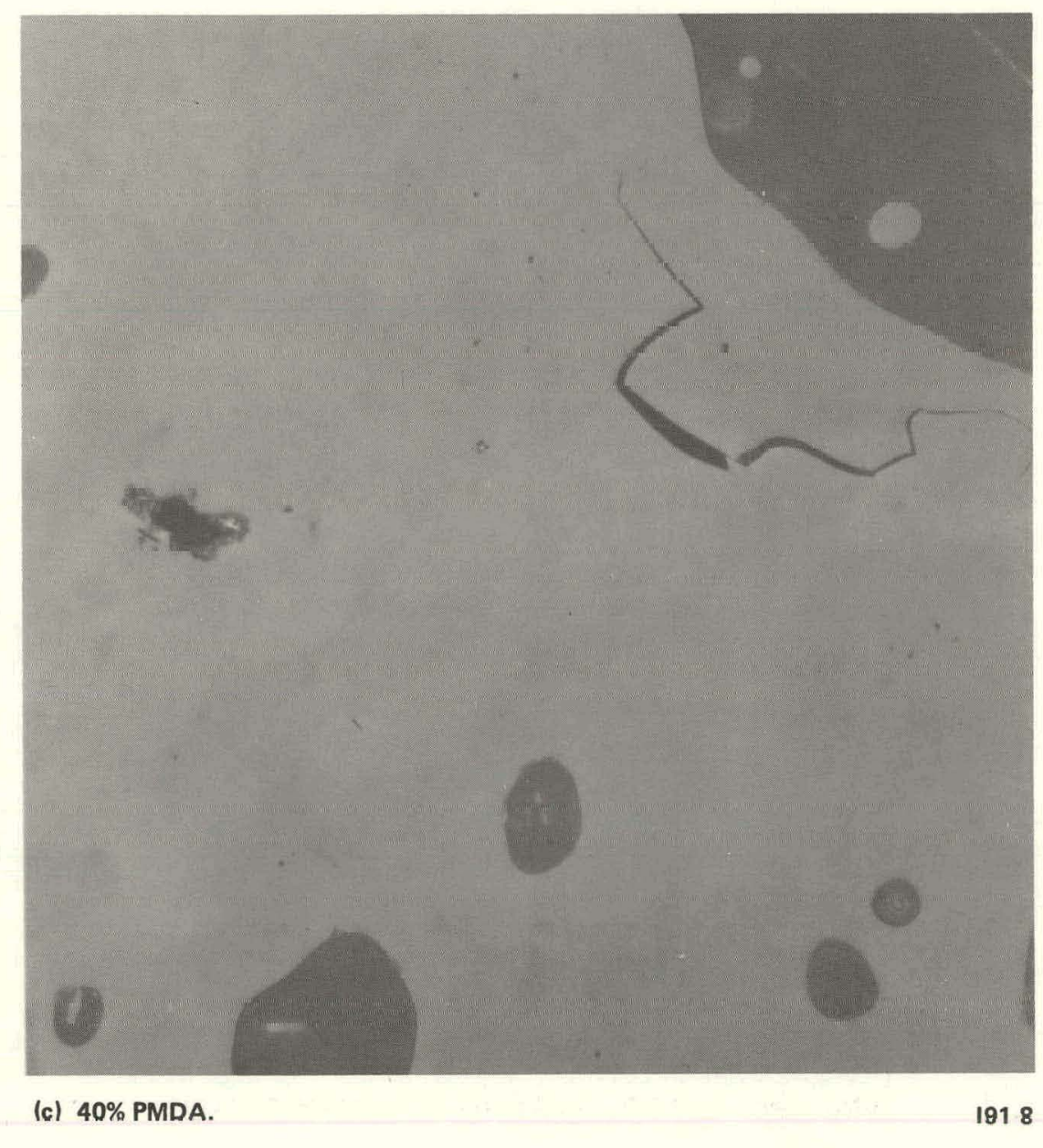

MS-71-ก839.9 (c) 40\% PMDA.

Figure 7. MICROSTRUCTURES OF CARBONS (AFTER 2,800 $\mathrm{C}$ ) DERIVED FROM ACENAPHTHYLENE/PYROMELLITIC DIANHYDRIDE MIXTURES. (Sensitive Tint; 250X) 
Table 4

PRTPERTIES OF CARBONS DERIVED FROM MIXTURES OF FURFURYLIDENEINDENE WITH ACENAPHTHYLENE

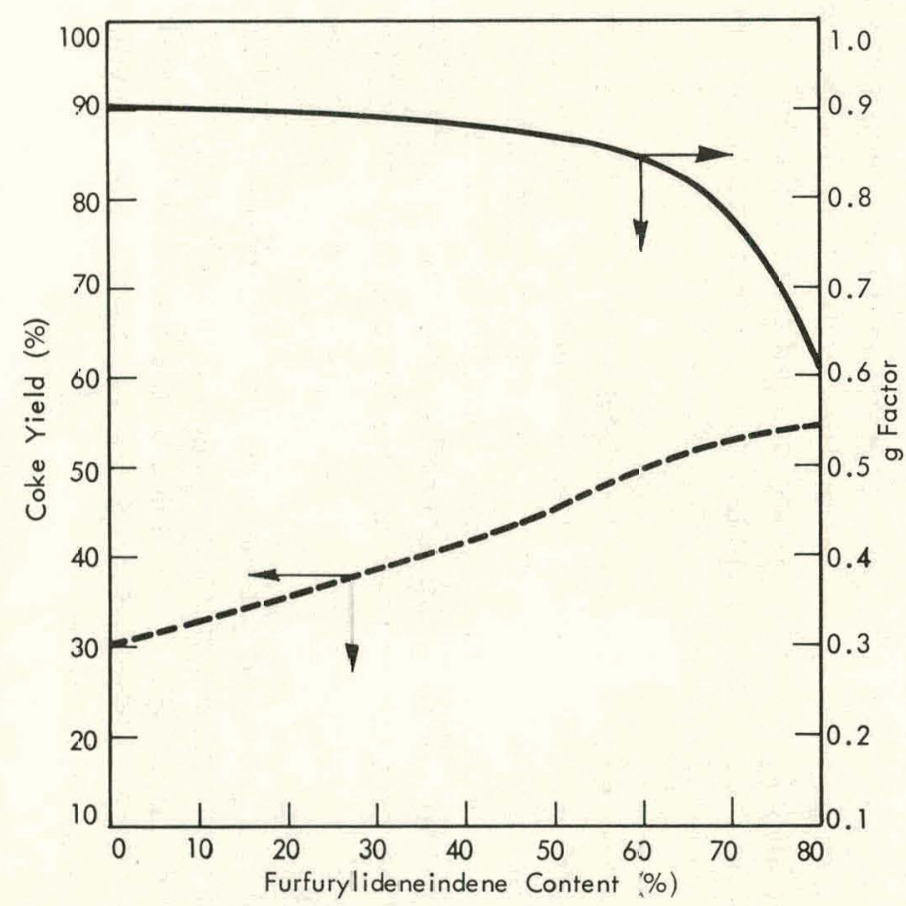

Figure 8. PROPERTIES CF CARBON DERIVED FROM ACENAPH THYLENE/FURFURIYLIDENEINDENE MIXTURES AS FUNCTIONS OF THE FURFURYLIDENEINDENE CONTENT.

$$
\text { AND CINNAMY LIDENEINDENE }
$$

\begin{tabular}{|c|c|c|c|c|c|}
\hline \multirow[b]{2}{*}{ Sampl } & \multirow{2}{*}{$\begin{array}{c}\text { FAl } \\
\text { Content } \\
(\%)\end{array}$} & \multirow{2}{*}{$\begin{array}{c}\text { Coke } \\
\text { Yield } \\
(\%)\end{array}$} & \multicolumn{3}{|c|}{ X-Ray Diffraction Data } \\
\hline & & & $\begin{array}{c}\mathrm{d}_{002} \\
\text { (A) }\end{array}$ & $\begin{array}{l}L_{C} \\
\text { (A) }\end{array}$ & $\mathrm{g}$ Factor \\
\hline & & \multicolumn{2}{|c|}{ Cinnamylideneindene } & & \\
\hline A & 0 & 32 & 3.3628 & 248 & 0.898 \\
\hline B & 10 & 36 & 3.3634 & 129 & 0.891 \\
\hline C & 20 & 39 & 3.3656 & 142 & 0.865 \\
\hline D & 30 & 44 & 3.3724 & 88 & 0.786 \\
\hline $\mathrm{E}$ & 40 & 46 & 3.3720 & 93 & 0.791 \\
\hline $\mathrm{F}$ & 50 & 48 & 3.3782 & 103 & 0.719 \\
\hline$G(1)$ & 50 & 50 & 3.3684 & 135 & 0.833 \\
\hline$H^{(1)}$ & 60 & 45 & 3.3730 & 107 & 0.779 \\
\hline \multirow[t]{2}{*}{ I(1) } & 70 & 50 & 3.3828 & 77 & 0.665 \\
\hline & & \multicolumn{2}{|c|}{ Acenaphthylene } & & \\
\hline A & 0 & 30 & 3.3622 & 385 & 0.905 \\
\hline B & 10 & 33 & 3.3622 & 423 & 0.905 \\
\hline C & 20 & 35 & 3.3634 & 380 & 0.891 \\
\hline$D$ & 30 & 39 & 3.3634 & 385 & 0.891 \\
\hline$E$ & 40 & 41 & 3.3656 & 357 & 0.865 \\
\hline $\mathrm{F}$ & 50 & 42 & 3.3656 & 301 & 0.865 \\
\hline G & 60 & 51 & 3.3672 & 229 & 0.847 \\
\hline $\mathrm{H}$ & 70 & 53 & 3.3724 & 120 & 0.786 \\
\hline 1 & 80 & 54 & 3.3880 & 108 & 0.605 \\
\hline
\end{tabular}

(1) Samples consisted of 200-gram blends. 
Microstructures of carbons after $2,800^{\circ} \mathrm{C}$ (Figure 9) were highly crystalline for compositions containing up to 60 percent FAI. However, as the FAl content increased to 70 and 80 percent, the crystallinity decreased to a more homogeneous, smaller-grain microstructure and a fine-grain, homogeneous microstructure, respectively. Thus, properties of ACN-derived carbon can be altered by the inclusion of FAI. However, since concentrations of FAl greater than 60 percent are necessary to invoke noticeable changes in microstructure, possible applications of this system are limited to those uses which can tolerate the high levels of oxygen present.

Cinnamylideneindene/Furfurylideneindene Mixtures - Coke yields of carbons derived from CAI/FAI mixtures also increased steadily as the FAl content increased, as indicated in Figure 10. The degree of graphiticity decreased more rapidly with increasing FAl content than was noted for the ACN/FAI system. Thus, it appears that CAI was more susceptible to the crosslinking characteristics of the FAl during polymerization.

Microstructures of the $2,800^{\circ} \mathrm{C}$ carbon also revealed a decrease in graphiticity as the $\mathrm{FAl}$ content increased (Figure 11). Microstructures decreased in crystallinity from a highly crystalline carbon typical of CAI to a fine-grain, homogeneous carbon.

Thus, the copolymerization of CAI and FAI resulted in an increased amount of crosslinking and/or nonplanarity in the polymeric system as the FAI content increased. However, less FAI was necessary to effect noticeable microstructural and graphitical changes in the CAI than was required for the $\mathrm{ACN}$ system, indicating a greater degree of miscibility and/or interaction between the $\mathrm{CAl}$ and $\mathrm{FAl}$ during polymerization.

In order to economically obtain the quantities of carbon necessary to fabricate parts, large batches of the precursor blends must be carbonized. To determine if carbon properties were altered by batch sizes, blends of CAI and FAl containing 50,60, and 70 percent $\mathrm{FAl}$ were carbonized in 200-gram quantities. Data are recorded in Table 4 and shown in Figures 10 and 12. These data indicated that by increasing the batch size an increase in the degree of graphiticity was obtained. For example, carbon derived from a 200-gram CAI/FAI mixture containing 60 percent $\mathrm{FAl}$ was similar in microstructure and graphitic properties to carbon from a 30-gram CAI/FAI mixture containing 40 percent FAI.

FAI was also blended with autoclave-polymerized CAI (CAI-340) to determine if the properties of the resulting carbons were altered. Blends of the FAI and CAI-340 were prepared by adding $\mathrm{FAI}$ to molten CAI-340 with stirring. After stirring the mixture for approximately five minutes, the blend was allowed to cool to room temperature. Larbonization consisted of heating 30 grams of the blend to $1,000^{\circ} \mathrm{C}$ inl dil intel atmosphere, followed by heat treating the carbons for one hour at $2,800^{\circ} \mathrm{C}$. Carbon data are presented in Table 5.

Coke yields of the blends increased gradually as the FAl content increased (Figure 13), probably indicative of the increased crosslinking and/or nonplanarity in the polymer system during polymerization and pyrolysis. Coke yields of the $\mathrm{FAl} / \mathrm{CAl}-340$ blends are higher than coke yields of the $\mathrm{FAI} / \mathrm{CAl}$ blends; due, probably, to the loss of volatiles during the autoclaving and blend-preparation steps. 


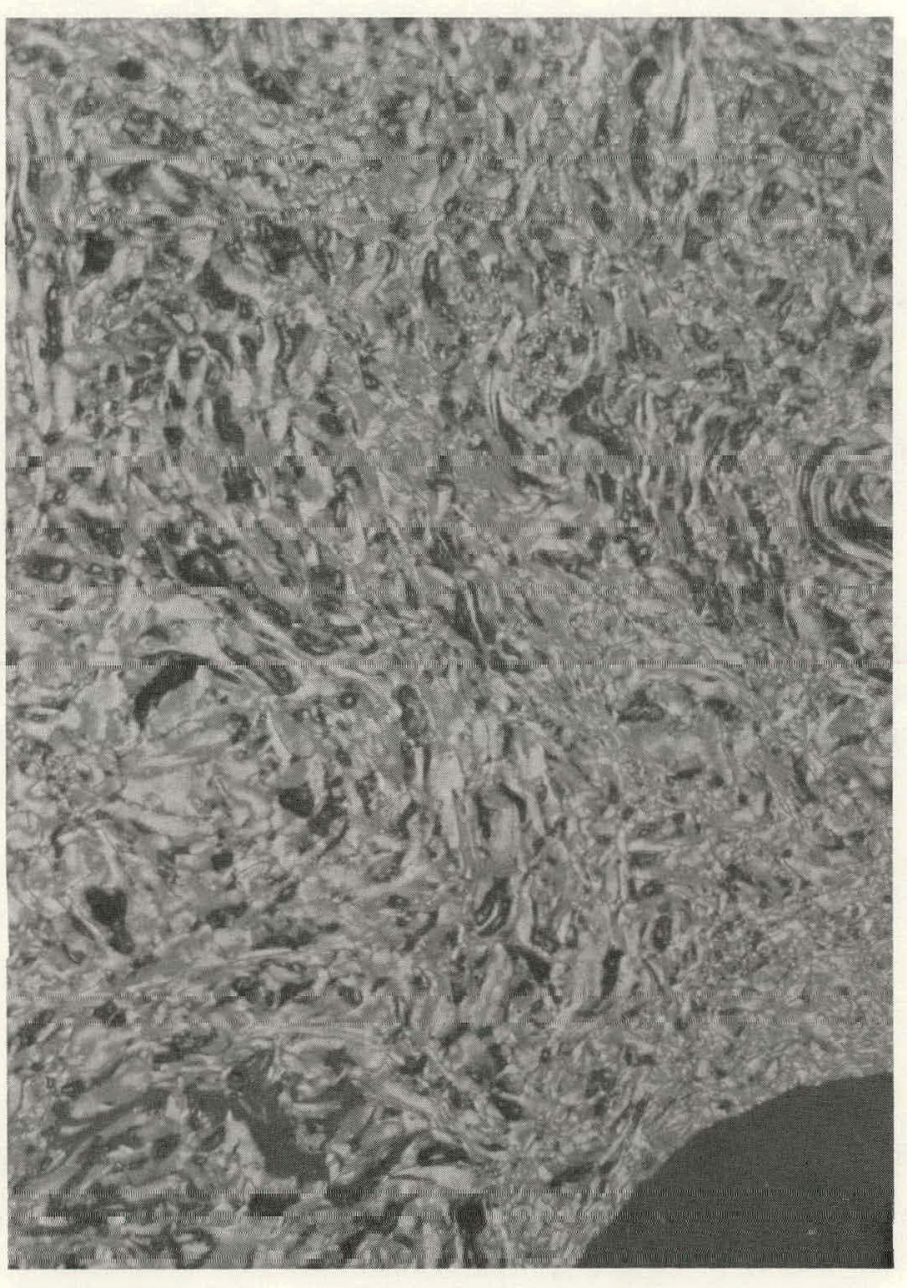

(a) $60 \%$ FAI.

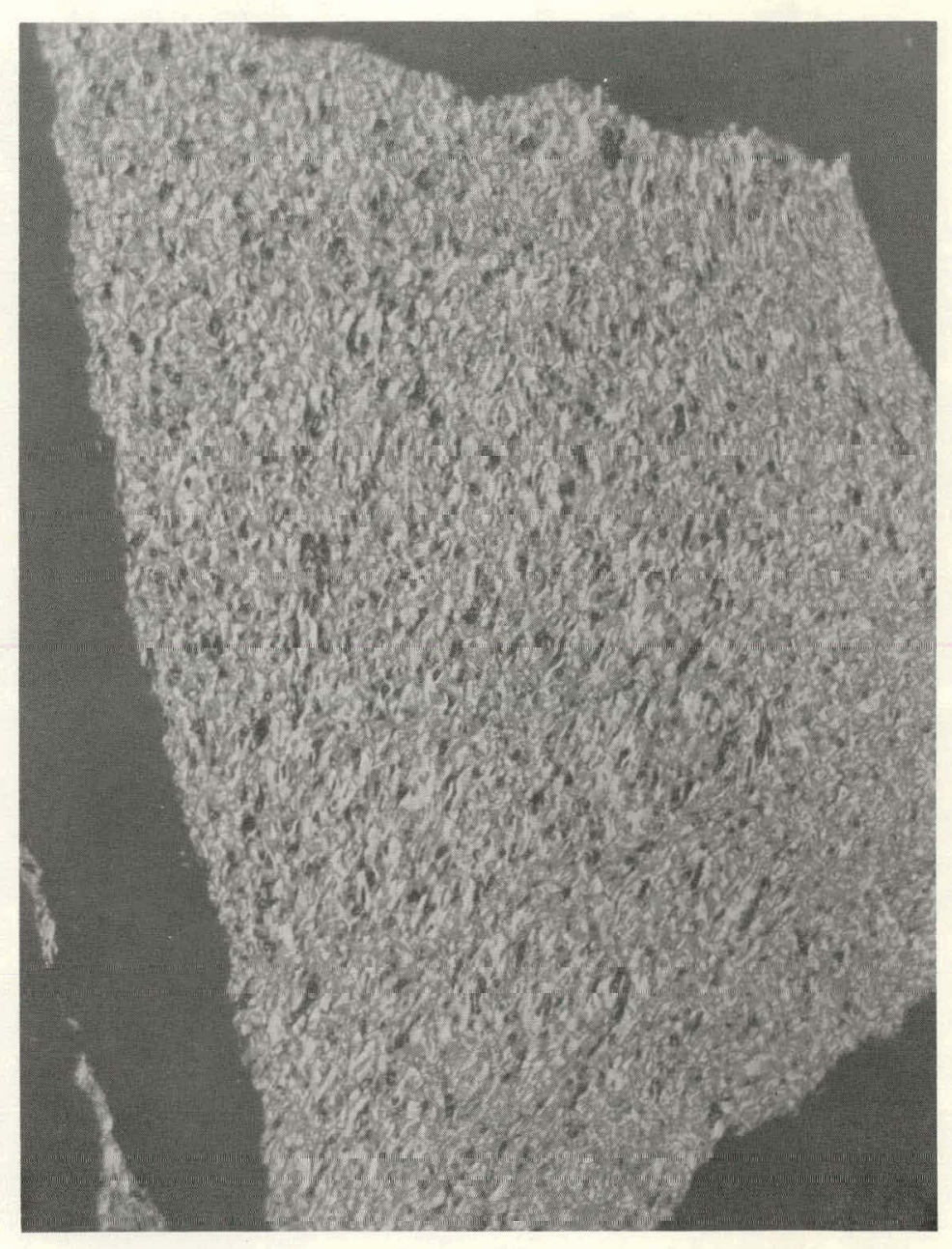

(b) $70 \%$ FAI.

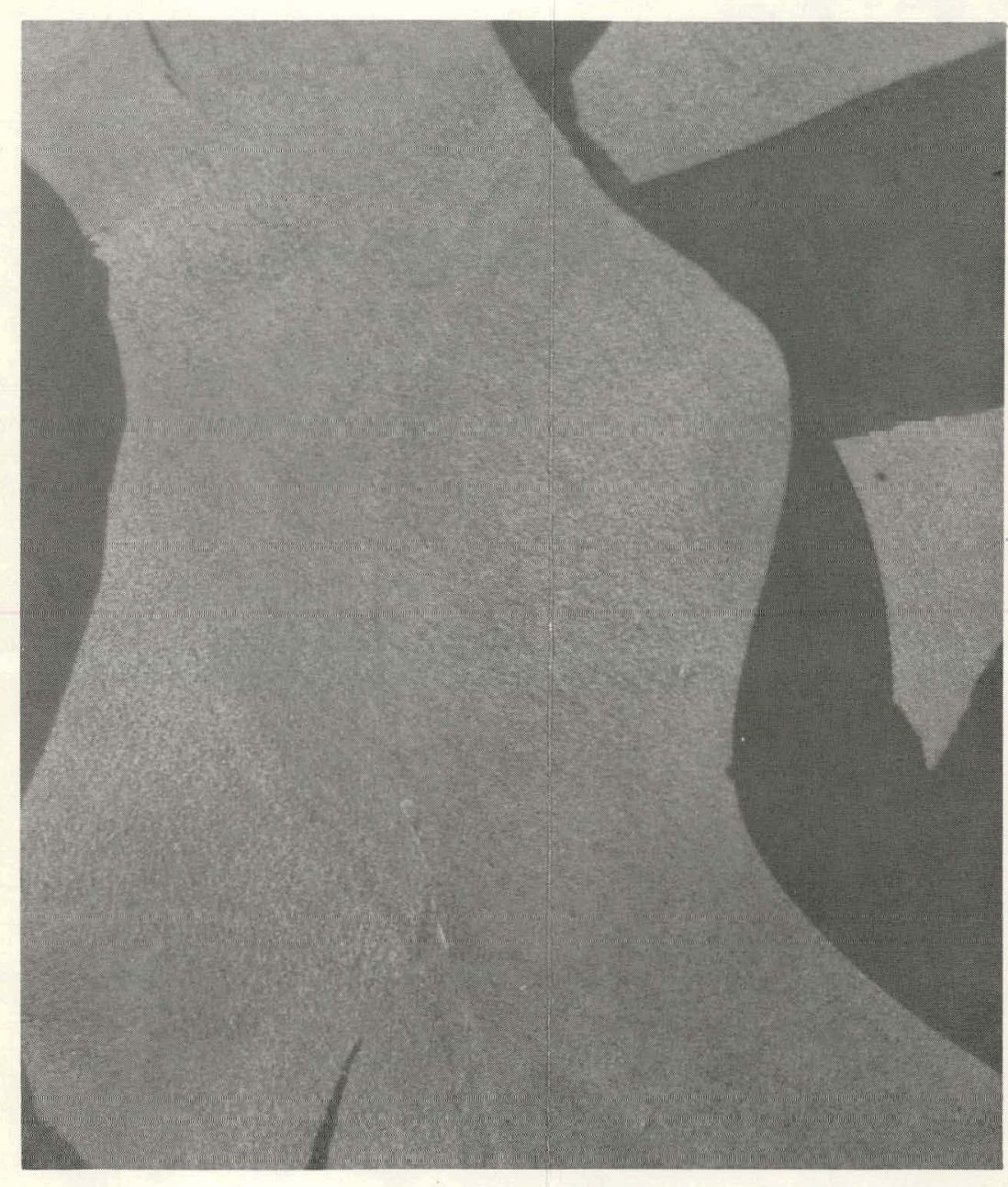

(c) $80 \%$ FAl.

$191-12$

Fiqure 9. MICROSTRUCTURES OF CARBONS (AFTER $2.800^{\circ} \mathrm{C}$ ) DERIVED FROM ACENAPHTHYLENE/FURFURYLIDENEINDENE MIXTURES. (Sensitive Tint; 250X) 


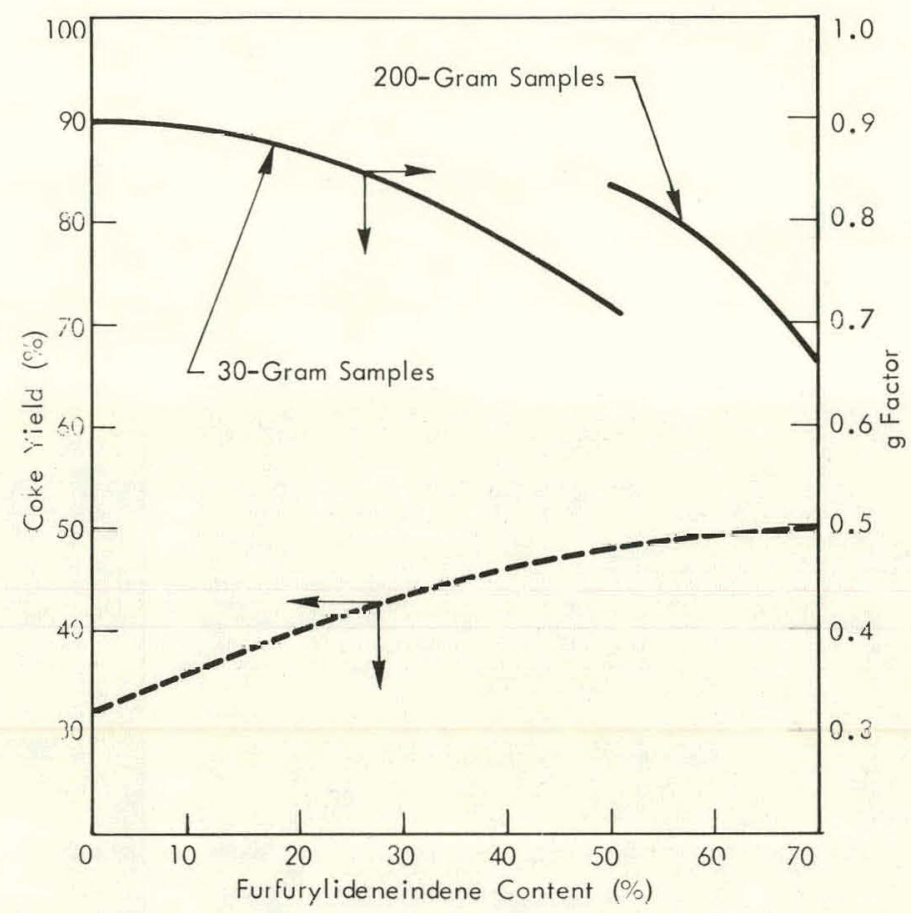

Figure 10. PROPERTIES OF CARBON DERIVED FROM CINNAMYLIDENEINDENE/FURFURYLIDENEINDENE MIXTURES AS FUNCTIONS OF THE FURFURYLIDENEINDENE CONTENT.

Table 5

PROPERTIES OF CARBONS DERIVED FROM BLENDS OF FURFURYLIDENEINDENE AND AUTOCLAVEPOLYMERIZED CINNAMYLIDENEINDENE

\begin{tabular}{|c|c|c|c|c|c|}
\hline \multirow[b]{2}{*}{ Sample } & \multirow{2}{*}{$\begin{array}{c}\text { मAI } \\
\text { Content } \\
(\%)\end{array}$} & \multirow{2}{*}{$\begin{array}{l}\text { Coke } \\
\text { Yield (1) } \\
(\%)\end{array}$} & \multicolumn{3}{|c|}{ X-kay ulffraction Data (2) } \\
\hline & & & $\begin{array}{c}\mathrm{d}_{002} \\
\text { (A) }\end{array}$ & $\begin{array}{l}L_{C} \\
\text { (A) }\end{array}$ & g Factor \\
\hline A & 0 & 47 & 3.3672 & 270 & 0.847 \\
\hline B & 10 & 50 & 3.3720 & 169 & 0.791 \\
\hline C & 20 & 49 & 3.3708 & 149 & 0.805 \\
\hline D & 40 & 53 & 3.3770 & 128 & 0.133 \\
\hline$t$ & bu & 55 & 3.3806 & 110 & 0.691 \\
\hline
\end{tabular}

(1) Obtained after heating to $1,000^{\circ} \mathrm{C}$ in an inert atmosphere.

(2) Obtained after tiring for one hour at $2,800^{\circ} \mathrm{C}$.

The degree of graphiticily of th $2,800^{\circ} \mathrm{C}$ carbons decreased in a gradual manner as the FAI content increased, as indicated by Figure 13 and the microstructures shown in Figure 14. Thus, carbon crystallinity decreased from a highly crystalline, heterogeneous microstructure to a fine-grain, homogeneous microstructure as the FAl content increased from 0 to 50 percent.

Of interest was the fact that FAI has a similar effect on carbons derived from monomeric $\mathrm{CAI}$ and $\mathrm{CAI}-340$. Since one mode of interaction (copolymerization) was eliminated by the 


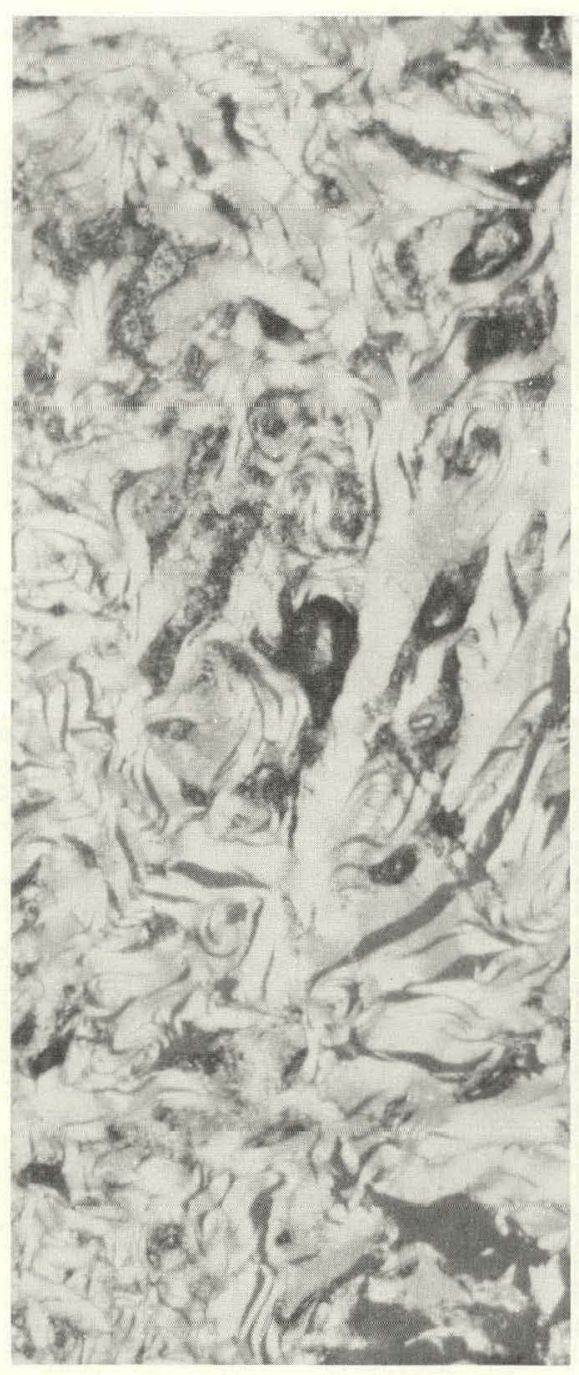

(a) $0 \% \mathrm{FAl}$.

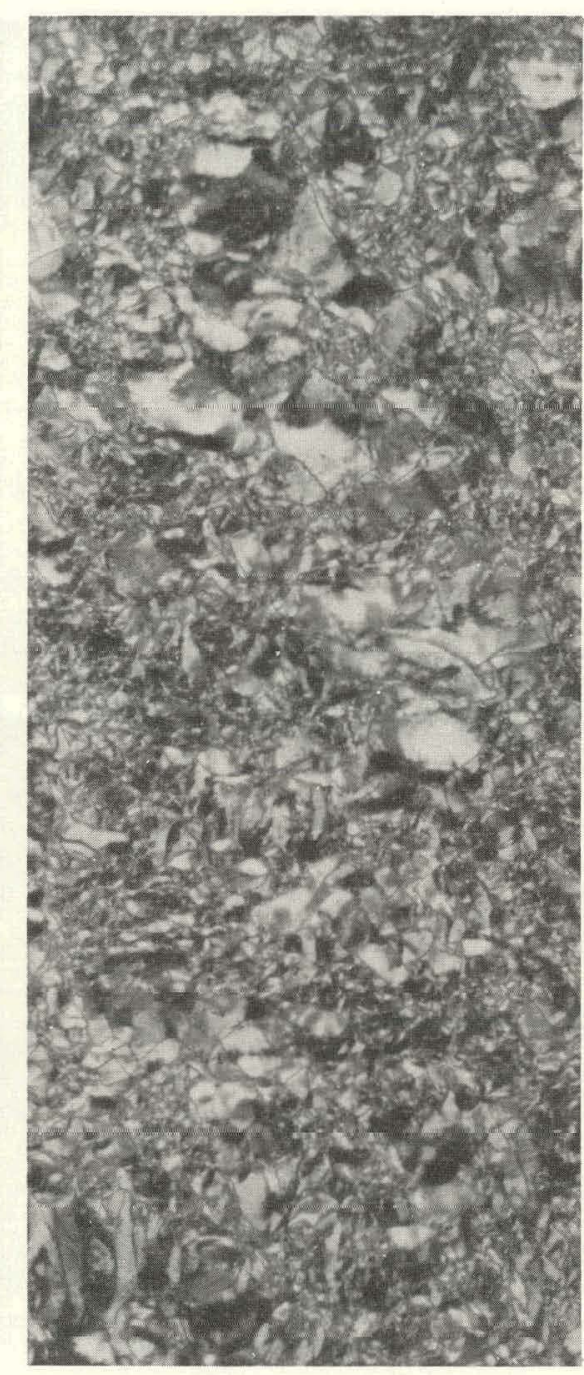

(b) $20 \% \mathrm{FAl}$.

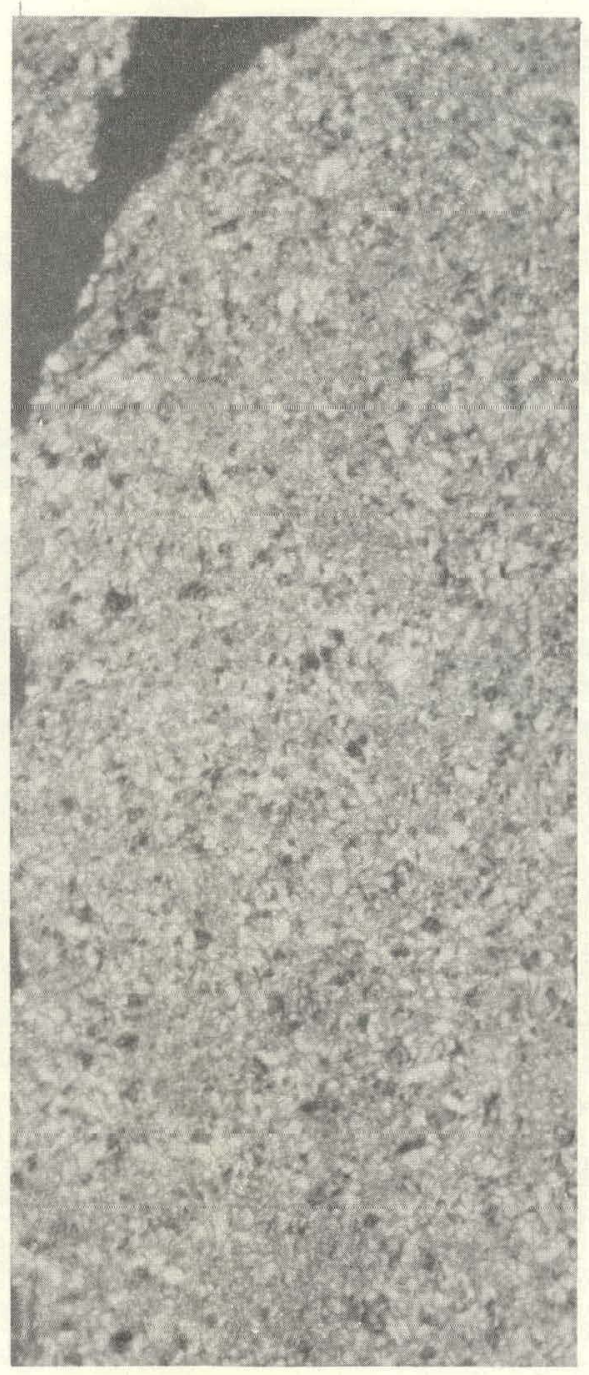

(c) $40 \% \mathrm{FAl}$.

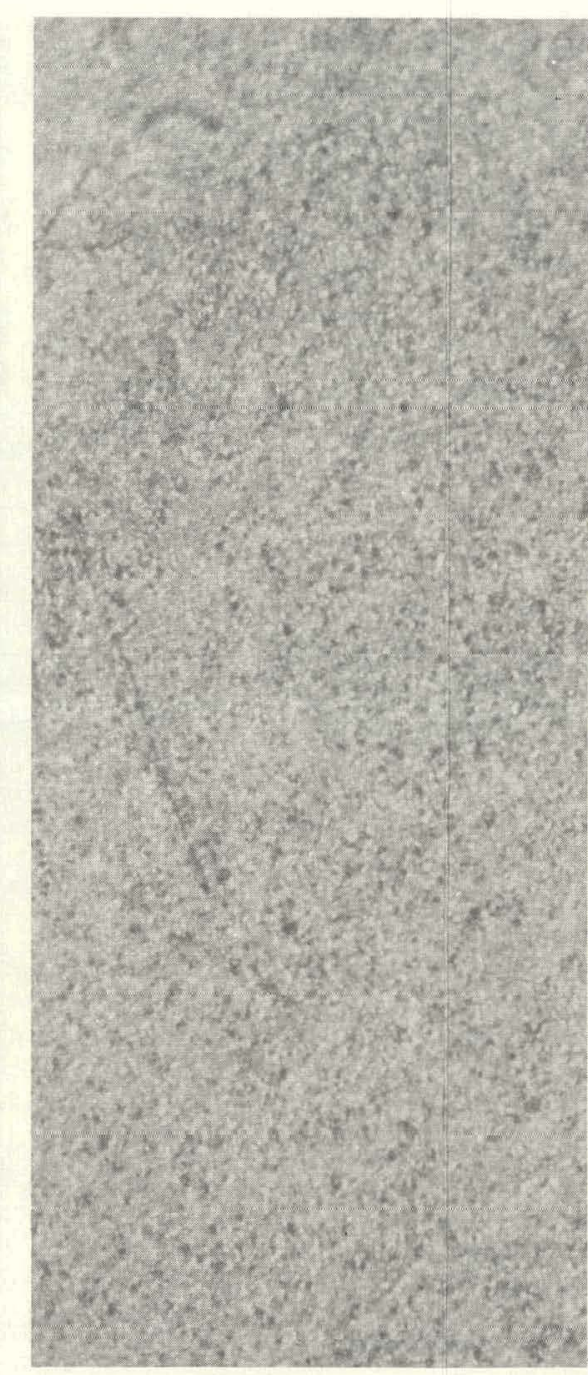

(d) $50 \% \mathrm{FAl}$.

Figure 11. MICROSTRUCTURES OF CARBONS (AFTER 2,800 C) DERIVED FROM CINNAMYLIDENEINDENE/FURFURYLIDENEINDENE MIXTURES. (Sensitive Tint: $250 x$ ) 


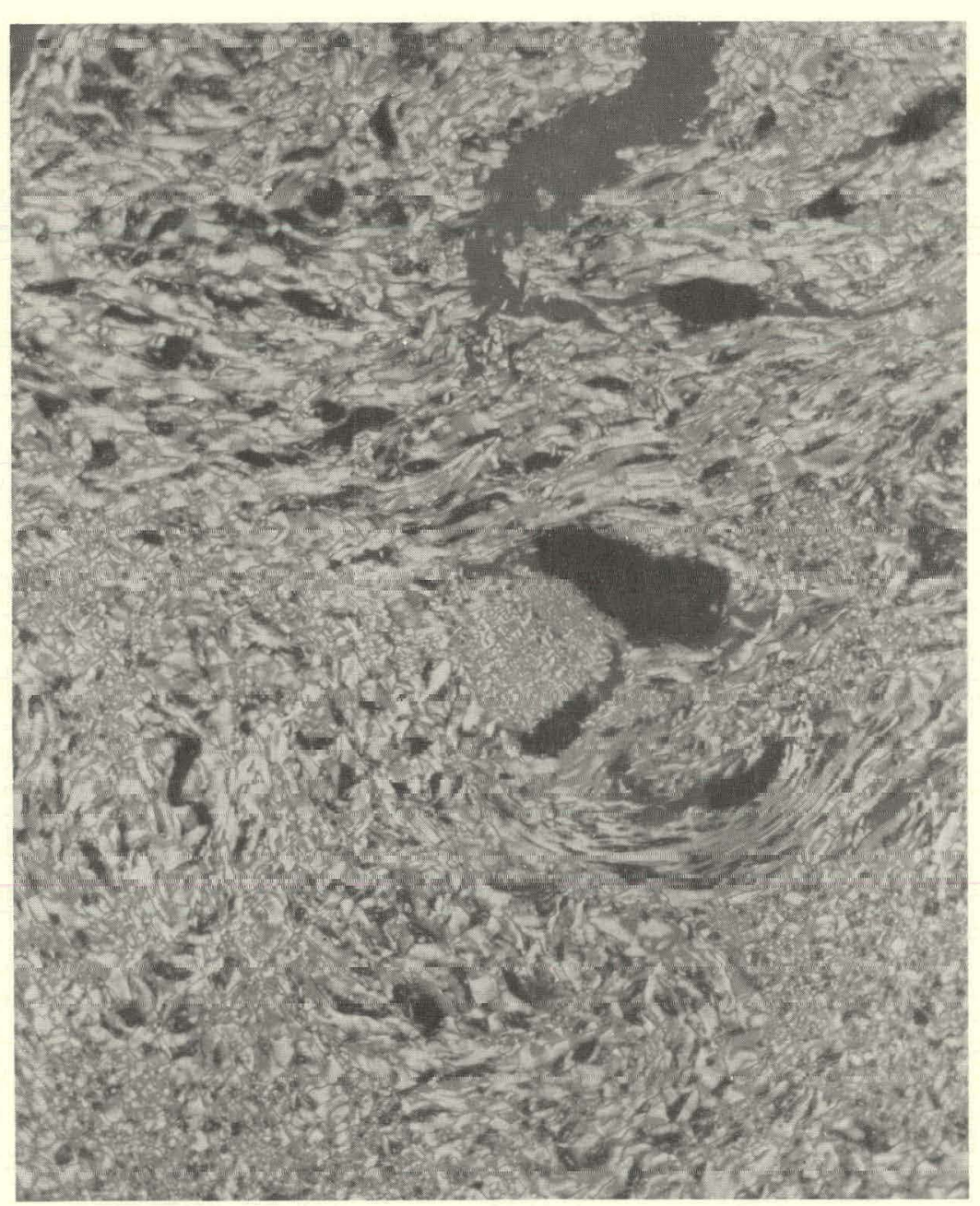

(a) $50 \% \mathrm{FAl}$.

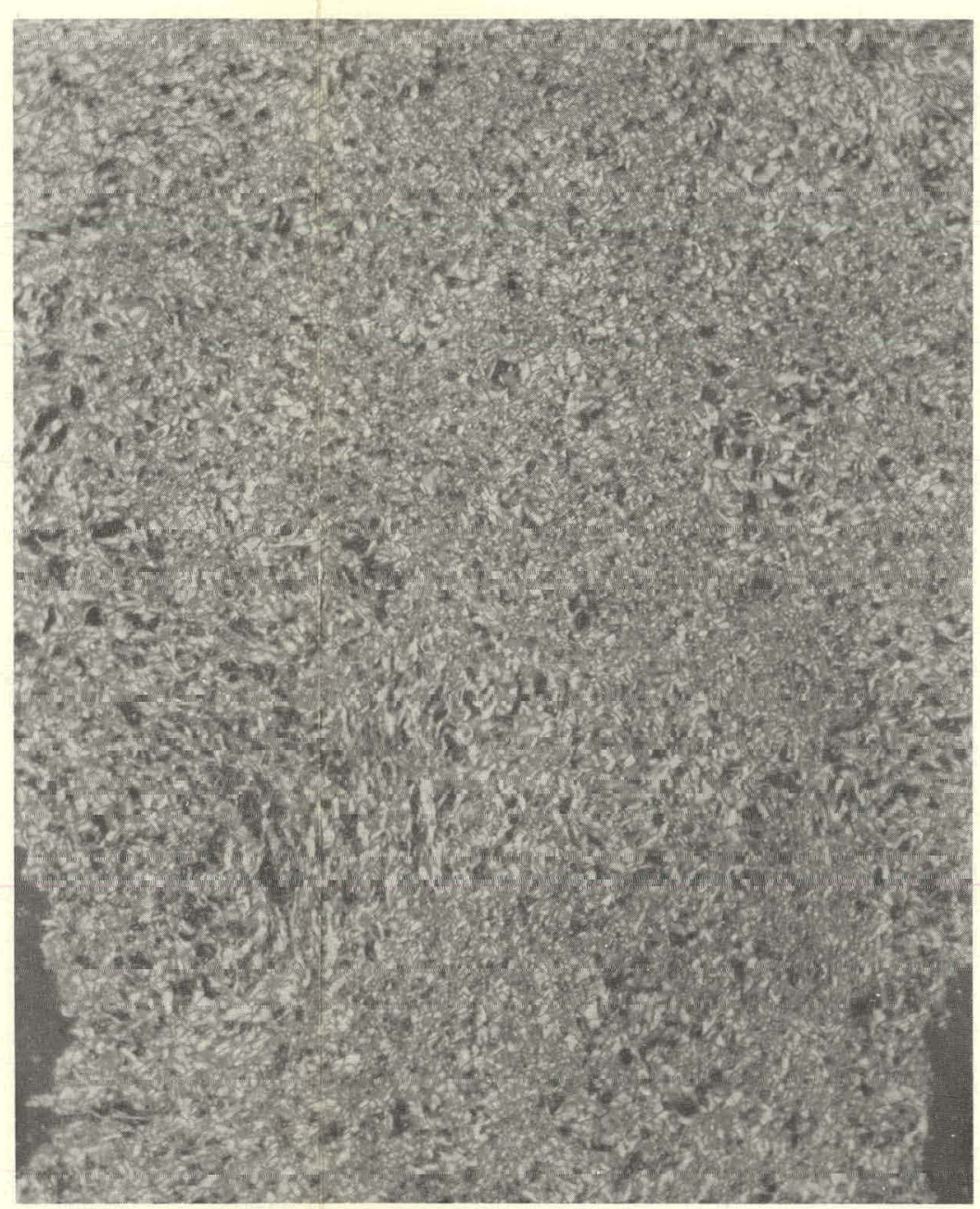

$193-5$ (b) $60 \%$ FAl.

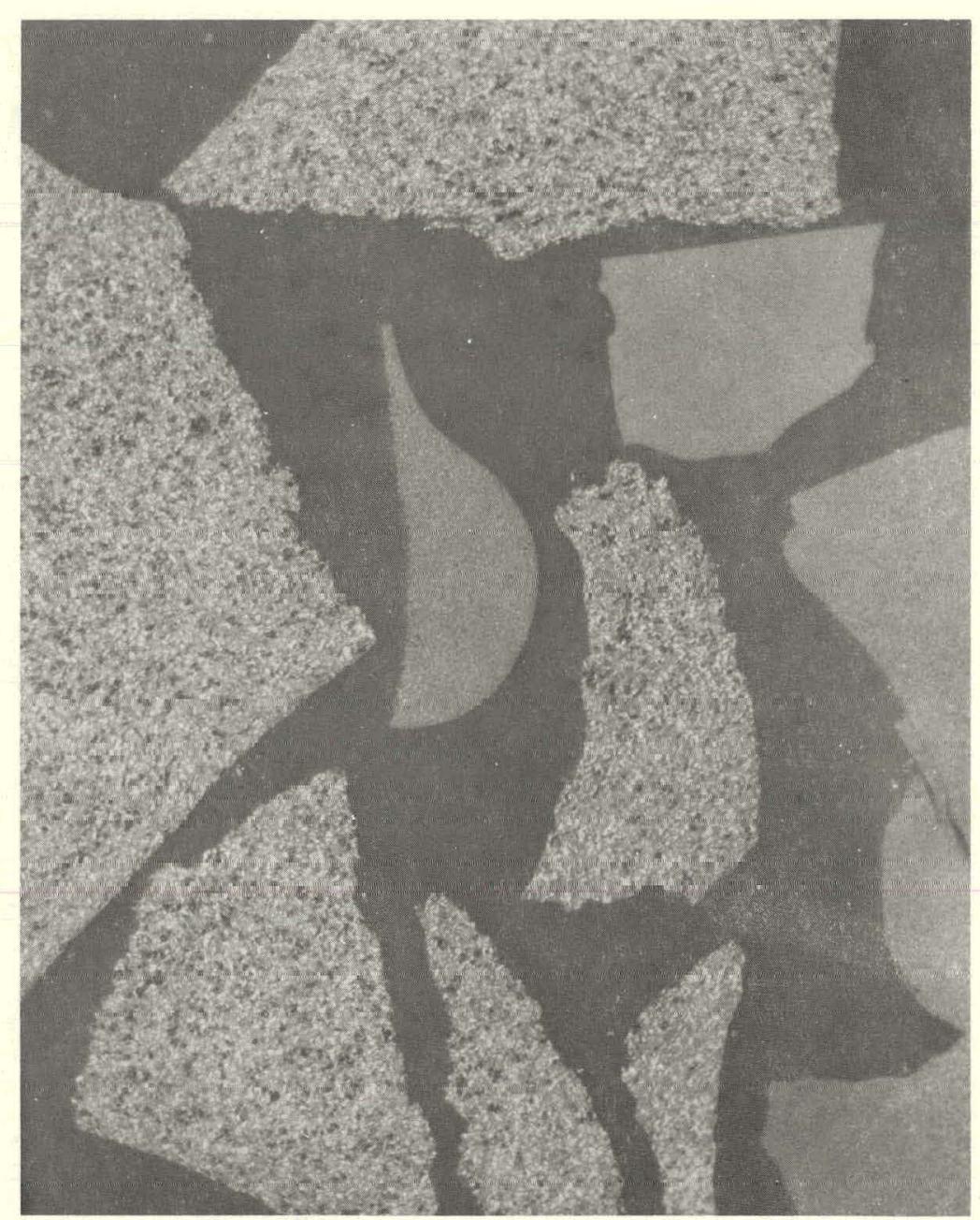

(c) $70 \%$ FAI.

Figure 12. MICROSTRUCTURES OF CARBON (AFTER $2,800^{\circ} \mathrm{C}$ ) DERIVED FROM LARGE BATCHES OF CINNAMYLIDENEINDENE/FURFURYLIDENEINDENE MIXTURES. (Sensitive Tint; 250X) 


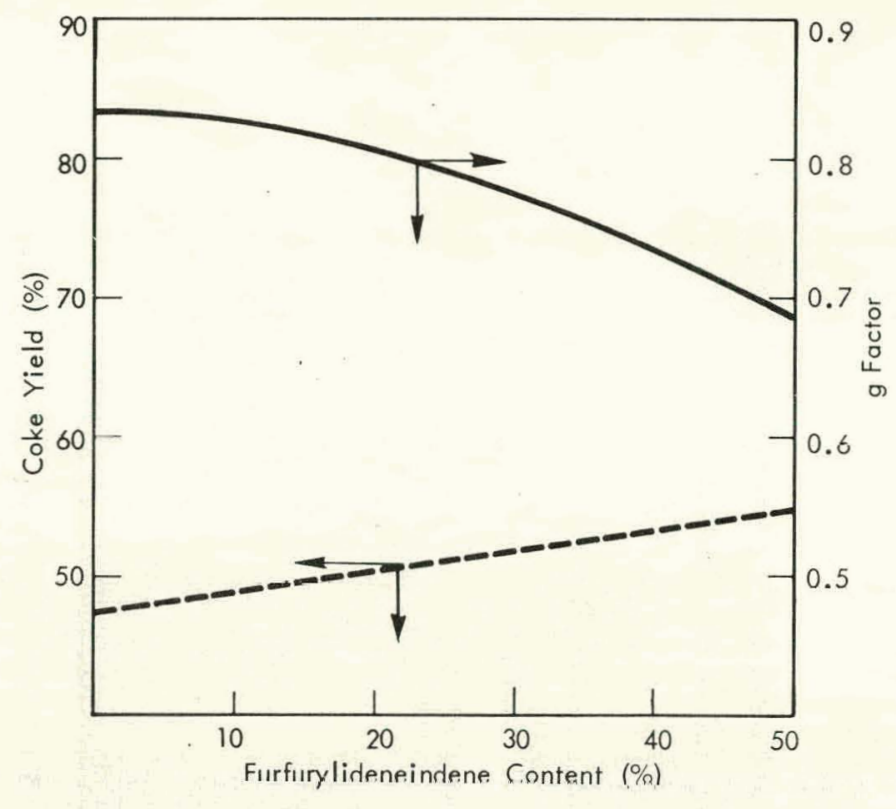

Figure 13. PROPERTIES OF CARBONS DERIVED FROM MIXTURES OF FURFURYLIDENEINDENE AND POLYMERIC CINNAMYLIDENEINDENE AS FUNCTIONS OF THE FURFURYLIDENEINDENE CONTENT.

use of CAI-340, a decreased reactivity of FAI with CAI-340 was expected. Since the effects were similar to each other, little copolymerization of the two materials must occur, although the two materials remain miscible in each other.

The relationship between carbon properties and the chemistry of the polymeric precursor system can be better illustrated by examining the data obtained from the autoclave polymerization of CAI and FAI.

Blends of CAI and FAl were autoclaved for two hours at $300^{\circ} \mathrm{C}$ and an initial (room-temperature) nitrogen pressure of 300 psi. Properties of the resulting polymers and derived carburs are listed in Table 6. Figure 15 contains a composite GPC scan showing the variation in molecular distribution as the FAl content was varied. As the FAl content increased, the average molecular size increased, which is indicative of an increased degree of crosslinking to form higher-molecular-weight entities. Average-molecular-weight values, shown in Figure 16, reenforce the argument that higher-molecular-weight entities are formed, in that the average molecular weights of the polymers increased steadily as the FAI content increased. Ring-and-ball softening points of the polymers increased rapidly due to the increased concentration of the higher-molecular-weight components.

As would be expected, oxygen contents of the polymers increased as the FAl content increased. As noted with the polymers, properties of carbon derived from these polymers correspond to the graduated change from a thermoplastic to a thermosetting polymer system. Coke yields after $1,000^{\circ} \mathrm{C}$ increased steadily as the $\mathrm{FAl}$ content increased. Crystallite-size and g-factor values obtained for the $2,800^{\circ} \mathrm{C}$ carbons decreased as the $\mathrm{FAl}$ content incrcascd, further indicating a trend to a more crosslinked and/or nonplanar system. 

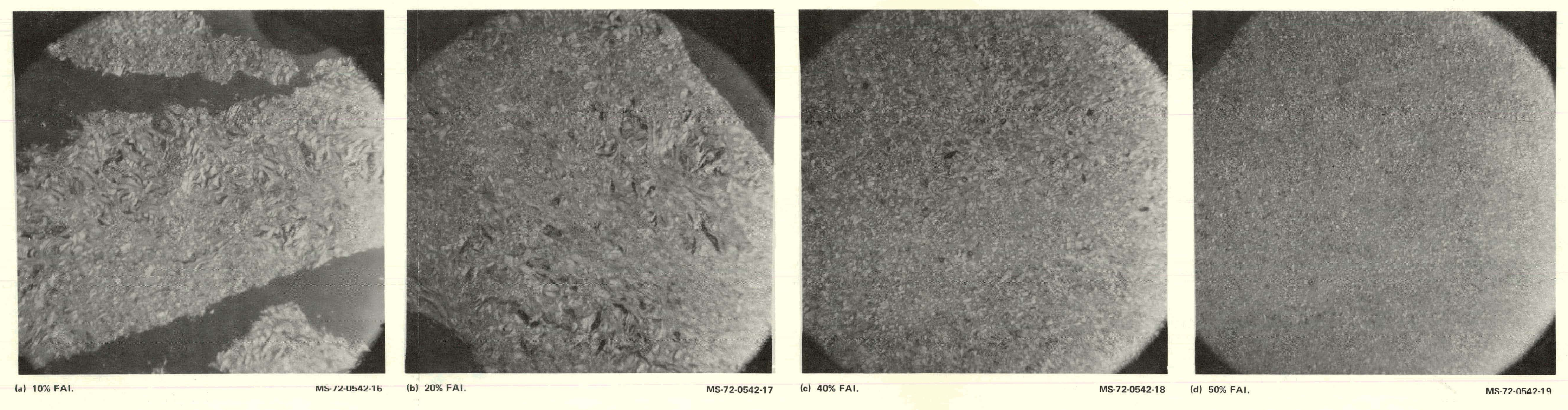

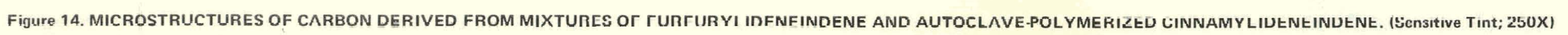


Table 6

PROPERTIES OF POLYMERS PREPARED BY AUTOCLAVING MIXTURES OF CINNAMYLIDENEINDENE AND FURFURYLIDENEINDENE

\begin{tabular}{|c|c|c|c|c|c|c|c|c|}
\hline \multirow[b]{3}{*}{ Sample(1) } & \multirow{3}{*}{$\begin{array}{c}\text { FAI } \\
\text { Content } \\
(\%)\end{array}$} & \multirow{3}{*}{$\begin{array}{l}\text { Softening } \\
\text { Point } \\
\text { (O C) }\end{array}$} & \multirow{3}{*}{$\begin{array}{c}\text { Polymer } \\
\text { Average } \\
\text { Molecular } \\
\text { Weight }(2)\end{array}$} & \multirow{3}{*}{$\begin{array}{c}\text { Oxygen } \\
\text { Content (3) } \\
(\%)\end{array}$} & \multirow{3}{*}{$\begin{array}{c}\text { Coke } \\
\text { Yield (4) } \\
(\%)\end{array}$} & \multirow{2}{*}{\multicolumn{3}{|c|}{ Carbon Data (5) }} \\
\hline & & & & & & & & \\
\hline & & & & & & $\begin{array}{l}d_{002} \\
\text { (A) }\end{array}$ & $\begin{array}{c}L_{c} \\
\text { (A) }\end{array}$ & g Factor \\
\hline A & 0 & 50 & 421 & 0.66 & 44 & 3.3662 & 230 & 0.858 \\
\hline B & 25 & 85 & 555 & 2.01 & 47 & 3.3656 & 127 & 0.865 \\
\hline $\mathrm{C}$ & 50 & 125 & 663 & 2.99 & 53 & 3.3816 & 106 & 0.679 \\
\hline D & 75 & 195 & 856 & 4.47 & 61 & 3.3916 & 73 & 0.563 \\
\hline $\mathrm{E}$ & 100 & & (6) & 5.65 & 75 & 3.4148 & 70 & 0.293 \\
\hline
\end{tabular}

(1) Samples autoclaved for two hours at $300^{\circ} \mathrm{C}$ and 300 psi (initial $\mathrm{N}_{2}$ pressure).

(2) Determined by vapor pressure osmometry.

(3) Determined by neutron activation.

(4) Carbonized in an open, four-inch-diameter boat and in an argon atmosphere on a programmed cycle to $2,800^{\circ} \mathrm{C}$. Samples contained 30 grams of polymer.

(5) Obtained after heating for one hour at $2,800^{\circ} \mathrm{C}$.

(6) Sample contained 79 percent insolubles, making molecular weight determination biased.

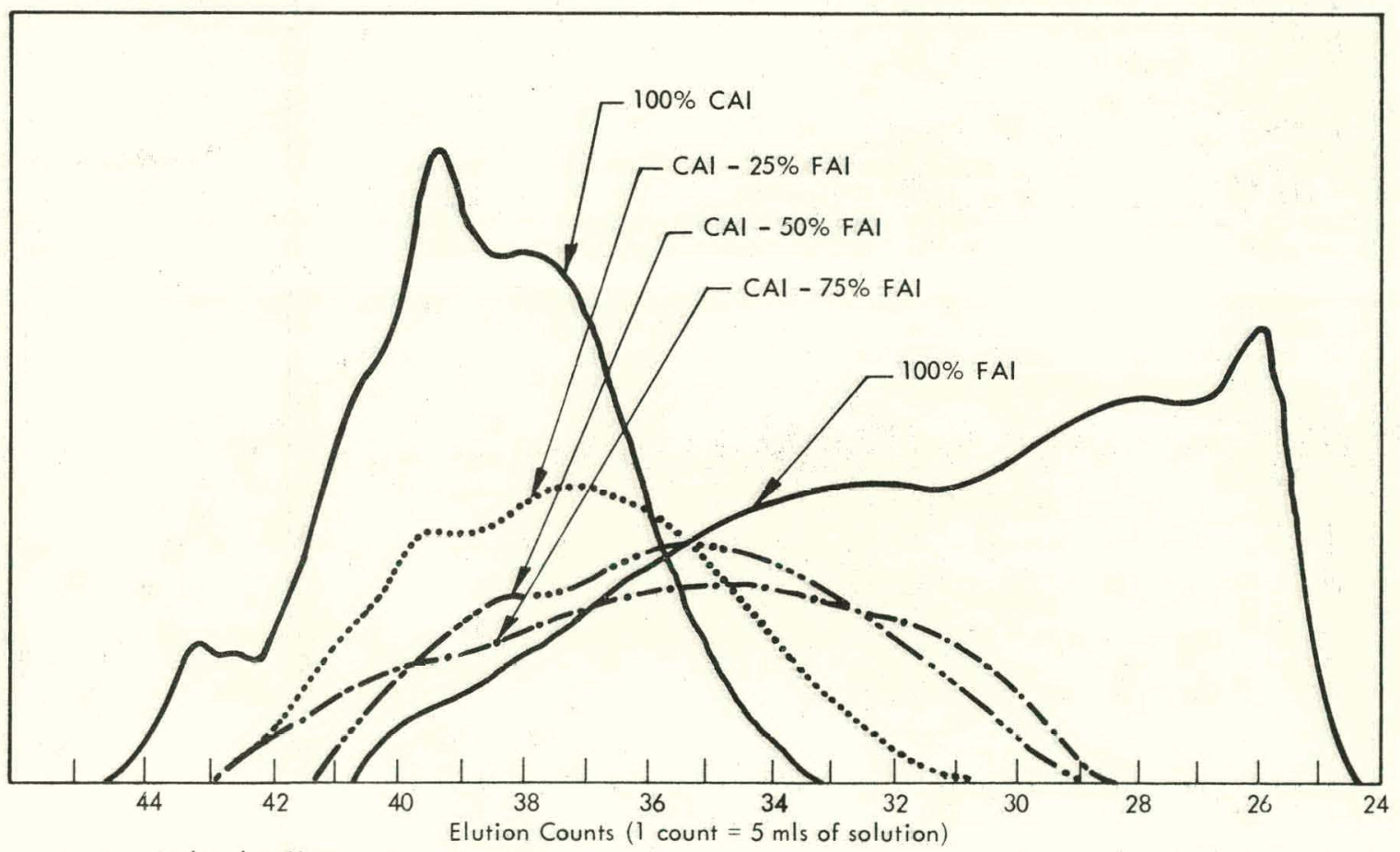

Increasing Molecular Size $\longrightarrow$

Figure 15. GEL PERMEATION CHROMATOGRAPHIC SCANS OF AUTOCLAVE-PRODUCED POLYMERS OF CINNAMYLIDENEINDENE AND FURFURYLIDENEINDENE.

Microstructures of the $2,800^{\circ} \mathrm{C}$ carbons, shown in Figure 17, also indicated a graduated decrease in carbon crystallinity as the FAl content increased. Thus, the crystallinity changes 

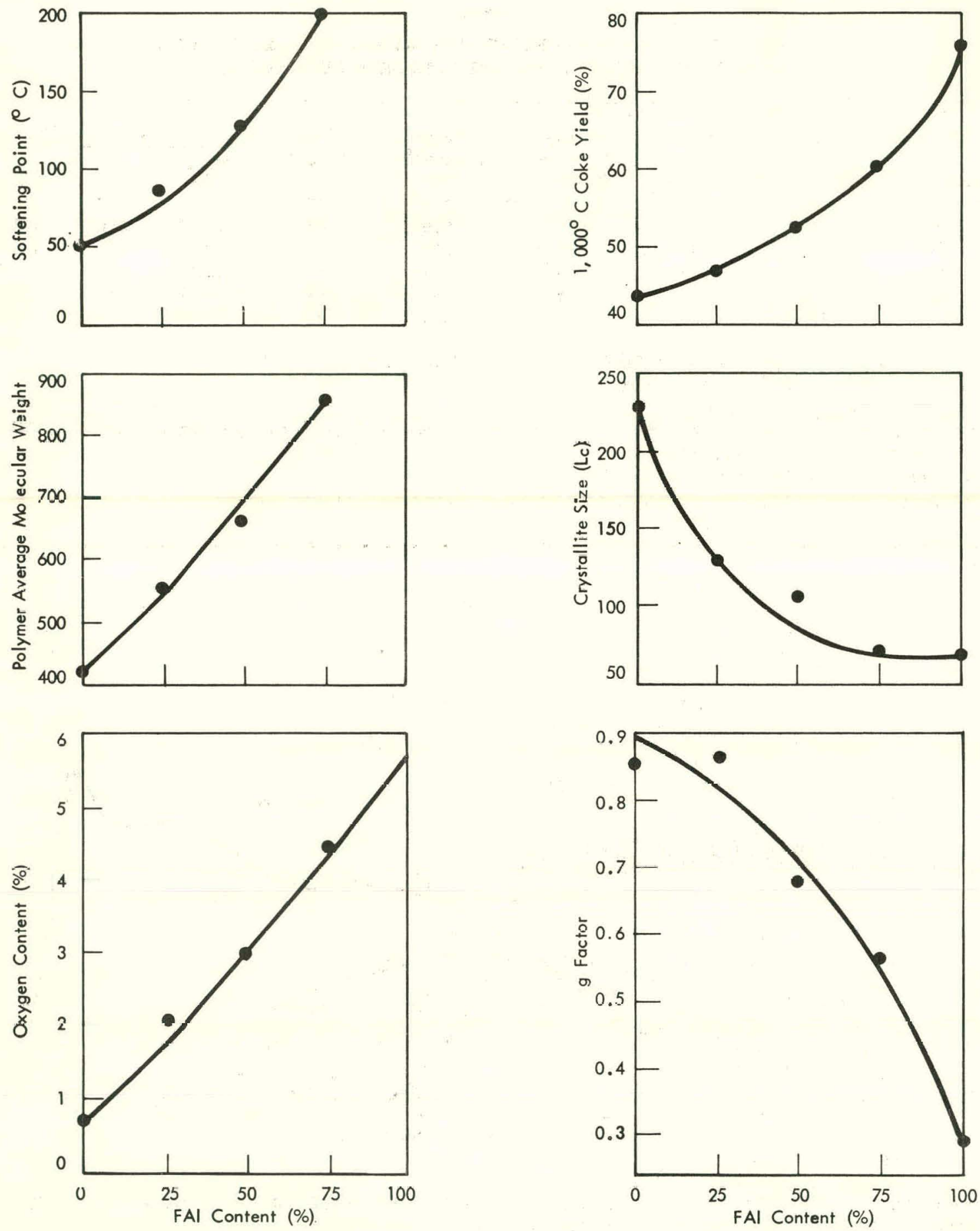

(a) Polymers.

(b) Carbon.

Figure 16. PROPERTIES OF AUTOCLAVED BLENDS OF CINNAMYLIDENEINDENE AND FURFURYLIDENEINDENE.

from a highly crystalline, heterogeneous structure typical of the CAI-derived carbon to a noncrystalline structure typical of the FAI-derived carbon. 


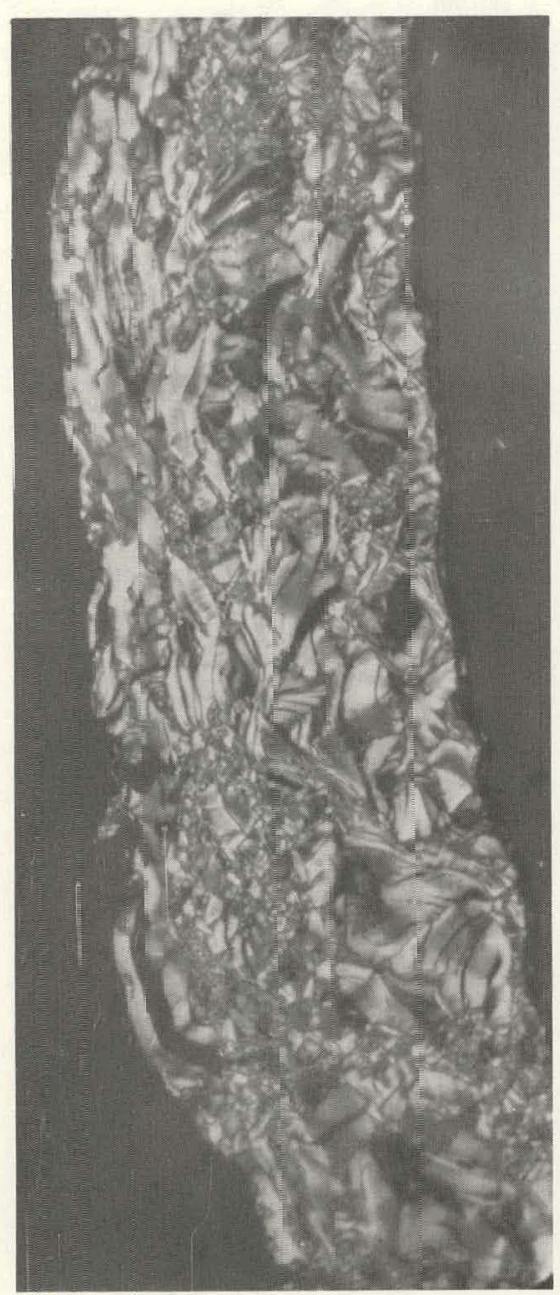

(a) c\% FAl.

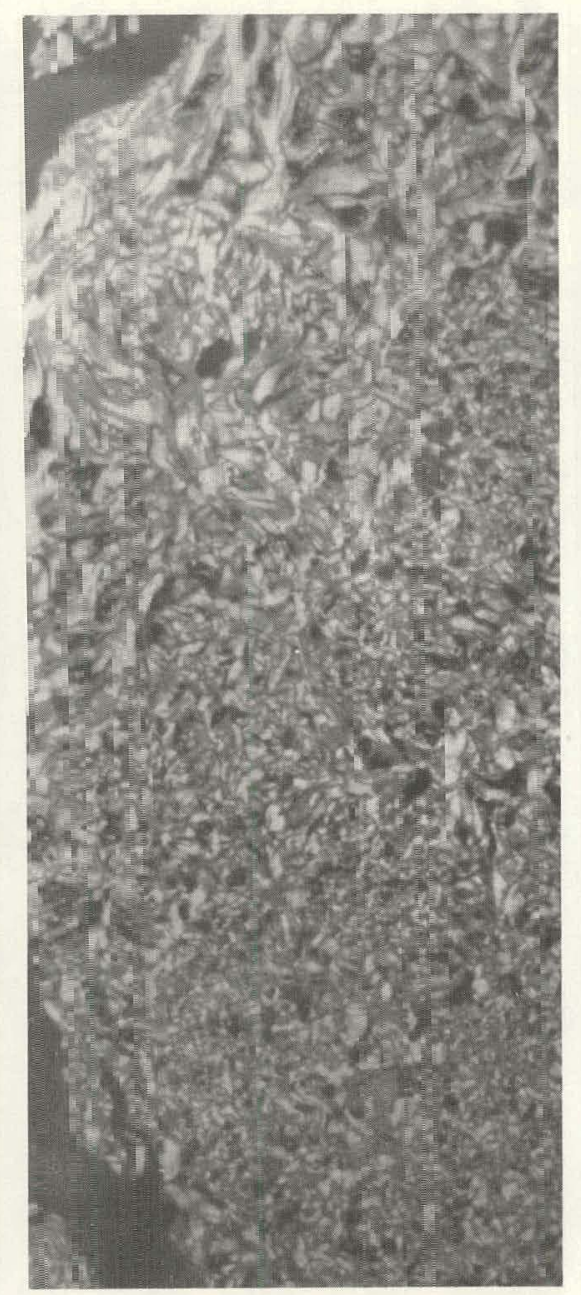

(b) $25 \%$ FAI.

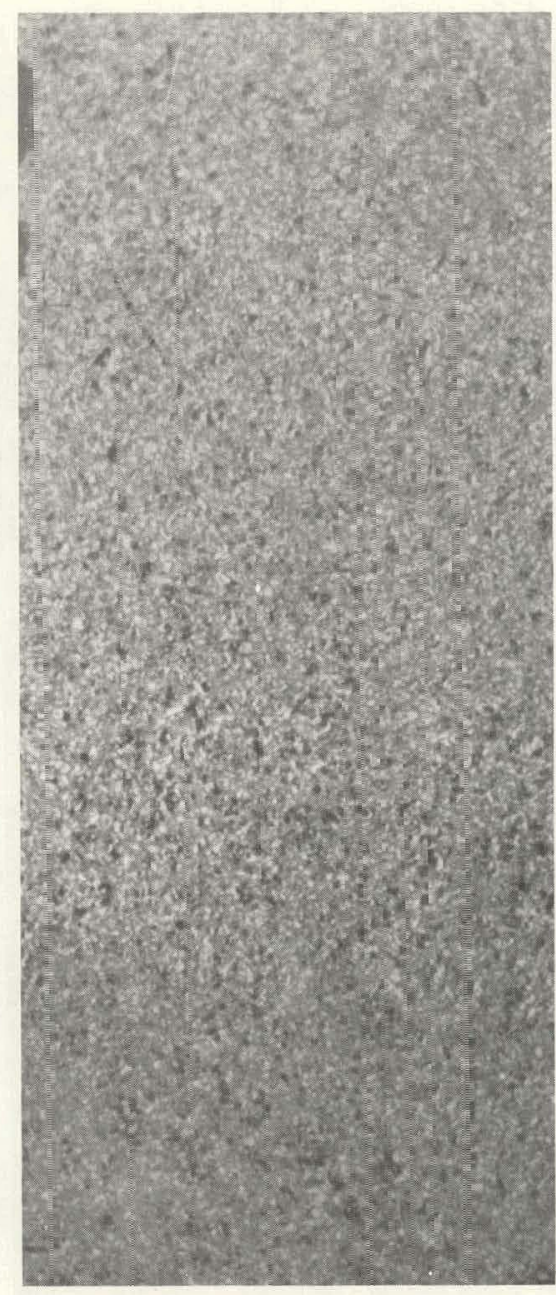

(c) $50 \%$ FAI.

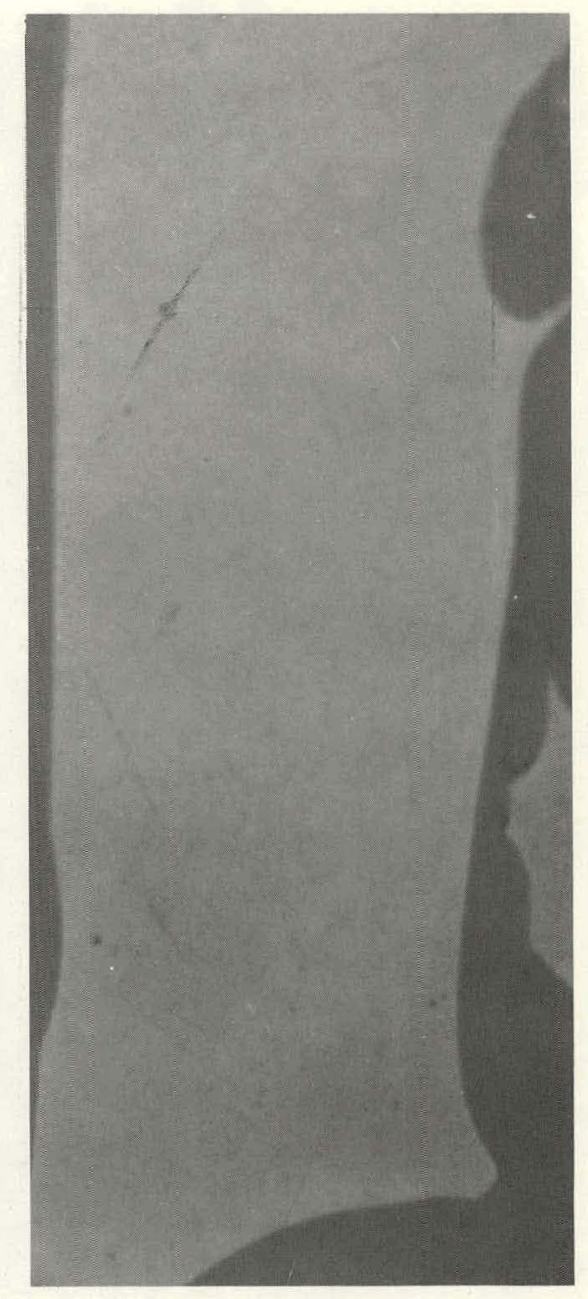

(d) $75 \% \mathrm{FAl}$. 
In summation, addition of FAl to $\mathrm{CAI}$ and $\mathrm{ACN}$ allows for control of properties of the respective derived carbons.

\section{Properties of Carbons Derived from Blends of Acenaphthylene and Cinnamylideneindene with $\mathbf{p}$-Xylylideneindene}

The high degree of conjugation present in p-xylylideneindene (XYN) results in crosslinking characteristics which hinder molecular mobility in the stages prior to pyrolysis and thus produces a thermosetting rather than a thermoplastic material. Consequently, upon heating to $1,000^{\circ} \mathrm{C}$ and subsequent firing at $2,800^{\circ} \mathrm{C}$, a noncrystalline carbon is obtained from $X Y N$. Efforts to control the properties of the carbons led to the copolymerization of ACN and $\mathrm{CAI}$ with $\mathrm{XYN}$ in order to utilize the potential crosslinking character of $X Y N$. Data obtained for the blends are listed in Table 7.

Table 7

PROPERTIES OF CARBONS DERIVED FROM MIXTURES OF ח-XYI YI II IINEIINDENE WITH CINNAMYLIDENEINDENE AND ACENAPHTHYLENE

\begin{tabular}{|c|c|c|c|c|c|}
\hline \multirow[b]{2}{*}{ Sample } & \multirow{2}{*}{$\begin{array}{c}\text { XYN } \\
\text { Content } \\
(\%)\end{array}$} & \multirow{2}{*}{$\begin{array}{c}\text { Coke } \\
\text { Yield (1) } \\
(\%)\end{array}$} & \multicolumn{3}{|c|}{ X-Ray Diffraction Data (2) } \\
\hline & & & $\begin{array}{c}\mathrm{d}_{002} \\
\text { (A) }\end{array}$ & $\begin{array}{l}L_{c} \\
\text { (A) }\end{array}$ & $\mathrm{g}$ Factor \\
\hline \multicolumn{6}{|c|}{ Cinnamylideneindene } \\
\hline A & 0 & 37 & 3.3582 & 114 & 0.951 \\
\hline B & 10 & 38 & 3.3668 & 147 & 0.851 \\
\hline $\mathrm{C}$ & 20 & 44 & 3.3708 & 79 & 0.805 \\
\hline D & 30 & 44 & 3.3730 & 70 & 0.779 \\
\hline $\mathrm{E}$ & 40 & 48 & 3.3782 & 63 & 0.719 \\
\hline $\mathrm{F}$ & 50 & 53 & 3.3834 & 67 & 0.658 \\
\hline G & 60 & 56 & 3.3846 & 57 & 0.644 \\
\hline \multicolumn{6}{|c|}{ Acenaphthylene } \\
\hline A & 0 & 30 & 3.3622 & 385 & 0.905 \\
\hline B & 10 & 37 & 3.3662 & 305 & 0.858 \\
\hline C & 20 & 42 & 3.3712 & 180 & 0.798 \\
\hline D & 30 & 45 & 3.3690 & 204 & 0.826 \\
\hline $\mathrm{F}$ & 40 & 49 & 3.3668 & 270 & 0.851 \\
\hline $\mathrm{F}$ & 50 & 51 & 3.3684 & 218 & 0.833 \\
\hline G & 60 & 54 & 3.3650 & 201 & 0.872 \\
\hline $\mathrm{H}$ & 70 & 55 & 3.3764 & 126 & 0.740 \\
\hline 1 & 80 & 57 & 3.3834 & 98 & 0.668 \\
\hline
\end{tabular}

(1) Obtained after heating to $1,000^{\circ} \mathrm{C}$ in an inert atmosphere.

(2) Obtained after firing for one hour at $2,800^{\circ} \mathrm{C}$.

Acenaphthylene/p-Xylylideneindene Mixtures - Coke yields of carbons derived from ACN/XYN blends increased steadily as the XYN content increased to 80 percent (Figure 18 ), while $g$ factors of the corresponding $2,800^{\circ} \mathrm{C}$ carbons were more erratic. The crystallinity decreased to an apparent minimum as the $X Y N$ content increased from 0 to 20 percent and increased somewhat in the composition range corresponding to 30 to 60 percent $X Y N$. Compositions containing greater than 60 percent $X Y N$ rapidly decreased in crystallinity. 


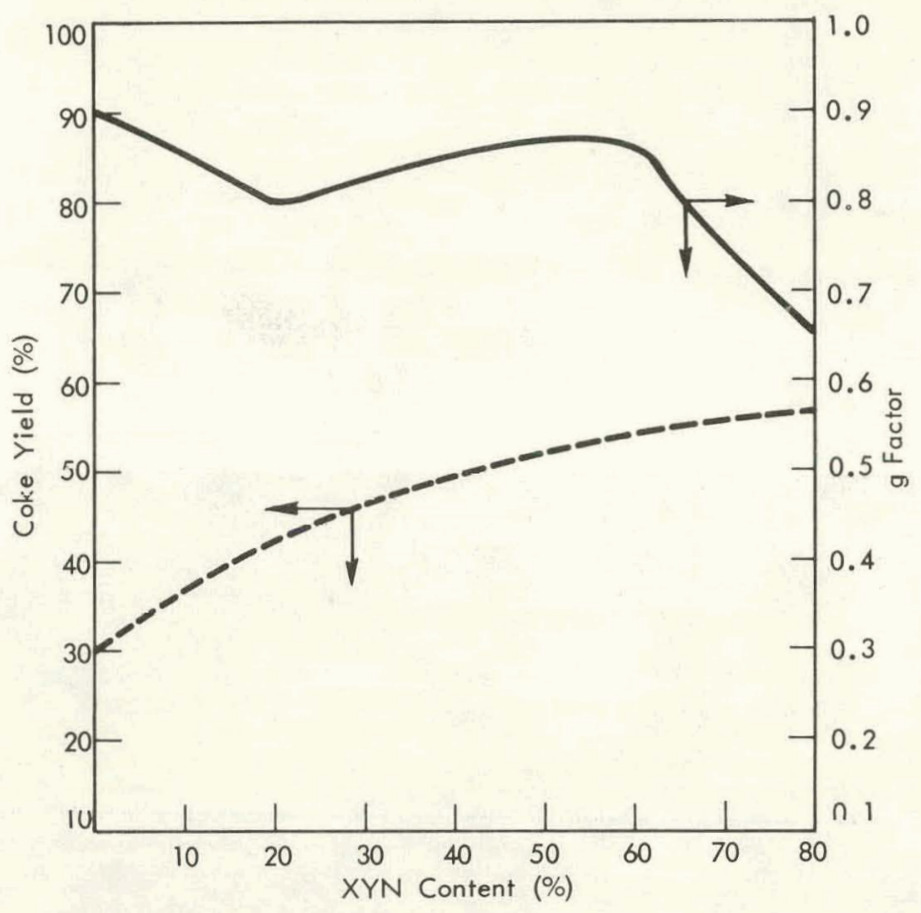

Figure 18. PROPERTIES OF CARBONS DERIVED FROM ACENAPHTHYLENE/p-XYLYLIDENEINDENE MIXTURES AS FUNCTIONS OF THE p-XYLYLIDENEINDENE CONTENT.

Microstructures shown in Figure 19 also reveal the transition in crystallinity with increasing $X Y N$ content. A subtle decrease in crystallinity was evident as the $X Y N$ content increased from 10 to 50 percent, while increasing the $X Y N$ content 70 to 80 percent resulted in carbons with a significant decrease in crystallinity.

The gradual increase in coke yields as the XYN content increased implied a gradual increase in the crosslinked character of the precursor blend. However, X-ray data revealed that the degree of crosslinking and/or nonplanarity in the precursor during polymerization and/or pyrolysis was erratic for XYN concentrations lower than 60 percent. For higher concentratiuns ( $70 \%$ or greater), the degrec of crosslinking and/or nonplanarity appeared to increase rapidly as the $\mathrm{XYN}$ content increased.

Cinnamylideneindene/p-Xylylideneindene Mixtures - As noted in Figure 20, coke yields of CAI/XYN blends increased steadily as the XYN content increased, while the degree of graphiticity decreased gradually with increasing $X Y N$. Thus, the degree of crosslinking in the $\mathrm{CAI} / \mathrm{XYN}$ precursor system must be increasing with increasing $\mathrm{XYN}$ content.

Microstructures of the $2,800^{\circ} \mathrm{C}$ carbons, shown in Figure 21, revealed a gradual decrease in carbon crystallinity from a highly crystalline carbon typical of CAI to a fine-grain, homogeneous carbon as the XYN content increased from 0 to 50 percent.

Copolymerization of the CAI/XYN blends apparently include enough miscibility of one precursor in the other to allow the thermosetting character of $X Y N$ to decrease the molccular reorientations necessary to produce carbon of high graphiticity. Thus, the $\mathrm{CAI}$ XYN system affords carbon which has reproducible and controllable properties. 

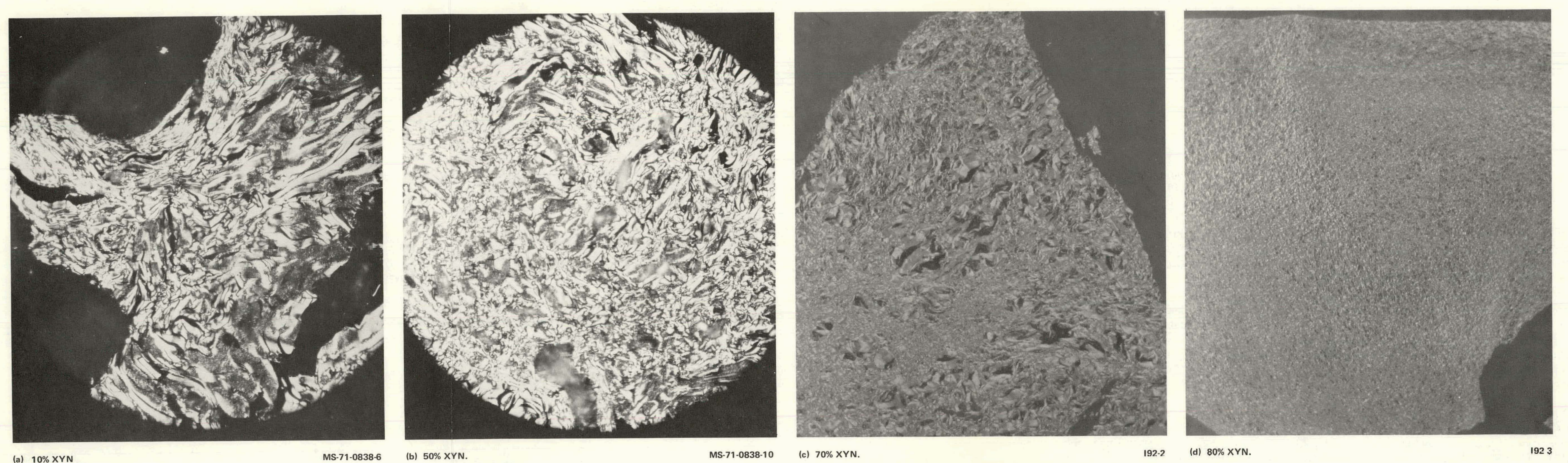

(a) $10 \% \mathrm{XYN}$

MS-71-0838.6 (b) $50 \%$ XYN

MS-71-0838-10 (c) $70 \% \times r$.

192.2 (d) $80 \% \mathrm{XYN}$.

Figure 19. MICROSTRUCTURES OF CARBONS (AFTER 2,800 C) DERIVED FROM ACENAPHTHYLENE/Q-XYLYLIDENEINDENE MIXTURES. (Sensitive Tint: 250X) 


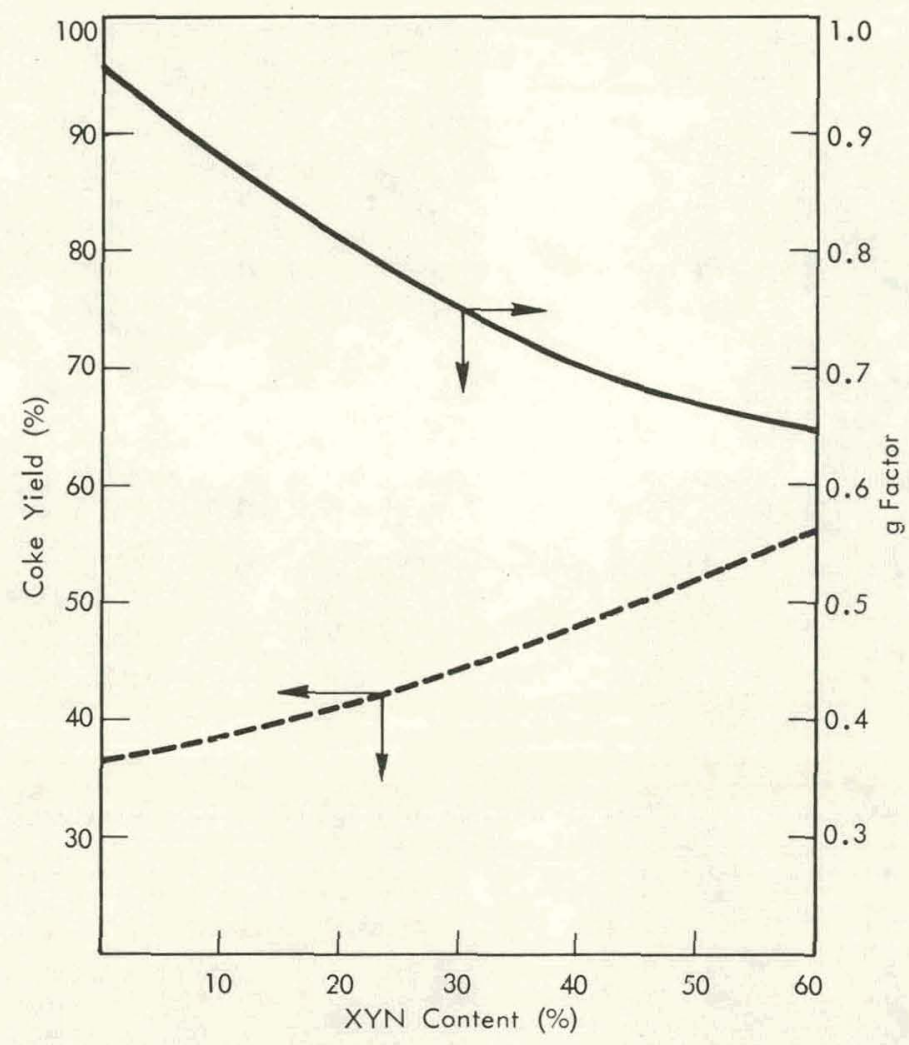

Figure 20. PROPERTIES OF CARBONS DERIVED FROM CINNAMYLIDENEINDENE/p-XYLYLIDENEINDENE MIXTURES AS

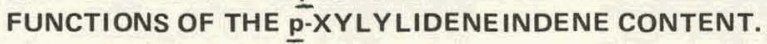

\section{Properties of Carbons Derived from Blends of Acenaphthylene and Cinnamylideneindene with Isotruxene}

Isotruxene (ITX), which yields a carbon of low graphiticity, was blended with CAI and ACN in efforts to alter the properties of the highly graphitic carbons derived from these two precursors. Carbon data obtained from these blends are listed in Table 8.

Acenaphthylene/Isotruxene Mixtures - Coke yields of carbons derived from the ACN/ITX mixtures, and coked without a prior air cure, varied only slightly as the ITX content in the blend increased (Figure 22), while coke yields of the air-cured samples increased rapidly for blends containing greater than 40 percent ITX. As also indicated in Figure 22, the graphiticity of the corresponding $2,800^{\circ} \mathrm{C}$ carbons decreased slowly as the ITX content increased. Air-cured samples were of a higher order of graphiticity than samples coked without an air cure.

Microstructural transitions, shown in Figure 23, reflect the decrease in graphiticity as the ITX content increased in blends coked without an air cure. Samples decreased in crystallinity from highly crystalline carbon typical of $A C N$ to a somewhat fine-grain, less-crystalline carbon typical of ITX. As expected from an examination of Figure 22, microstructures of carbons derived from air-cured ITX/ACN mixtures revealed little change in crystallinity as the ITX content increased (Figure 24). 


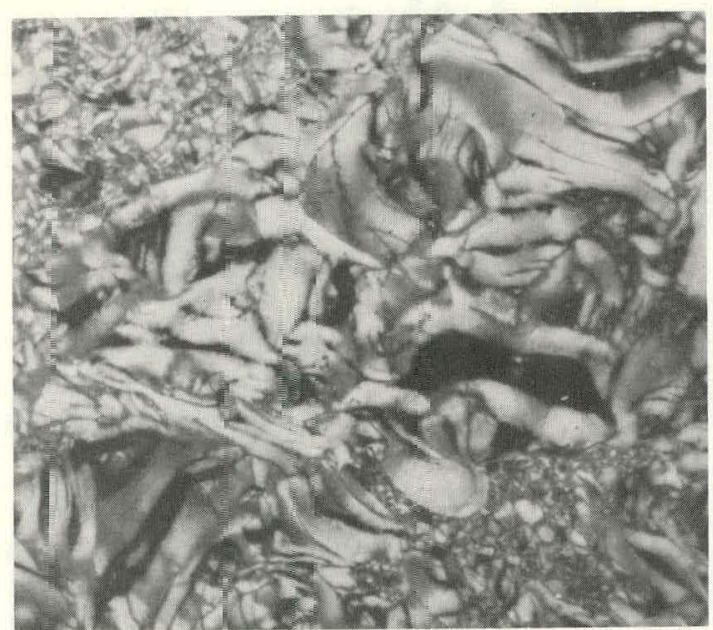

(a) $0 \% \times Y N$.

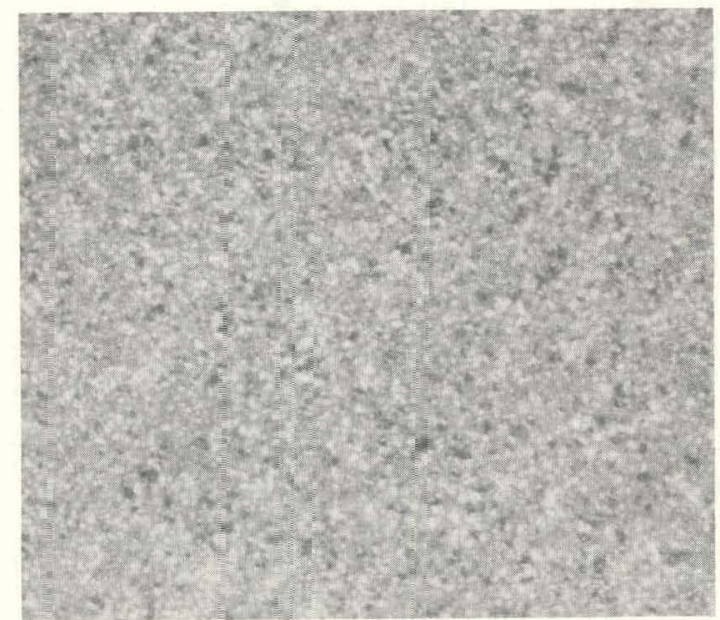

(d) $30 \% X Y N$.

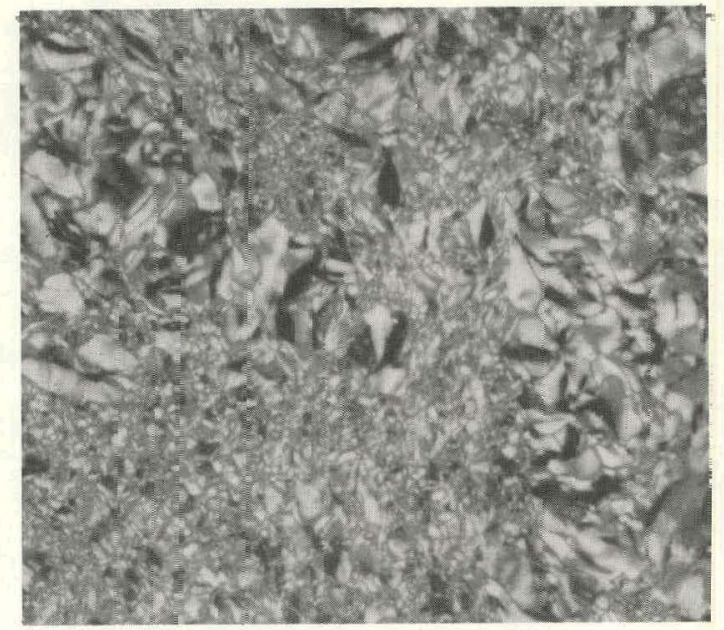

(b) $10 \% \times Y v$.

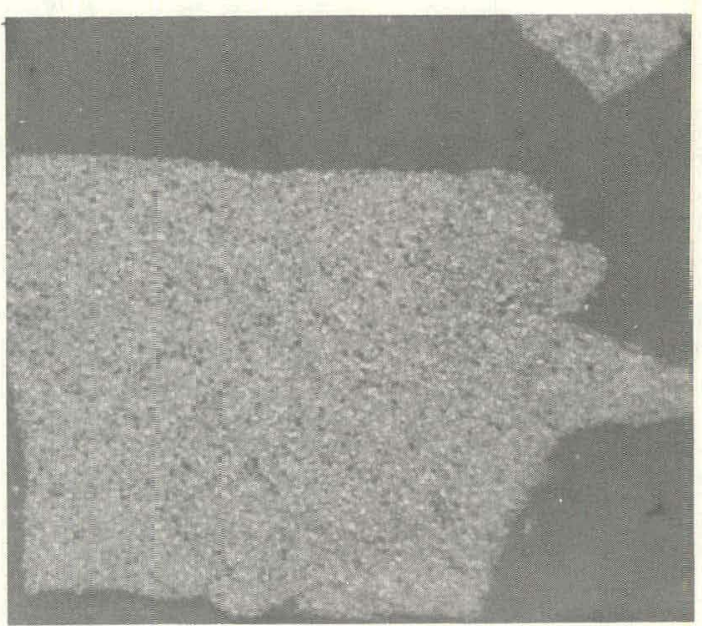

(e) $40 \% \mathrm{XYN}$.

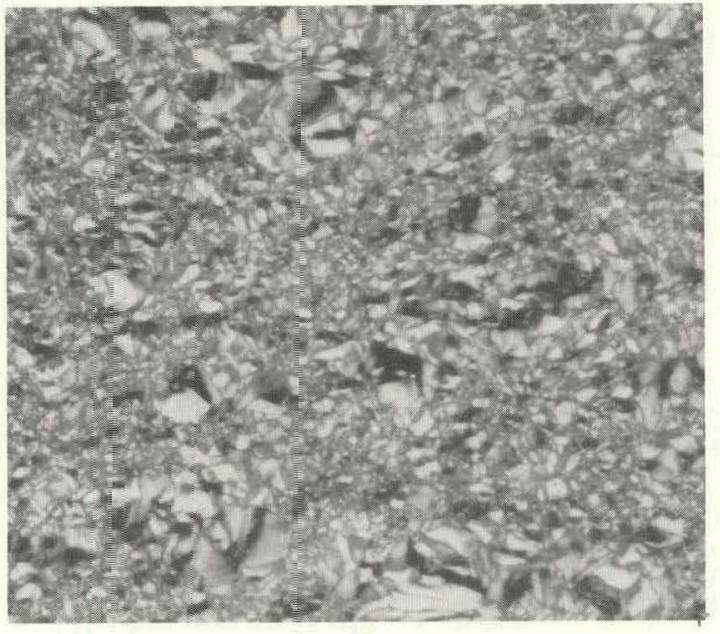

(c) $20 \% X Y N$.

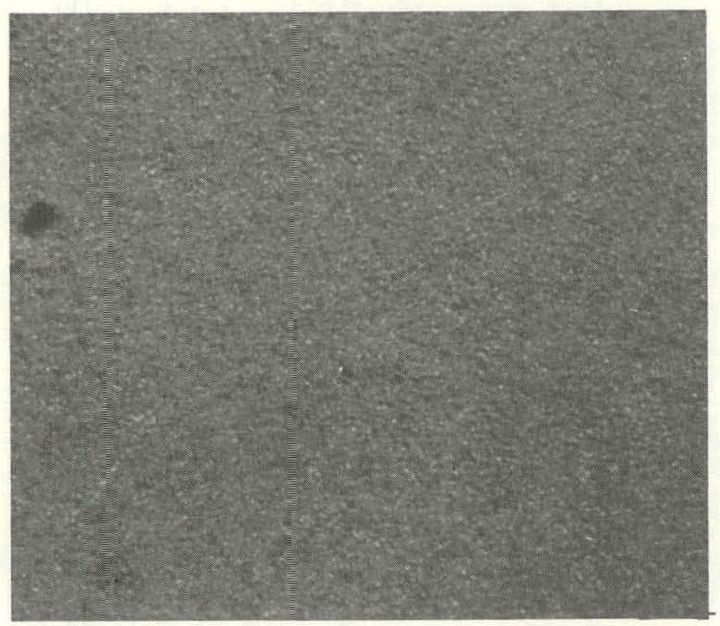

(f) $50 \% X Y N$.

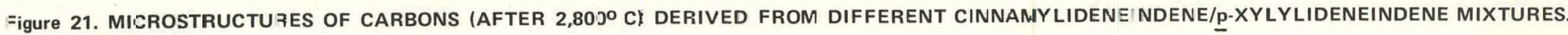
Sensitive Tint: 250X 
Table 8

PROPERTIES OF CARBON DERIVED FROM MIXTURES OF ISOTRUXENE WITH CINNAMYLIDENEINDENE AND ACENAPHTHYLENE

\begin{tabular}{|c|c|c|c|c|c|c|c|c|c|}
\hline \multirow[b]{3}{*}{ Sample } & \multirow{3}{*}{$\begin{array}{c}\text { ITX } \\
\text { Content } \\
(\%)\end{array}$} & \multirow{2}{*}{\multicolumn{2}{|c|}{ Coke Yield (\%) }} & \multicolumn{6}{|c|}{ Carbon Data } \\
\hline & & & & \multicolumn{3}{|c|}{ With an Air Cure } & \multicolumn{3}{|c|}{ Without an Air Cure } \\
\hline & & $\begin{array}{l}\text { With an } \\
\text { Air Cure }\end{array}$ & $\begin{array}{l}\text { Without an } \\
\text { Air Cure }\end{array}$ & $\begin{array}{l}\mathrm{d}_{002} \\
\text { (A) }\end{array}$ & $\begin{array}{l}\mathrm{L}_{\mathrm{C}} \\
\text { (A) }\end{array}$ & g Factor & $\begin{array}{l}\mathrm{d}_{002} \\
\text { (A) }\end{array}$ & $\begin{array}{l}\mathrm{L}_{\mathrm{c}} \\
\text { (A) }\end{array}$ & g Factor \\
\hline \multicolumn{10}{|c|}{ Cinnamylideneindene } \\
\hline A & 0 & 46 & 36 & 3.3708 & 154 & 0.805 & 3.3678 & 215 & 0.840 \\
\hline B & 10 & - & 38 & - & - & - & 3.3650 & 152 & 0.872 \\
\hline C & 15 & - & 37 & - & - & - & 3.3668 & 212 & 0.851 \\
\hline D & 20 & 45 & 38 & 3.3752 & 125 & 0.753 & 3.3662 & 196 & 0.858 \\
\hline E & 25 & - & 37 & - & - & - & 3.3628 & 160 & 0.898 \\
\hline $\mathrm{F}$ & 40 & 48 & 41 & 3.3628 & 380 & 0.898 & 3.3622 & 342 & 0.905 \\
\hline G & 60 & 53 & 38 & 3.3628 & 365 & 0.898 & 3.3616 & 383 & 0.912 \\
\hline $\mathrm{H}$ & 80 & 58 & 38 & 3.3622 & 395 & 0.905 & 3.3764 & 106 & 0.740 \\
\hline 1 & 100 & 60 & 36 & 3.3640 & 271 & 0.884 & 3.3758 & 121 & 0.747 \\
\hline \multicolumn{10}{|c|}{ Acenaphthylene } \\
\hline A & 0 & 30 & 30 & 3.3588 & $>1,000$ & 0.944 & 3.3588 & 807 & 0.944 \\
\hline B & 20 & 30 & 31 & 3.3594 & 640 & 0.937 & 3.3594 & 723 & 0.937 \\
\hline $\mathrm{C}$ & 40 & 31 & 32 & 3.3600 & 398 & 0.930 & 3.3594 & 521 & 0.937 \\
\hline D & 60 & 42 & 31 & 3.3604 & 560 & 0.926 & 3.3622 & 350 & 0.905 \\
\hline$E$ & 80 & 54 & 34 & 3.3628 & 289 & 0.898 & - & - & - \\
\hline $\mathrm{F}$ & 100 & 60 & 36 & 3.3640 & 271 & 0.884 & 3.3758 & 121 & 0.747 \\
\hline
\end{tabular}

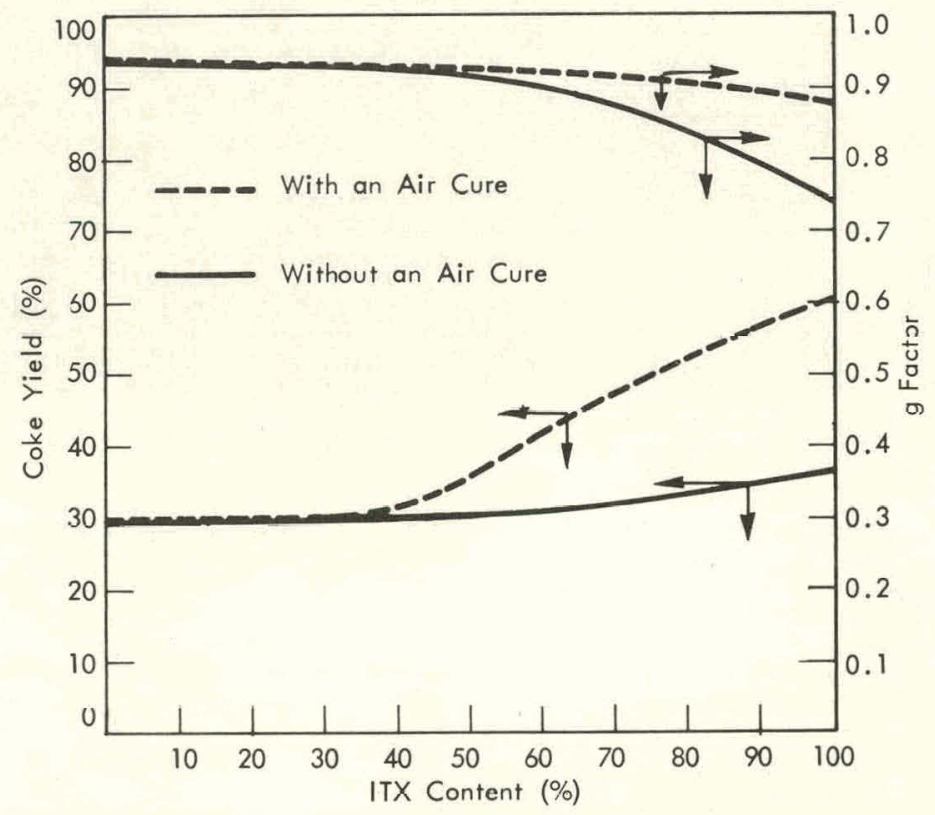

Figure 22. PROPERTIES OF CARBONS DERIVED FROM ACENAPHTHYLENE/ISOTRUXENE MIXTURES AS FUNCTIONS OF THE ISOTRUXENE CONTENT. 


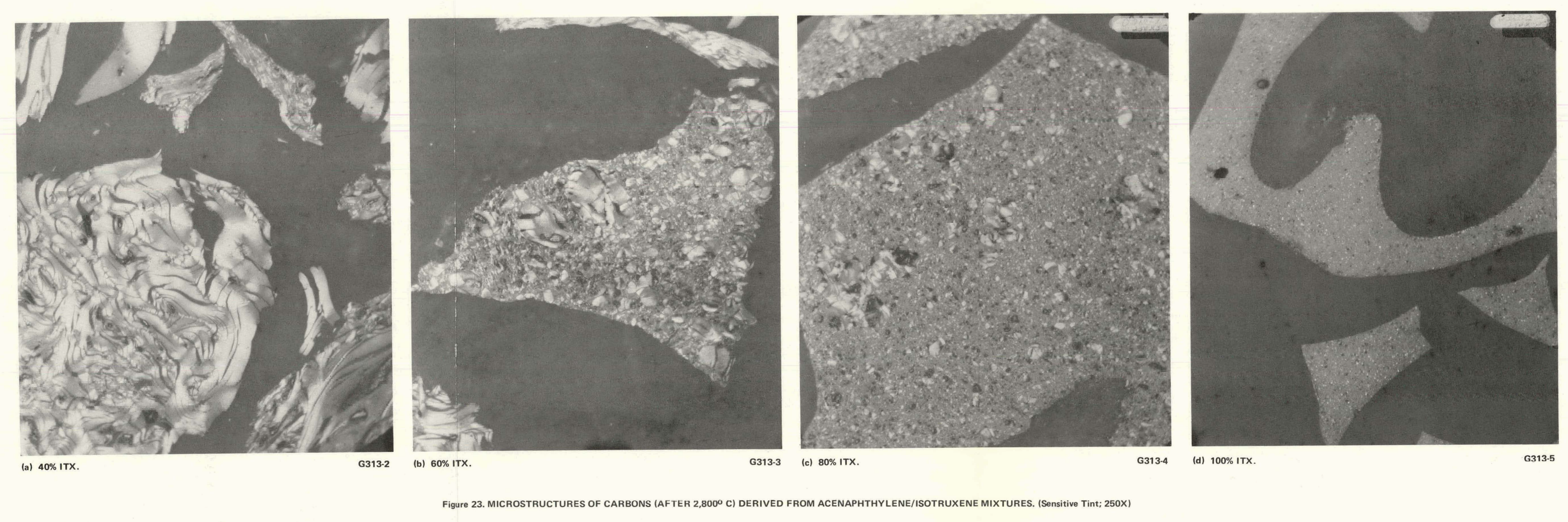




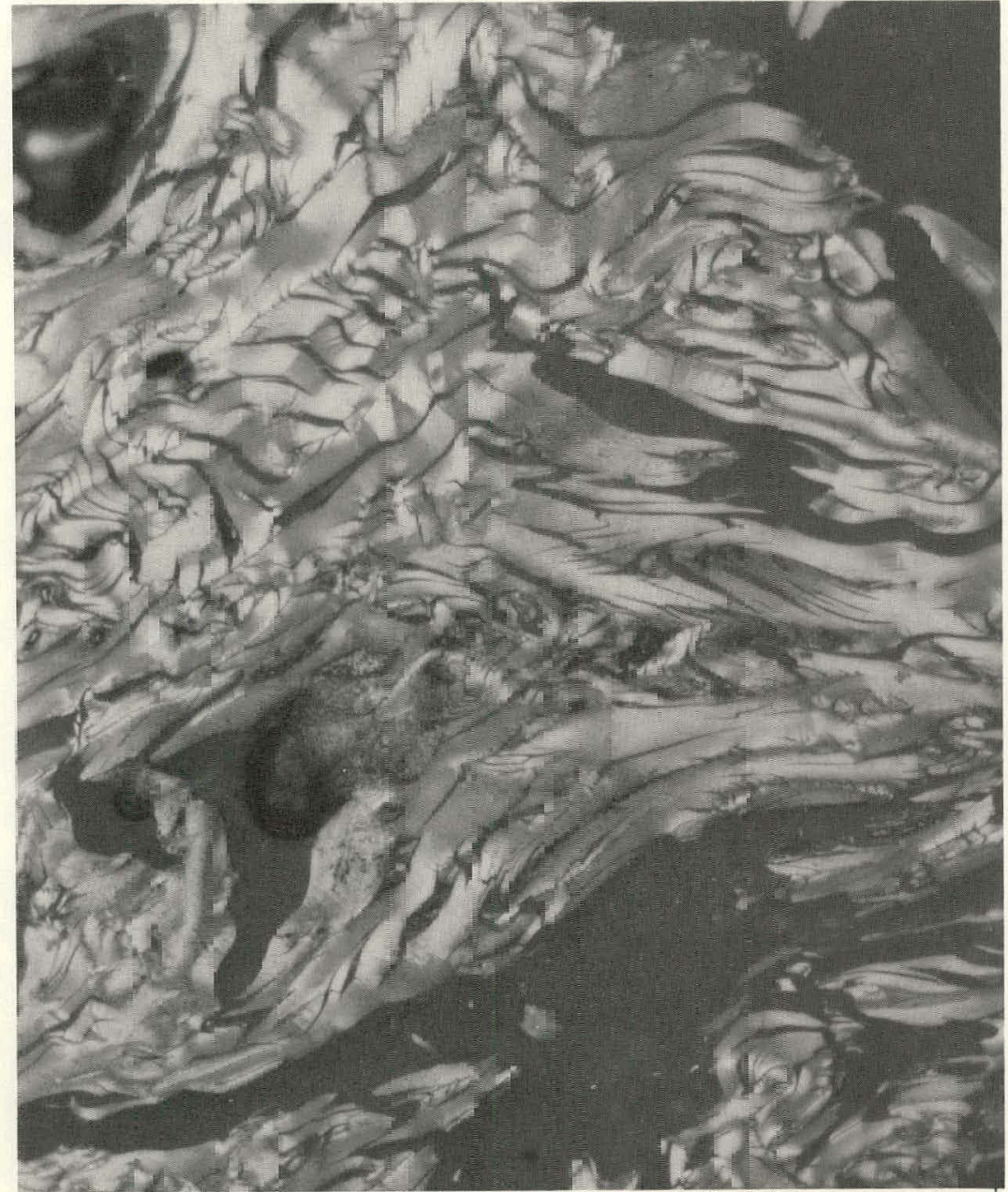

(a) $20 \% \mathrm{rTX}$.

G314-1

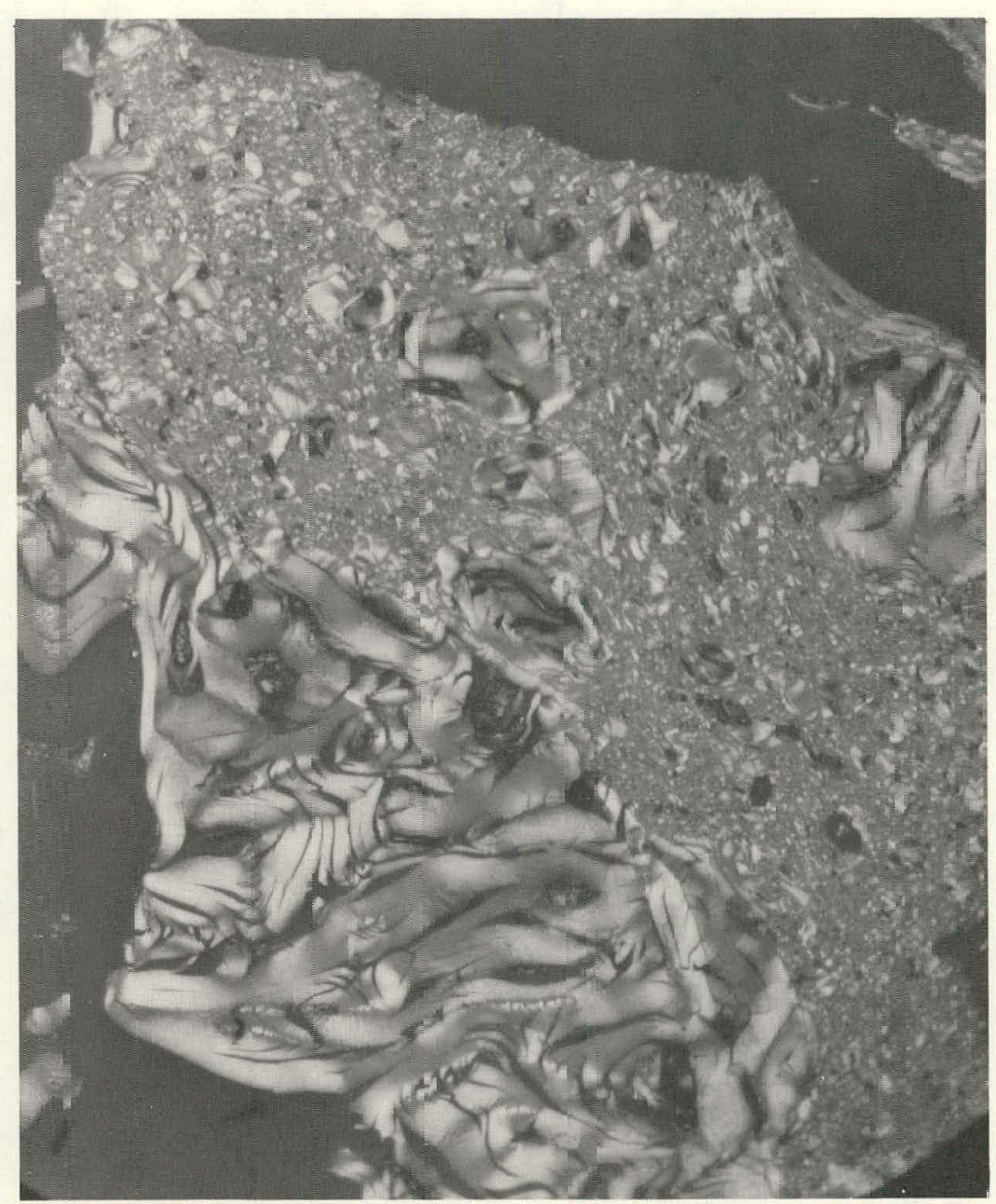

'b' $\mathbf{B 0} \%$ ITX.

G314-4

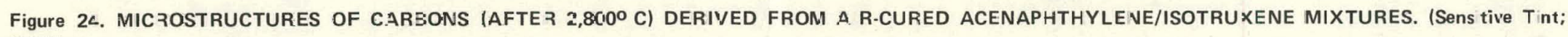
250X) 
Thus, air curing blends of ITX/ACN affords a method of increasing the coke yield while altering the graphitic properties only slightly. Samples coked without an air cure yield changing graphitic properties and little change in coke yield as the ITX content in the blends increased.

Cinnamylideneindene/Isotruxene Mixtures - Properties of carbons derived from CAI/ITX blends are illustrated as a function of their ITX content in Figure 25. Coke yields of the air-cured sample increased with increasing ITX content, while coke yields of the uncured samples were essentially constant with composition. Corresponding g factors reveal a transition in graphiticity with changing composition. This transition occurred over a relatively narrow composition range for both air-cured and uncured samples. However, the specific composition at which the transition occurred differed with the cure conditions. Thus, the transition occurred over a composition range corresponding to samples containing 60 to 80 percent ITX for uncured samples, while a transition in the air-cured samples occurred at compositions corresponding to 20 to 40 percent ITX. Fur bullı cured and uncured samples, changes at other compositions were minimal.

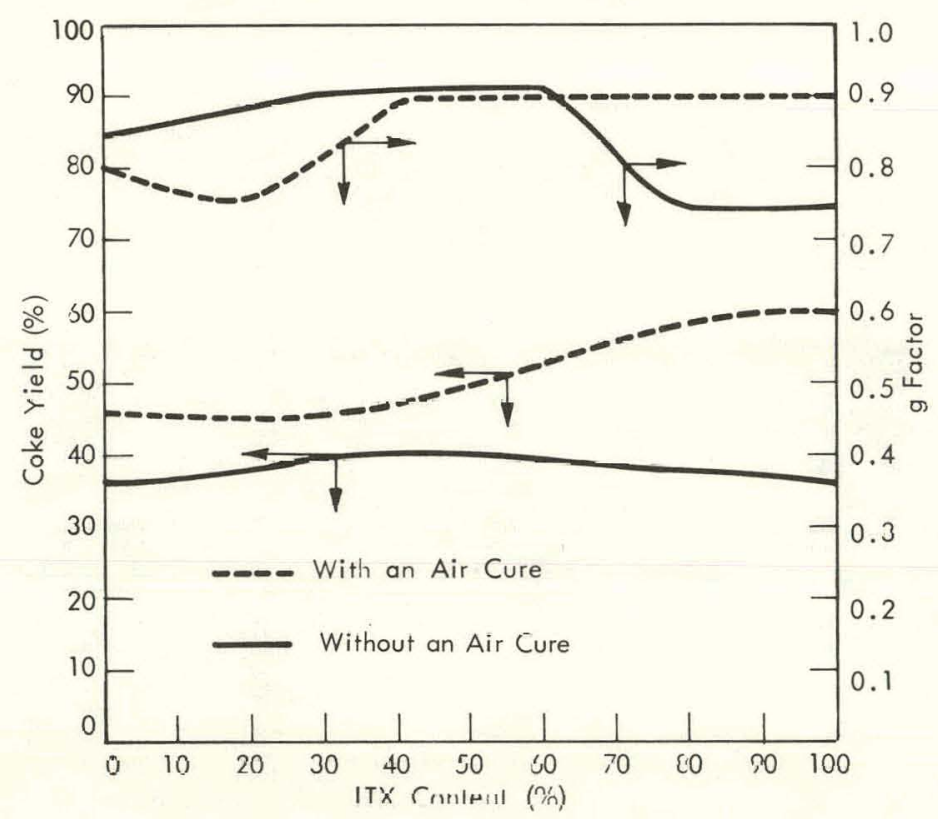

Figure 25. PROPERTIES OF CARBONS DERIVED FROM CINNAMYLIDENEINDENE/ISOTRUXENE MIXTURES AS FUNCTIONS OF THE ISOTRUXENE CONTENT.

Microstructures, shown in Figures 26 and 27, also reveal the transition in carbon crystallinity as the ITX content changed. Thus, air-cured samples from CAI/ITX mixtures change at ITX contents greater than 60 percent from a coarse-grain, more graphitic carbon to a fine-grain, less graphitic carbon (Figure 26), while the reverse transition occurs for uncured samples at ITX contents greater than 20 percent (Figure 27). 


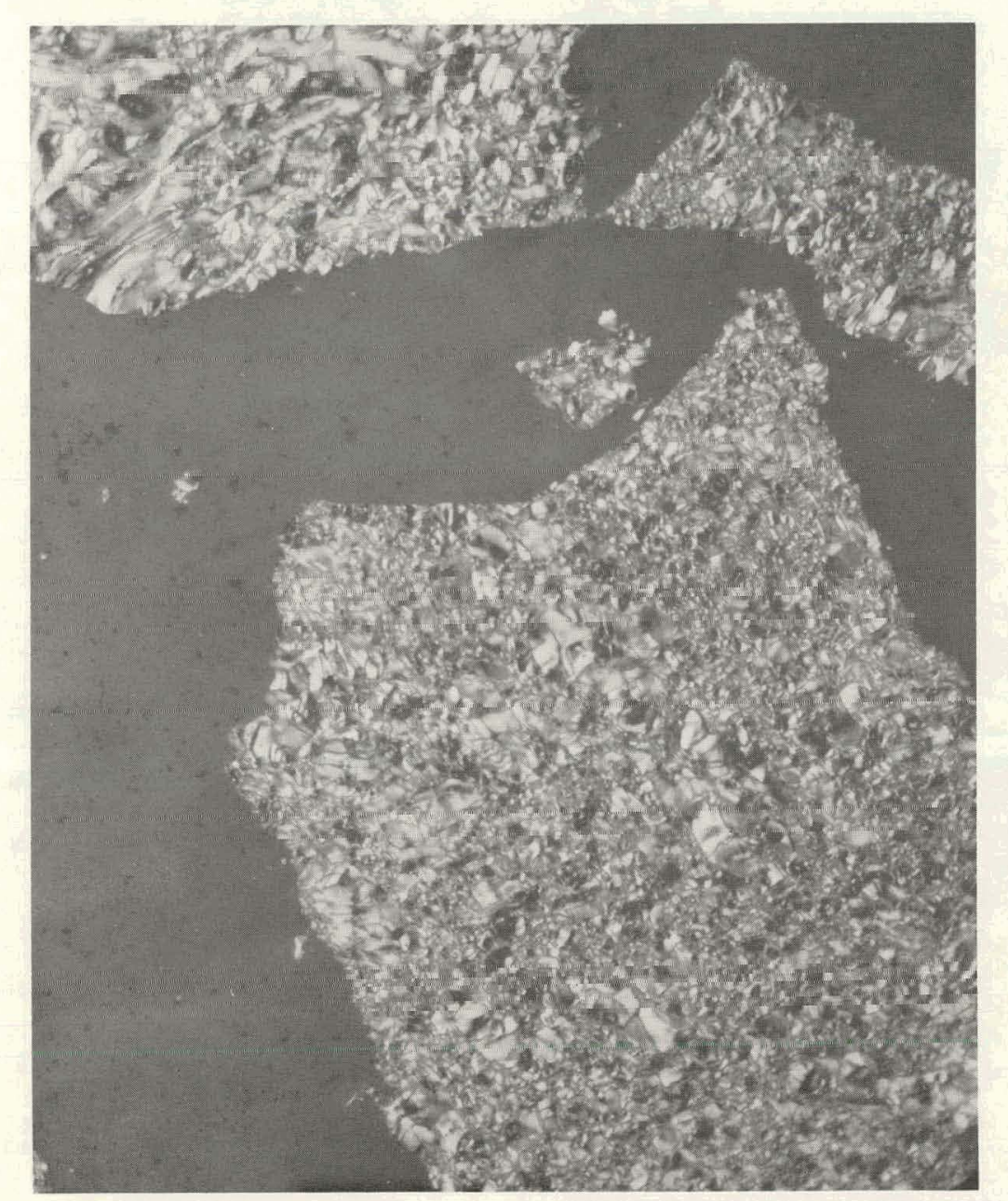

(a) $0 \%$ ITX.

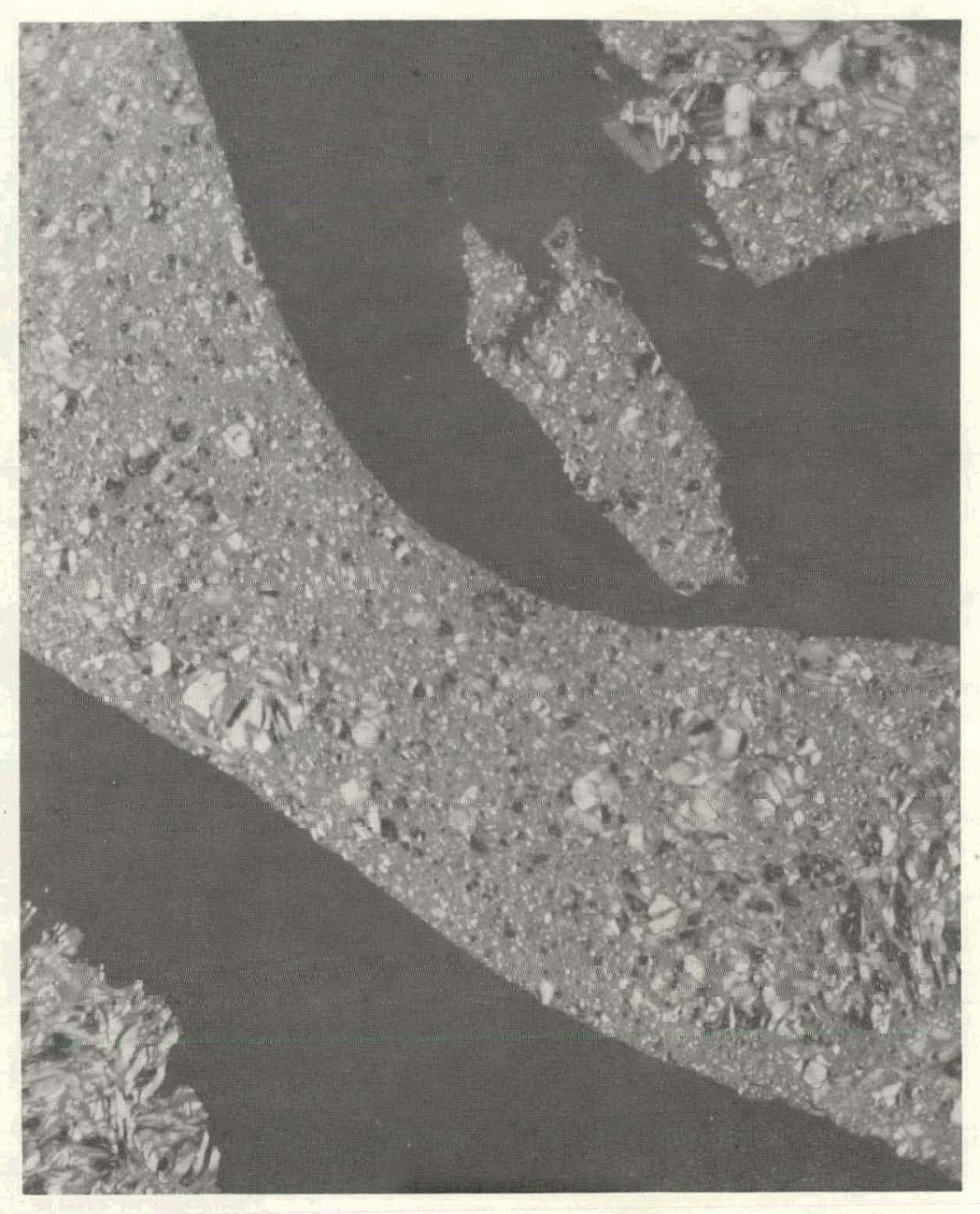

(b) $20 \%$ ITX.

G316-2

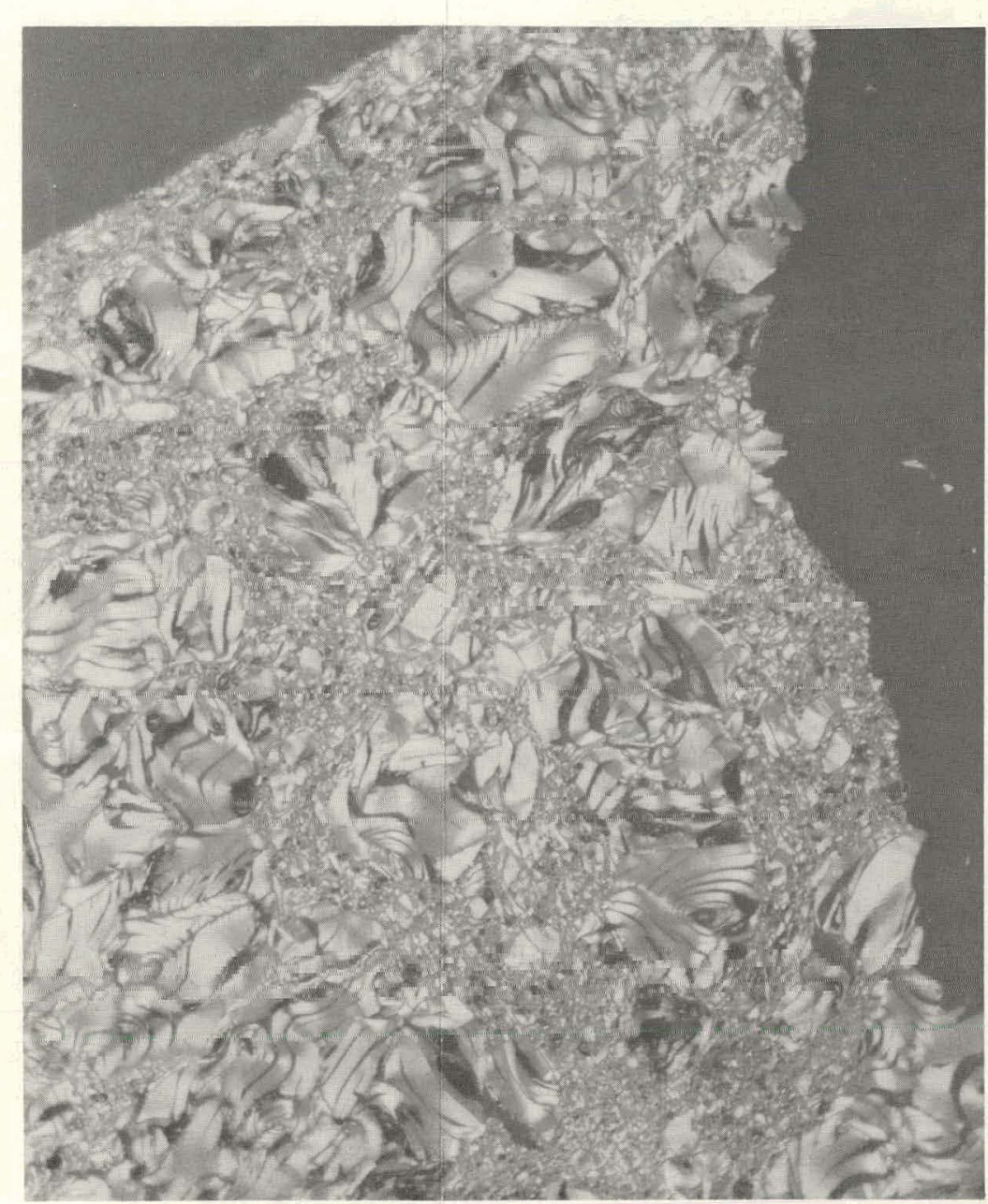

(c) $40 \%$ ITX.

G316-3

Figure 26. MICROSTRUCTURES OF CARBONS (AFTER $2,800^{\circ} \mathrm{C}$ ) DERIVED FROM AIR-CURED CINNAMYLIDENEINDENE/ISOTRUXENE MIXTURES. (Sensitive Tint; 250X) 


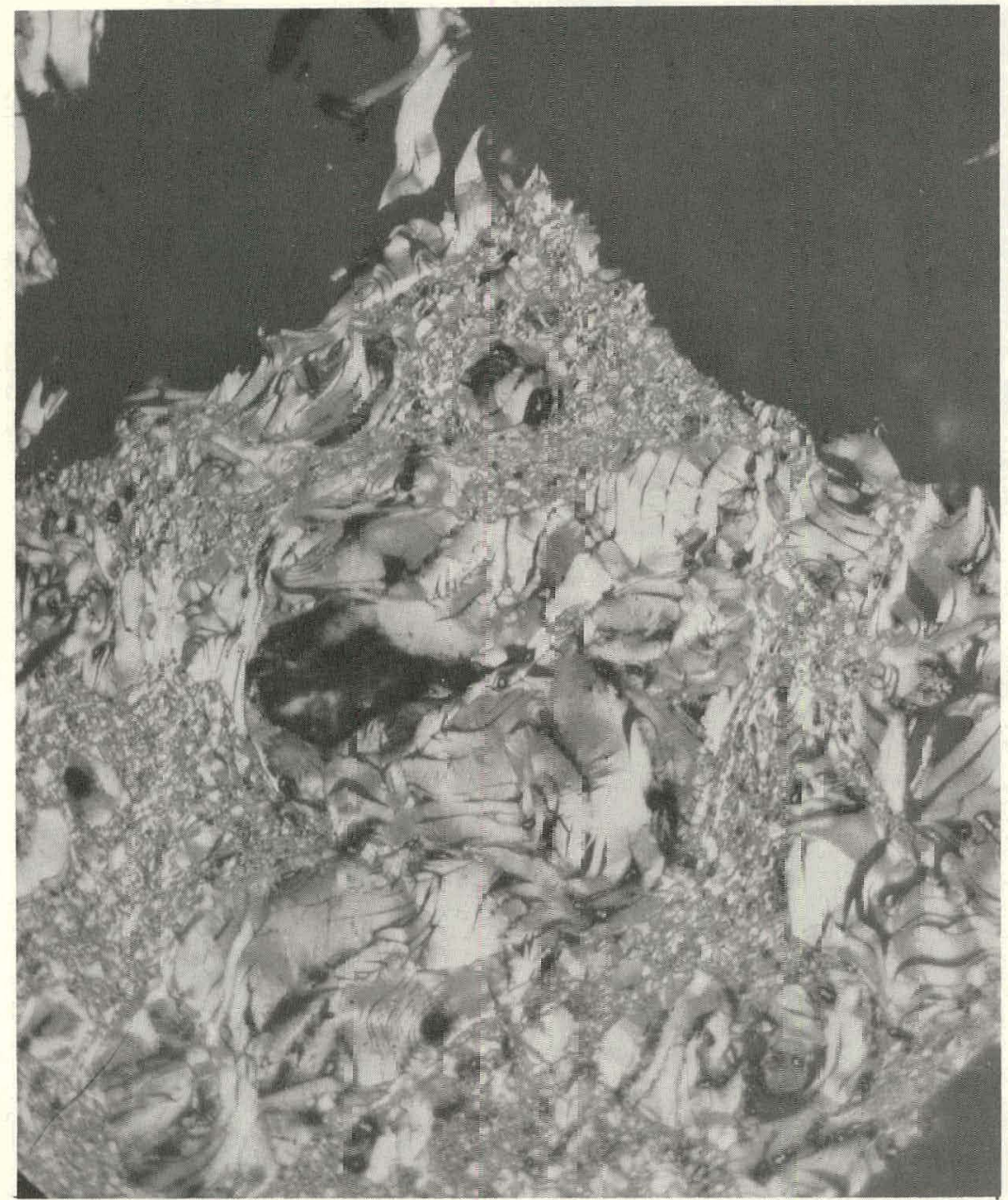

(a) $60 \%$ ITX.

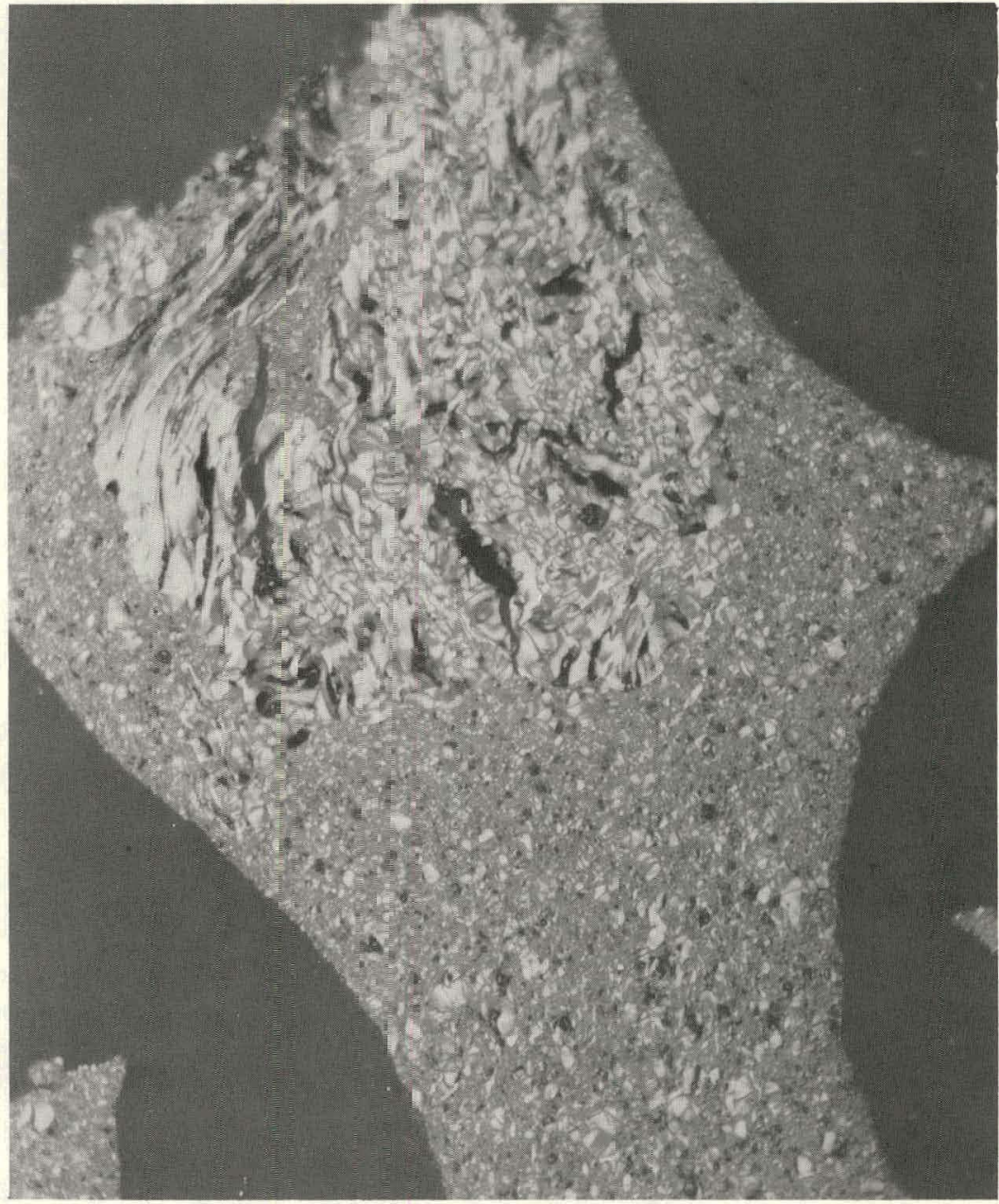

(b) $80 \%$ ITX.

Figure 27. MICROSTRUCTURES OF CARBONS (AFTER 2,8000 CI DERIVED FROM CINNAMYLIDENEINDENE'/ISOTRUXENE MIXTURES. (SENSitive Tint; 250X) 
In summary, air curing blends of CAI and ITX resulted in a gradual increase in coke yields as the ITX content in the blend increased, and an apparent minimum in crystallinity in the composition range corresponding to 0 to 40 percent ITX. Uncured samples yielded essentially constant coke-yield values and showed a decrease in crystallinity in the composition range corresponding to 60 to 80 percent ITX.

\section{CONCLUSIONS}

The data in this report show the versatility of acenaphthylene (ACN) and cinnamylideneindene (CAI) as carbon precursors. Thermal data show that a CAl polymer has adequate stability for extended periods at elevated temperatures as, for example, would be necessary for impregnating applications. Thermal data of an ACN-polymer show less potential for impregnating applications. Versatility of the precursors was demonstrated by the ability to modify properties of the $\mathrm{ACN}$ and $\mathrm{CAl}$-derived carbons by inclusion of various additives. These blends can be used to produce carbons that cover a wide range of crystalline properties. 


\section{REFERENCES}

(1) Smith, W. E., Napier, B., Jr, and Harper, W. L.; Preparation and Characterization of Hydrocarbon Derivatives of Indene, Y-1712; Union Carbide Corporation-Nuclear Division, Oak Ridge Y-12 Plant, Oak Ridge, Tennessee; April 21, 1970.

(2) Smith, W. E., Horne, O. J., Jr, Napier, B., Jr, Larson, E. A., and Harper, W. L.; Properties of Carbon Derived from Indene Compounds, Y-1790; Union Carbide Corporation-Nuclear Division, Oak Ridge Y-12 Plant, Oak Ridge, Tennessee; September $15,1971$.

(3) Wuest, H. M.; "'Isomerism of Benzfulvenes and Indenes", Ann, pp 415, 291 (1918).

(4) Muland, W.: "X-May Diffraction Studies on Carbon and Graphite", Chemistry and Physics of Carbon, 4, p 1, Edited by P. L. Walker, Jr; Marcel Dekker, Inc, New York (1908).

(5) Maire, J., and Mering, J.; Proceedings of the Fourth Carbon Conference, p 345; Pergamon Press, New York (1960).

(6) Horne, O. J., Jr, Smith, W. E., and Napier, B., Jr; Properties of Carbon Derived from Petroleum Pitches, Y-1875; Union Carbide Corporation-Nuclear Division, Oak Ridge Y-12 Plant, Oak Ridge, Tennessee; June 21, 1973. 


\section{ACKNOWLEDGEMENTS}

The authors wish to express their thanks to the Oak Ridge Y-12 Plant Analytical Laboratory for the analytical services rendered during this program and also to the Development Division Metallography Group for their efforts in preparing and photographing the samples for micrographic study. 


\section{DISTRIBUTION}

Aerojet General

Swope, L. S.

Aerospace Corporation - El Segundo

Blaes, H. M., II

McDonald, W. R.

Meyer, R. A.

Aerospace Corporation - Los Angeles

Barry, W. T.

MçClelland, J. D.

Army Materials and Mechanics

Mesearch Genter

Dignam, J. F.

Atomic Energy Commission - ORO

Hickman, H. D.

Zachry, D. S., Jr

Defense Nuclear Agency

Atkins, M./DDST

Jácksson, R.

Moulton, J./SPAS

Department of the Navy

Stoessl, L./SP-27201

Director of Defense Research and Engineering

Persh, J.

Fiber Materials, Inc.

Lachman, W.

General Electric Company

Hall, K.

Musikant, S.

Stover, E. R.

Gulf - General Atomic

Engle, G. B.
Lawrence Livermore Laboratory

Kruger, $\mathrm{H}$.

Lockheed Missile and Space Company

Vidoz, A.

Los Alamos Scientific Laboratory

Smith, M. C.

Taylor, J.

Williams, J. M.

McDonald-Douglas $\wedge$ stronautics

Company

Arne, C:

Eitman, D.

NASA - Ames Research Center

Lundell, J. H.

Naval Air Systems Command

Schmidt, R.

Naval Ordinance Laboratory

Barnet, F. R./Kaubek, F. J.

Gowen. L./Code 2302

Rester, Ũ. $\bar{U}$.

Naval Ordinance Systems Command

Kinna, M. A./ORD-0333A

Oak Ridge Gaseous Diffusion Plant

Wilcox, W. J., Jr

Winkel, R. A.

Oak Ridge National Laboratory

Bradley, R.

Eatherly, W. P.

Ferguson, D. E.

Horne, O. J. (15)

Scott, J. L.

Strehlow, R. A.

Weir, J. R. 
Oak Ridge Y-12 Plant

Ardary, Z. L.

Briscoe, O.W.

Burditt, R. B.

Burkhart, L. E.

Davis, R. M.

Denny, A.

Ebert, T. H.

Keith, Alvin

Kite, H. T.

Lambdin, $F$.

Lundin, M. I.

Marrow, G. B.

McLendon, J. D.

Mitchel, G. W.

Napier, B., Jr (5)

Napier, J. M.

Overholser, L. G.

Peterson, G. R.

Pollock, C. B.

Schreyer, J. M.

Smith, R. D.

Smith, W. E. (5)

Taylor, A. J.

Valentine, $K$.

Weathersby, W. E.

Williams, R. D.

Yaggi, W. J./Googin, J. M.

$Y-12$ Central Files (5)

Y-12 Central Files (master copy)

$Y-12$ Central Files (route)

Y-12 Central Files (Y-12RC)

Paducah Gaseous Diffusion Plant

Levin, R. W,

Penn State University

Walker, P. L., Jr
SAMSO

Green, G/RSF

Mentzer, D/RSSR

Shover, D/RSSE

Sandia - Albuquerque

Auerbach, I.

McDonald, J. E.

Peurifoy, R. L., Jr

Zimmerman, J. C.

Sandia - Livermore

Rychnovsky, R. E.

Union Carbide Corporation - Carbon Products Division

Browning, J. B.

Singer, $L$.

Townsend, H. N.

Union Carbide Corporation - Chemical and Plastics Division

Shecter, L.

University of Washington

Fishbach, D. B.

Wright-Patterson Air Force Base

Materne, H. A.

Pratt, C./MAAS

Schmidt, D./LNC

In addition, this report is distributed in accordance with the category UC-4, Chemistry, as given in the USAEC Standard Distribution Lists for Unclassified Scientific and Technical Reports, TID.4500. 